FEDERAL RESERVE BANK OF SAN FRANCISCO

WORKING PAPER SERIES

\title{
Mortgage Choice in the Housing Boom: Impacts of House Price Appreciation and Borrower Type
}

\author{
Frederick Furlong, \\ Federal Reserve Bank of San Francisco \\ Yelena Takhtamanova, \\ Federal Reserve Bank of San Francisco \\ David Lang, \\ Federal Reserve Bank of San Francisco
}

March 2014

Working Paper 2014-05

http://www.frbsf.org/economic-research/publications/working-papers/wp2014-05.pdf

The views in this paper are solely the responsibility of the authors and should not be interpreted as reflecting the views of the Federal Reserve Bank of San Francisco or the Board of Governors of the Federal Reserve System. 


\title{
MoRTgage CHOICE IN THE HoUSING BoOM: IMPACTS OF HOUSE PRICE APPRECIATION AND BORROWER TYPE
}

\author{
Frederick Furlong \\ Federal Reserve Bank of San Francisco \\ Yelena Takhtamanova \\ Federal Reserve Bank of San Francisco \\ David Lang \\ Federal Reserve Bank of San Francisco
}

January 2014 (updated March 2014)

\begin{abstract}
The U.S. housing boom during the first part of the past decade was marked by rapid house price appreciation and greater access to mortgage credit for lower credit-rated borrowers. The subsequent collapse of the housing market and the high default rates on residential mortgages raise the issue of whether the pace of house price appreciation and the mix of borrowers may have affected the influence of fundamentals in housing and mortgage markets. This paper examines that issue in connection with one aspect of mortgage financing, the choice among fixed-rate and adjustable-rate mortgages. This analysis is motivated in part by the increased use of adjustable-rate mortgage financing, notably among lower creditrated borrowers, during the peak of the housing boom. Based on analysis of a large sample of loan level data, we find strong evidence that house price appreciation dampened the influence of a number of fundamentals (mortgage pricing terms and other interest rate related metrics) that previous research finds to be important determinants of mortgage financing choices. With regard to the mix of borrowers, the evidence indicates that, while low risk-rated borrowers were affected on the margin more by house price appreciation, on balance those borrowers tended be at least as responsive to fundamentals as high riskrated borrowers. The higher propensity of low credit-rated borrowers to choose adjustable-rate financing compared with high credit-rated borrowers in the housing boom appears to have been related to borrower credit risk metrics. Given the evidence related to loan pricing terms, other interest rate metrics and fixed effects, the relation of credit risk to mortgage financing choice seems more consistent with considerations such as credit constraints, risk preferences, and mortgage tenor than just a systematic lack of financial sophistication among higher credit risk borrowers.
\end{abstract}

JEL Codes: D1, G11, G21, R2

Keywords: mortgage choice, mortgage contracts, household finance, fixed-rate, adjustable-rate

The views in this paper are solely the responsibility of the authors and should not be interpreted as reflecting the views of the Federal Reserve Bank of San Francisco or the Board of Governors of the Federal Reserve System. 


\section{Introduction}

The U.S. housing boom during the first part of the past decade was marked by rapid house price appreciation and easing of credit standards and loan terms on residential mortgages. This combination facilitated an expansion of mortgage credit availability, especially for borrowers with lower credit ratings. The subsequent collapse of the housing market and the high default rates on residential mortgages raise the issue of whether the pace of house price appreciation and the mix of borrowers may have affected the influence of fundamentals in housing and mortgage markets.

This paper examines that issue in connection with one aspect of mortgage financing, the choice among fixed-rate and adjustable-rate mortgages. In particular, for the housing boom period, we examine the relationship of house price appreciation to mortgage choice, emphasizing the effects on sensitivity of borrowers to mortgage pricing terms (margins on fixed- and adjustable-rate mortgages) and other interest-rate-related metrics (such as the term structure of short-term rates, interest rate volatility, and term premium), which previous research finds to be important in the mortgage financing choice between fixed- and adjustable-rate loans. In addition, in the aftermath of the recent mortgage crisis commentators pointed to the high propensity of vulnerable or less financially sophisticated households to select ARM financing. Accordingly, we investigate whether decisions of borrowers with lower credit ratings might have been influenced less by fundamentals. We also present evidence for different credit risk cohorts related to differences in their sensitivity to mortgage pricing terms and interest rate metrics as well as to house price appreciation.

Previous research consistently finds that mortgage pricing terms and other interest-raterelated metrics are important determinants of mortgage financing choice (see, for example, Dhillon et al. 1987, Vickery 2007, Koijen et al. 2009, and Krainer 2010). Theoretical modeling of mortgage choice and empirical evidence also indicate that house price appreciation can affect borrowers' selection among different fixed- and adjustable-rate mortgages, with higher appreciation favoring adjustable-rate mortgages (see, for example, Elliehausen and Hwang 2010 and Krainer 2010). Our paper adds to the literature on mortgage financing choice in two important dimensions, using cross-section time series data for local housing markets for the period 2001 through 2007. First, we examine the interaction between house price appreciation and mortgage loan pricing terms along with other interest rate-related metrics-specifically, term 
premium, the change in expected short-term interest rates, and interest rate volatility. Second, we compare the sensitivities of mortgage financing choice to mortgage pricing terms and interest-rate-related metrics and the effects of house price appreciation for the different credit risk groups.

Regarding the interaction of house price appreciation with other determinants of mortgage financing choice during the housing boom, to the extent there was a housing price bubble, decisions regarding buying and financing real estate could be expected to be less systematically linked to traditional determinants of mortgage choice in general. Shiller (2013), for example, argues that "the radical shifts in housing prices in recent years were caused mainly by investor-induced speculation." The unprecedented increases in price-to-rent-ratios across a large number of housing markets (see for example, Shiller 2007) were suggestive of a potential disconnect between fundamentals and the housing sector during the boom were). Wheaton and Nechayev (2008), using cross-section time series data for a sample of 10 metropolitan markets with published Case-Schiller-Weiss price data, find that increases in housing demand related to fundamentals such as population, income growth, and the decline in interest rates could not explain the increase in housing prices in the years running up to 2005. Barlevy and Fisher (2011) also present evidence supporting the view that the recent boom-bust in the housing market was associated with a speculative bubble in housing markets.

Some researchers, on the other hand, question whether there was widespread ex ante misalignment of house prices during the housing boom (Smith and Smith 2006). However, even without ex ante misalignment of house prices, rapid price gains still could have affected mortgage choice through expectations of future gains. In this regard, other researchers argue that expectations of rising house prices (and an accompanying discounted probability of sizeable house price declines) rationalize the decisions of borrowers, investors, and intermediaries during the housing boom (Gerardi et al. 2008, and Foote et al. 2012). In that context of elevated expectation for house price appreciation, reduced sensitivity of mortgage choice to mortgage pricing and other interest-rate-related term could be consistent with rational consumer choice. Campbell and Cocco (2003), for example, show that expected residential (mortgage) tenure can affect mortgage financing choices, with a shorter expected tenure favoring ARMs. The prospects for future appreciation may have been viewed as providing opportunities for accumulating home equity and reselling a property or potentially refinancing at more favorable 
terms in a relatively short period of time, even for borrowers expecting to stay in their house for an extended period. Such an influence of the pace of house price appreciation on mortgage choice could have been relevant for home buyers in general, but may have been especially important for more financially constrained borrowers with poorer credit ratings.

Also relevant to mortgage financing choices across risk cohorts, Campbell and Cocco (2003) present a model in which attitudes toward risk and borrowing constraints can affect mortgage choice. The empirical analysis of Coulibaly and Li (2007) also shows that attitudes toward risk can affect the sensitivity of the mortgage choice decisions to loan pricing and the significance of income volatility and affordability factors to those decisions. To the extent that factors impacting attitudes toward risk such as the expected cost of default are less important for borrowers with already low credit ratings, the relative importance of the traditional determinants of loan-type choices may differ among borrower cohorts with different credit ratings.

Finally, other studies suggest that the degree of financial literacy among borrowers may affect mortgage choice. Bucks and Pence (2008) find that borrowers opting for ARMs appear more likely to underestimate or to not know how much interest rates on their loans could change. Thus, differences in financial literacy among borrower cohorts with different credit ratings could affect the sensitivities of financing choice to loan pricing and other interest-rate-related terms.

The rest of the paper is organized as follows: Section 2 provides an overview of the changes in house prices and mortgage choices during the housing boom; Section 3 presents a selected literature review related to mortgage choice; Section 4 discusses empirical methodology used in this study; Section 5 focuses on the data used in this study; Section 6 discusses the empirical results; and Section 7 summarizes the main conclusions.

\section{House prices and mortgage choices during the housing boom}

House price appreciation in the United States began picking up steam in the second part of the 1990s, after lagging gains in rents in the first part of that decade (Figure 1). In the late 1990s and early 2000s the pace of house price appreciation accelerated, with the increase in one national index averaging about 10 percent at an annual rate over the period 2000 through 2003, outpacing gains in rental rates and pushing up price-to-rent ratios. In late 2003, the pace of house price appreciation jumped up further, averaging nearly 16 percent at an annual rate for the 
2004 to 2005 period and leaving house price-to-rent ratios at historic highs. House prices peaked in the first part of 2006 and then drifted lower before plunging starting in 2007.

The increase in the demand for housing was reflected in a pickup in home sales and an increase in the homeownership rate starting in the mid-1990s and continuing into 2005 (Figure 2). During that period, the pace of home sales accelerated noticeably after 2002 when house prices were rapidly appreciating. With regard to homeownership, Doms and Krainer (2007) show that the rise in ownership rates was most notable among households that are traditionally cash constrained. In particular, they show the homeownership rate rose among young and lowincome households, borrowers less likely to have high credit ratings. They argue that changes in mortgage financing including lenders' accepting higher loan-to-value ratios and the availability of ARMs facilitated the extension of mortgage credit to these borrowers who are less likely to have high credit ratings.

With regard to mortgage choice, in the United States, FRMs traditionally have been the more popular loan choice. ${ }^{1}$ Since the early 1980s, however, the mix of FRMs and ARMs among new loans has fluctuated dramatically. ${ }^{2}$ Figure 3 shows the long history for the share of ARM loans from Freddie Mac Primary Mortgage Survey along with the ARM share from the sample drawn from the LPS Analytics data used in this study. For both series, ARMs again gained popularity during the housing boom. The relative popularity of ARMs was especially notable in the period when house price appreciation was the most rapid. Data from the sample used in this study show that during the peak of the housing boom the share of mortgage originations accounted for by ARMs was highest among borrowers with lower risk ratings, as measured by FICO $^{3}$ scores (Figure 4).

There are several types of ARM loans. For a basic ARM, an initial rate is set as a spread to a benchmark rate such the one-year Treasury rate. The interest rate then adjusts periodically

\footnotetext{
${ }^{1}$ The overwhelming majority of FRMs involve the payment of interest and principal. In the sample for this study about 98 percent of FRM payments included principal and interest and 2 percent allowed interest-only payments for a period of time.

${ }^{2}$ U.S. Congress passed the Alternative Mortgage Transactions Parity Act (AMTPA) in 1982, allowing non-federally chartered mortgage lenders to offer adjustable rate mortgages (ARMs). Prior to that, lenders were mostly constrained to offer fixed-rate mortgages (FRMs). The popularity of ARMs grew over time and peaked in the mid1990s. In the wake of the housing boom, the share of ARMs dropped dramatically (see Krainer 2010 and Moench et al. 2010, for instance).

${ }^{3}$ FICO is an acronym for the Fair Isaac Corporation. Credit scores are designed to measure the risk of default by taking into account various factors in a person's financial history.
} 
with changes in the benchmark, often with limits on the size of the periodic adjustments and the total adjustment over the life of the loan. A popular choice during the housing boom was the hybrid ARM. An example of such an ARM is the so-called 2-28 ARM, which is a 30-year mortgage where the interest rate remains fixed for two years and can adjust periodically during the remaining years. As pointed out in previous studies, these loans tended to be paid down (refinanced) ahead of the specified adjustable rate period (see, for example, Demyanyk 2009). ${ }^{4}$ Option ARMs are another financing choice. In these arrangements, the borrower chooses among several payment options each month. Those options typically include (1) a minimum payment which keeps the loan current (but with negative amortization of unpaid interest), (2) an interestonly payment, and (3) a traditional payment of principal and interest. Option ARMs were introduced in the 1980s, but gained popularity in the mid-2000s, especially in states where home prices were rising rapidly.

\section{Residential Mortgage Financing Choices, Brief Literature Review}

A critical part of the decision in financing a home is the choice of the type of mortgage loan. In the broadest sense, loans can be separated into fixed-rate mortgages (FRMs) and adjustable-rate mortgages (ARMs), with the latter consisting of non-option adjustable-rate mortgages and option adjustable-rate mortgages. Past research suggests that the type of mortgage financing selected by a borrower should be affected by loan terms, market conditions, and borrower characteristics. Loan terms encompass both price and non-price features. The main pricing components typically considered in the literature are own initial interest rates on FRMs and ARMs. Key non-price loan terms include loan-to-value (LTV) ratios, prepayment penalties, amortization period, and purpose of the loan (purchase vs. refinance). Market conditions considered in past research include the shape of the yield curve or, more recently, estimates of interest rate term premiums, interest rate volatility, house price appreciation, volatility of house price appreciation, and depth of securitization markets. Borrower characteristics include credit ratings, income, and various demographic characteristics. Other borrower characteristics suggested by theoretical models include attitudes toward risk, variability

\footnotetext{
${ }^{4}$ Among the non-option ARMs in the sample for this study, about 40 percent are identified as allowing interest-only payments for some period of time.
} 
of income, expected cost of default, degree of financial constraint, and mobility (probability of moving—expected mortgage tenure). ${ }^{5}$

The empirical literature on mortgage choice finds that loan pricing terms play a dominant role in mortgage choice. Early work includes Baesel and Biger (1980) and Statman (1982). The work of Dhillon et al. (1987) was the first to examine empirically the impact of both pricing and borrower characteristics on the choice of the mortgage contract. Based on a small micro-data set covering a short sample period, that study finds that the rate on FRMs and the margin on ARMs were important in the mortgage choice decision, while borrower characteristics, in general, were not significant determinants of the choice. In particular higher interest rates on FRMs and smaller margins favored the choice of ARMs.

Results from other early studies such as Brueckner and Follian (1988), using borrower (loan) level data, and Nothaft and Wang (1992), using aggregated time series data for the U.S. and selected sub-regions, support findings that higher fixed-interest rates on mortgages tend to lead to higher shares of borrowers choosing ARMs. For the own pricing of ARMs, these studies included the difference (spread) between FRM interest rates and ARM interest rates. The findings show that larger spreads favor the choice of ARMs.

Subsequent studies using larger data sets covering longer time periods also find that loan pricing terms are significant determinants of mortgage choice (Jones and Miller 1995, Coulibaly and Li 2009, Krainer 2010, Moench et al. 2010). Again, these studies find a positive relation between the level of interest on FRMs and the propensity for borrowers to opt for ARMs, and a positive relation between the FRM-ARM spread and the choice of ARMs.

As noted by Nothaft and Wang (1992), one interpretation of the positive relation between fixed mortgage rates and the choice of ARMS is that it reflects borrowing constraints. At higher interest rates, it is less likely that a borrower with a given income (and down payment) would qualify for a mortgage. To the extent that an affordability/qualification explanation holds, an easing of the credit supply related to underwriting standards for qualifying borrowers in an environment of rising house prices could weaken the empirical relationship between ARM choice and the level of interest rates.

\footnotetext{
${ }^{5}$ Campbell and Cocco (2003), Alm and Follain (1987), and Brueckner (1986).
} 
The previous research also expanded the set of explanatory variables reflecting market conditions (such as the difference between short- and long-term rates on alternative investments and the secondary market securitization rate of ARMs) in examining mortgage financing choices (see for example Dhillon et al. 1987 and Jones and Miller 1995). Recent work by Coulibaly and $\mathrm{Li}$ (2009) considered an expanded set of borrower characteristics using the Survey of Consumer Finances, which contains detailed data on household finances, demographics, and mortgages. Relying on these self-reported mortgage choice characteristics, that study finds that loan pricing variables and other contract terms are important considerations in mortgage choice, along with measures of affordability and financial stress.

Coulibaly and Li (2009) also find empirical support for the hypothesis that attitudes toward risk are important to mortgage financing choice, consistent with Campbell and Cocco (2003). The former find FRM financing is preferred by more risk-averse borrowers, those with more uncertain income, and those less likely to move. They also find mortgage pricing terms tend to have less influence on mortgage financing choices for less risk-averse borrowers.

Important advances in modeling mortgage choice and the treatment of mortgage pricing terms and market factors have been made in recent research. Koijen et al. (2009) make a notable contribution by formally demonstrating the importance of interest rate term premiums in mortgage choice. As discussed below, longer-horizon term premiums should be reflected in interest rates on fixed-rate mortgages. In their empirical analysis, Koijen et al. (2009), using macro-level data as well as loan-level data aggregated over several groupings, provide evidence that higher long-term interest rate term premiums increase the likelihood borrowers will opt for ARM financing. However, in their empirical analysis, they do not include other components of mortgage pricing terms (such as the margins on fixed-rate mortgages after accounting for term premiums and margins on adjustable-rate mortgages) or market interest rate metrics such as expected interest rates and measures of interest rate risk.

The two latter components are included in the theoretical analysis presented by Elliehausen and Hwang (2010), along with the margin on adjustable-rate mortgages. In their model, expected future short-term interest rates compared to current short-term interest rates and interest rate uncertainty both affect borrower's choice between fixed-rate and adjustable-rate mortgages. Higher expected future short rates (relative to current rates) increase the likelihood of borrowers preferring ARM financing (for a given house value). On the other hand, higher 
interest rate risk tends to lead a borrower to opt for fixed-rate financing. The latter effect reflects the increase in the margin on adjustable-rate mortgages due to the lender's concern about future defaults from borrowers owing to "payment shock."6

In Elliehausen and Hwang (2010) house price appreciation also can affect the choice between FRM and ARM financing. While the main focus of that study is the interaction of loanto-value of mortgages and expected interest rates and interest rate volatility, their theoretical model also predicts that that higher expected house price appreciation should increase the likelihood of a borrower opting for ARM financing. Specifically, the model says that higher expected house price appreciation increases the loan size level below which ARM contracts are preferable to FRM loans. The empirical analysis in their paper, using loan level data for subprime borrowers, supports the implication of their model regarding house price appreciation and loan choice. Other studies, such as Krainer (2010), also find a relation between house price appreciation and mortgage choice. That study uses loan level data that include conforming loans to non-subprime borrowers and finds that higher house price appreciation is associated with a higher probability of borrowers opting for ARM financing.

\section{Empirical Methodology}

\subsection{Empirical Model Specification}

We model the mortgage choice decision using a multinomial probit model,

$$
P\left(I_{i}=m\right)=P\left(U_{i m}>U_{i j}\right) \text {, for } \mathrm{m}=(1,2,3), \mathrm{j}=(1,2,3) \text { and } \mathrm{j} \neq \mathrm{m} \text {, }
$$

where $U_{i m}$ represents the utility for borrower $i$ opting for mortgage choice $m$. The options for $m$ are three non-ordered choices for mortgage financing: fixed-rate mortgage, adjustable rate mortgage (without interest rate option), and option adjustable-rate mortgage. Following previous research on the determinants of mortgage financing choices, $I_{i}$ is expressed as a function of loan terms, market conditions, and borrower characteristics.

\footnotetext{
${ }^{6}$ Elliehausen and Hwang (2010) assume borrowers are more impatient than lenders.
} 
$I_{i}=f\left(\right.$ Mortgage $\_$Terms, Other_Interest_Rate_Metrics,

Housing_Market_Conditons, Borrower_Characteristics), where

Mortgage Terms

$$
\begin{aligned}
& F R_{i}=\text { Fixed-Rate Mortgage Interest Rate } \\
& A R_{i}=\text { Adjustable-Rate Mortgage Interest Rate } \\
& L T V_{i}=\text { Loan-to-Value (of the property) } \\
& \text { Conf }_{i}=\text { Confirming Loan Size }
\end{aligned}
$$

Other Interest Rate Metrics

$$
\begin{aligned}
& L R=\text { Long-term Risk-free Interest Rate } \\
& S R=\text { Short-term Risk-free Interest Rate } \\
& T P=\text { Term Premium on } L R \\
& E\left(S R_{n}\right)=\text { Expected Average Risk-free Short-term Interest Rate over n periods } \\
& \text { Rvol = Interest Rate Volatility }
\end{aligned}
$$

Housing Market Conditions

$$
\begin{aligned}
& \text { ExHPA }_{i}=\text { Expected House Price Appreciation } \\
& \text { HPvol }_{i}=\text { House price uncertainty }
\end{aligned}
$$

Borrower Characteristics

$$
\begin{aligned}
& C R R_{i}=\text { Credit Risk Rating } \\
& \text { Sub }_{i}=\text { Lender Subprime Designation } \\
& \text { Doc }_{i}=\text { Degree of Loan Documentation } \\
& \text { Inc }_{i}=\text { Income } \\
& \text { IncR }_{i}=\text { Income Risk }
\end{aligned}
$$

In specifying the empirical model, we use the following relationships, where subscript $i$ refers to the individual borrower:

$$
\begin{aligned}
& L R=E\left(S R_{x}\right)+T P \\
& \operatorname{TermStr}_{x}=E\left(S R_{x}\right)-S R \\
& F R_{i}=L R+f r m+f_{r} m_{i} \\
& f r m=F R-L R \\
& E(A R)_{i}=E\left(S R_{y}\right)+\text { arm }+\operatorname{arm}_{i} \\
& \operatorname{arm}=A R-S R
\end{aligned}
$$


The risk-free long-term rate is a function of the expected short-term rates over $x$ periods corresponding to the expected life of a fixed-rate mortgage and the term premium. For the other components of the mortgage rates, frm is the average margin on a conventional 30-year mortgage and $\mathrm{frm}_{i}$ is the borrower-specific component of the margin on a fixed-rate mortgage. The expected adjustable rate for the borrower is a function of the expected short-term rates over the expected life of the mortgage of length $y$ periods. The term arm is the average margin on an adjustable-rate mortgage and $\operatorname{arm}_{i}$ is the borrower specific component of the margin on an adjustable rate mortgage. ${ }^{7}$ The borrower specific margins can be positive, negative or zero and are functions of the size of the loan, regional market conditions, non-price loan terms, and borrower characteristics.

The indicator of mortgage choice then is expressed as:

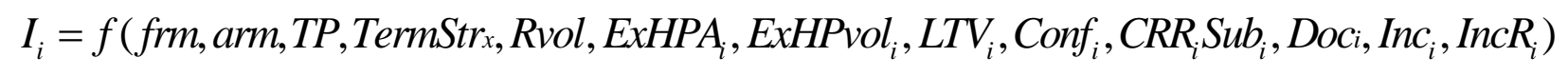

The terms frm and arm should reflect general credit supply conditions in the mortgage market. While the overall margins for a borrower will depend on regional market and individual factors, higher values of frm should increase the likelihood of borrowers opting for an ARM, while higher values of arm should decrease the likelihood of borrowers choosing ARM financing.

The term premium, $T P$, represents the adjustment to the yield on an instrument that investors require to commit to holding a long-term debt instead of a series of shorter-term instruments. ${ }^{8}$ With regard to mortgage financing, the effect of the term premium on a borrower's financing choice will depend in part on the borrower's expected prepayment (or refinancing) horizon. For example, Campbell and Cocco (2003) show that borrowers with low mobility will prefer FRM financing. For a given distribution of expected prepayment horizons among borrowers, then, a higher term premium would be expected to increase the likelihood that borrowers would opt for ARM financing. To the extent that term premiums tend to be positive,

\footnotetext{
${ }^{7}$ For an individual adjustable-rate mortgage, the effective margin over the relevant benchmark rate can differ from the initial margin at origination, owing to so-called teaser rates.

${ }^{8}$ Koijen, Van Hemert and Van Nieuwerburgh (2009) show that term structure variables play an important role in mortgage choice.
} 
this dimension of mortgage terms also could affect the mortgage financing choice through the affordability channel.

The term structure of short-term rates could affect mortgage choice through different channels. First, to the extent the expected tenor $(y)$ of an adjustable rate mortgages is less than the expected tenor $(x)$ for a fixed-rate mortgage, say, owing to higher mobility a la Campbell and Cocco (2003), then the term structure of short-term rates could affect a borrower's choice of financing. If interest rates were expected to rise (fall) over time, $E\left(S R_{x}\right)$ would be greater (less) than $\mathrm{E}\left(S R_{y}\right)$. As noted earlier, Elliehausen and Hwang (2010) present a model in which the term structure of short-term rates can affect mortgage choice through another channel. In their model, a steeper slope of expected short-term rates tends to increase the current payment on a fixed-rate mortgage more than for a comparable adjustable-rate mortgage. In that model, borrowers are assumed to be less patient than lenders, so that the difference in the payment profile implies a positive relation between the term structure of short-term interest rates and borrowers' choice of adjustable-rate financing. ${ }^{9}$

With regard to the volatility of interest rates, Campbell and Cocco (2003) show that attitudes toward risk can affect mortgage choice, with more risk-averse borrowers tending to favor fixed-rate financing. Elliehausen and Hwang (2010) also argue that higher interest rate risk ( $R v o l)$ tends to lead a borrower to opt for fixed-rate financing. Higher interest rate volatility increases expected losses for the lender. Accordingly the lender increases the margin on adjustable-rate mortgages due to concern about future defaults owing to borrower "payment shock." This tends to reduce the appeal of adjustable-rate financing for the borrower because the option value of default for the borrower, who is assumed to be less patient, is less than the lender's required adjustment to the margin on an adjustable-rate mortgage.

Previous studies find that the pace of house price appreciation is positively related to the probability of choosing an ARM in general. In this regard, Elliehausen and Hwang (2010) show that higher expected house price appreciation increases the likelihood of a borrower opting for ARM financing, for a given loan-to-value (LTV) ratio. In the context of our expression for $I_{i}$,

\footnotetext{
${ }^{9}$ In the empirical analysis, Elliehausen and Hwang (2010) use a "term spread" measure related to the slope of the yield curve, which combines the term premium and the term structure of short-term interest rates. We treat these two components separately.
} 
higher house price appreciation would lower the value of $\mathrm{arm}_{i}$ due to the lender facing a lower probability of default by the borrower.

Elliehausen and Hwang (2010) also show that house price volatility works to reduce the attractiveness of ARM financing. In their analysis, higher house price volatility raises $\operatorname{arm}_{i}$ and lowers the likelihood of a borrower choosing ARM financing. The expected effect of LTV on mortgage is a bit complicated. Financially constrained borrowers might find it easier to qualify in terms of income for ARM financing, since initial rates on such loans typically are lower than on fixed- rate mortgages. ${ }^{10}$ As noted earlier, Doms and Krainer (2007) find that during the housing boom the rise in ownership rates was most notable among households that are traditionally cash constrained. In particular, they show the homeownership rate rose among young and low-income households, borrowers less likely to have high credit ratings. More generally, financing constraints would be expected to be more prevalent among borrowers with lower credit ratings. Such borrowers are more likely to be constrained in terms of the size of a down payment and, thus, tend to favor higher LTVs. Higher LTVS then may be associated with a higher propensity to choose ARM financing.

Abstracting from financial constraints, Elliehausen and Hwang (2010) present a model in which LTV interacts with other determinants of mortgage financing choice. In the context of our expression for $I_{i}$, from the Elliehausen and Hwang (2010) model, a higher value of Term_Str $x_{x}$ tends to increase the LTV for which ARM financing is preferred to FRM financing. On the other hand, an increase in interest rate volatility reduces the $L T V$ at which ARM financing is preferred. In the empirical analysis, we allowed for interaction between an indicator of high LTV with Term_Strx and Rvol. We identify high loan-to-value of first-lien mortgages as those with LTV greater than or equal to 80 percent. Coefficient on $\operatorname{TermStr}_{x}$ and Rvol are estimated separately for higher and lower loan-to-value mortgages. ${ }^{11}$

For the other nonprice term, Conf indicates whether the mortgage conforms to the size limits for mortgages to qualify for securitization by federal government-sponsored enterprises (GSEs). Previous research shows that interest rates on fixed-rate mortgages are lower on loans

\footnotetext{
${ }^{10}$ In the theoretical model from Campbell and Cocco (2003), risk-averse, financially constrained borrowers are more likely to opt for ARM financing.

11 The results without the interaction terms do not change the conclusions from our analysis.
} 
meeting the conforming standards compared to otherwise comparable larger loans (see for example, Passmore et al. 2007). In addition, Vickery (2007) shows that the market share of ARMs discontinuously shifts upwards at the conforming loan limit. The explanation is the shift is due to borrowers responding to a shift in relative interest rates on ARMs compared with FRMs. It is expected that borrowers able to finance with loans that conforms to GSE size limits would be more likely to choose a fixed-rate mortgage.

\subsection{Interaction between house price appreciation and interest-rate-related terms}

Previous studies find that the pace of house price appreciation is positively related to the probability of choosing an ARM in general. Thus, house price appreciation and house price volatility enter directly in our specification. Central to our analysis also is how the pace of house price appreciation might alter the consideration borrowers give to interest-rate-related terms when choosing the type of mortgage financing. In our analysis we test for such effects by interacting house price appreciation with what we refer to as "the fundamentals": mortgage pricing terms, arm and frm, and the other interest rate metrics, TP, TermStrx, and Rvol. To the extent that rapid house price gains dampen the influence of fundamentals in mortgage borrowers' financing choices, we would expect the sensitivity of the mortgage financing choice to the loan pricing and interest rate terms to diminish with an increase in the pace of house price appreciation in a market.

Why might one expect house price appreciation to erode the influence of fundamentals on mortgage choice? One potential factor behind such dampening effects could be a general disconnect with fundamentals in a housing bubble. A second is a delinking of the expected tenor of mortgage and the expected tenor of homeownership. As noted earlier, while expectations regarding house prices appreciation in the boom may have been too optimistic, given those expectations, finding that house price appreciation altered the influence of interest-rate-related determinants of mortgage choice still would be consistent with mortgage choice models. For example, the implications of borrower mobility in Campbell and Cocco (2013) can apply more generally to expected time to repayment of a mortgage. With little or no change in house prices, the expectations about moving or terminating a mortgage would be related to life-cycle events such as illness, retirement, job changes, unemployment, etc. 
However, that might change when house prices are rising rapidly. Historically, the past change in house prices was a good predictor of future changes, so increases in house prices in the first part of the last decade likely fed expectations of further appreciation. The prospects for future appreciation may have been viewed as providing opportunities for accumulating home equity and refinancing in a few years, even if the borrower did not plan to move. Alternatively, some purchasers looking to "flip" houses would have had very short expected homeownership tenure. In both cases, the expected time to paying off the mortgage among borrowers would be shortened, leading to higher ARM shares for given levels of the term premium, expected interest rates, and mortgage margins. The shorter effective degree of mobility (higher propensity to repay) also could alter the effects of interest rate volatility on mortgage choice.

\subsection{Credit rating and mortgage financing choice}

With regard to loan choice across risk cohorts, Campbell and Cocco (2003) present a model in which attitudes toward risk and borrowing constraints can affect mortgage choice. Coulibaly and Li (2009) find empirical evidence confirming that financially constrained borrowers tend to favor ARM financing. As suggested above, financial constraints would be expected to be more binding among borrowers with lower credit risk ratings, so that a lower $C R R_{i}$ would be expected to increase the likelihood of a borrower using ARM financing. Similarly, borrowers with separate loan-originator designation of subprime (sub) would be expected to favor ARM financing. As noted earlier, Coulibaly and Li (2009) find that attitudes toward risk can affect the sensitivity of mortgage-type choice decisions to loan pricing and the significance of income volatility and affordability factors to those decisions. To the extent that factors impacting attitudes toward risk such as the expected cost of default are less for borrowers with already low credit ratings, the relative importance of the traditional determinants of loantype choices may differ among borrower cohorts with different credit ratings.

Other studies suggest that the degree of financial literacy among borrowers may affect mortgage choice. Buck and Pence (2008) find that borrowers opting for ARMs appear more likely to underestimate or to not know how much interest rates on their loans could change. Difference in financial literacy among borrower cohorts with different credit ratings could also affect the sensitivity to loan pricing in choice of types of loans. In the empirical analysis we also 
include a dummy variable that takes a value of one if the loan record indicates full documentation, and zero otherwise.

Finally, for the other borrower characteristics, income likely is related to borrower credit ratings. Controlling for risk rating, higher income borrowers may face higher cost of default, which, from Campbell and Cocco (2003), would suggest higher income borrowers would prefer FRM financing. With regard to income uncertainty, Campbell and Cocco (2003) show that borrowers with risky income should prefer FRM financing compared to traditional ARM financing. However, option ARMs, which provide flexibility in payments, may be preferred by borrowers with highly variable incomes.

\section{Data}

The loan level data used in the empirical analysis are from Lender Processing Services (LPS) Applied Analytics, Inc. The data represented in the dataset account for about 60percent percent of the mortgage market (most of the large mortgage servicers are represented). Our sample includes over 9 million first-lien loans for home purchases originated in the U.S. between January 1, 2000 and December 31, 2007. Table 1 shows descriptive statistics for the variables used in the analysis. The share of ARMs jumped dramatically from about 12 percent mid-2003 to 47percent in early 2005 (also see Figure 3). The share of ARM loans remained relatively high until the end of 2005 and then began its decline. In December of 2007, it stood at 7 percent. The popularity of option ARMs also has changed over time. Early in our sample, only 1 or 2 percent of all loans were option ARMs, but in 2007 this share was as high as 11percent (Table 1).

The measure of borrower credit risk $(C R R)$ is the borrower's FICO score at the time the loan is closed (originated). About half of our sample had FICO scores of 661 to 759 at the time of loan origination (medium FICO), 27 percent had FICO scores of 760 or above (high FICO), and FICO scores of the remaining 23 percent were below 660 (low FICO). The data also include a lender-designated subprime categorization of loans. The categorization can reflect the credit risk of the borrowers as well as features of a loan that contribute to credit risk. Notably, the share of subprime loans in the sample increased over time jumping from 1-3 percent of the sample in 2000-2003 to above 10 percent in 2004-2006, and finally dropping to 5 percent in 
2007. The table also shows the share of loans meeting the size limits that conform to GSE standards as well as a lender provided indicator of full documentation of a mortgage loan. ${ }^{12}$

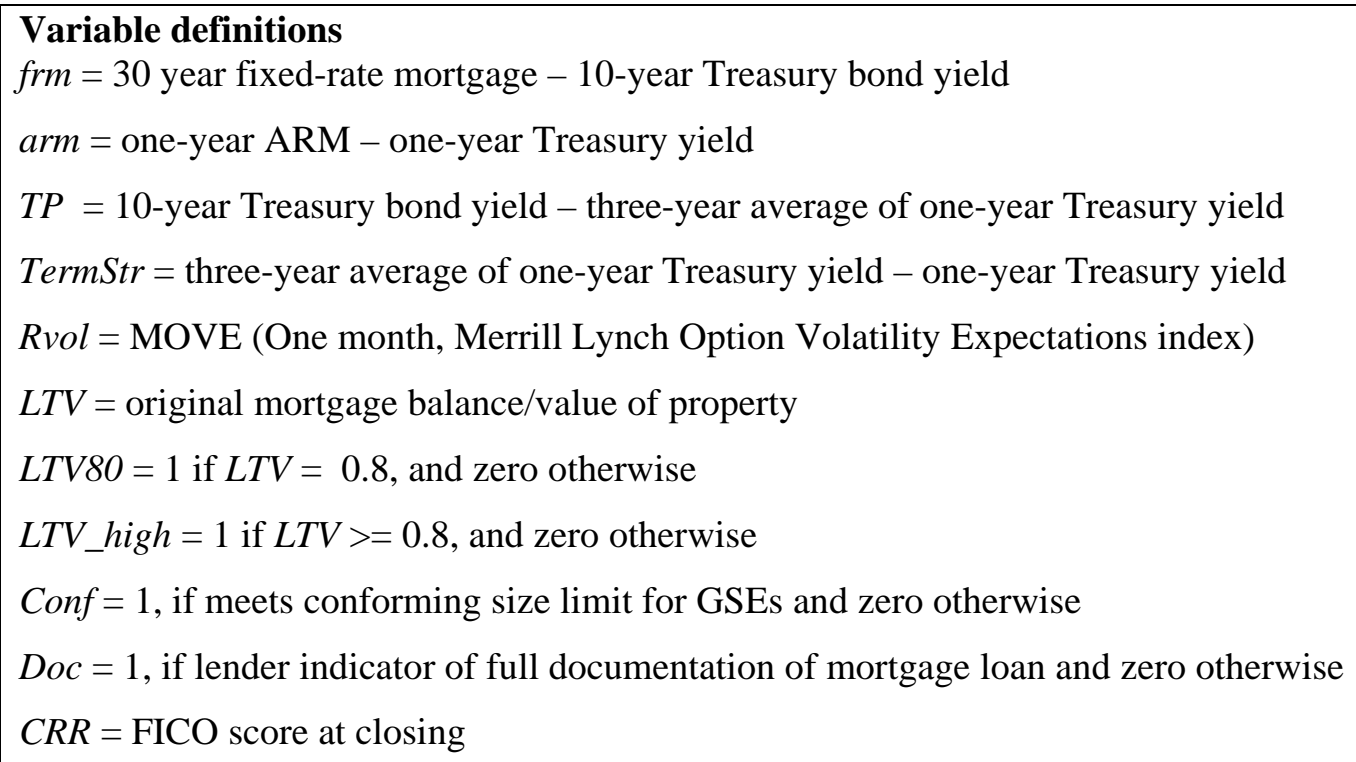

The loan-to-value ratio is the original loan amount divided by the value of the property. In the LPS Analytic data, the ratio is for the individual loan. To qualify for conforming loan without mortgage insurance generally requires a loan-to-value ratio of at least 80 percent on a first lien. A borrower wishing to finance a property with less than a 20 percent down payment

\footnotetext{
${ }^{12}$ Note that there are a number of missing observations in this field.
} 
might obtain an 80 percent loan-to-value first-lien mortgage and also obtain a second mortgage when purchasing a home. To control for the potential that first liens just meeting the 80 percent limit may also involve second mortgages at the time of financing we include a control for loanto-value ratios on first liens that are exactly 80 percent.

For the market interest rates, the long-term risk-free rate $(L R)$ is the yield on the 10-year constant maturity Treasury bond. The short-term risk-free interest rate $(S R)$ is the yield on the one-year constant maturity Treasury note. The term premium is the 10 year term premium along the lines of a "rule-of-thumb" estimate used in Koijen et al. (2008), where the term premium is the difference between the ten-year Treasury bond yield and the three-year average interest rate of the one-year Treasury bill. The fixed-rate mortgage interest rate used in the analysis is from Freddie Mac for 30-year conventional loans. The adjustable-rate is for the one-year adjustable rate loan benchmarked to the one-year Treasury yield. The term structure for short-term interest rates is estimated as the difference between the three-year average of the one-year Treasury rate and the one-year Treasury rate in the month a mortgage is closed. Given the mortgage interest rates and market interest rate terms, the ARM margin (arm) and FRM margin (frm) are derived as described earlier. Interest rate volatility is measured by the Merrill Lynch Option Volatility Estimate (MOVE) index. The interest volatility is for the month in which a mortgage is originated.

The house price indexes are from LP CoreLogic. The indexes are measured at the county level. House price appreciation is measured over the two years prior to the month of closing of a loan. House price volatility is measured as the standard deviation of the monthly house price index over the two years prior to closing. To control for income, we use metro area per capita values adjusted for inflation in the year in which the mortgage loans originated. The measure of income uncertainty is the unemployment rate in a county for the month in which a mortgage loan is originated.

\section{Empirical Results}

In the empirical analysis of loan choice we use a multivariate probit framework. Mortgage loan choices are grouped into three categories-fixed interest rate, non-option adjustable interest rate, and option adjustable rate. The right-hand side variables are listed in the box. 
The three main hypotheses we assess in the analysis are as follows:

1. House price appreciation weakens the link between mortgage financing choice and fundamentals as measured by mortgage pricing terms and other interest-rate-related metrics - where the null hypothesis is that there is no effect of house price appreciation.

2. The mortgage pricing terms and other interest related metrics are less relevant to borrowers with lower credit risk rating — where the null hypothesis is the there is no difference.

3. The effects of house price appreciation on mortgage financing choices are more pronounced for borrowers with lower credit risk ratings—where the null hypothesis is that there is no difference.

We first present results for a sample of loans for properties in 46 states and the District of Columbia. ${ }^{13}$ The sample covers the period from 2000 through 2007 and we look only at loans for home purchases (rather than refinancing). ${ }^{14}$ The second stage of the empirical analysis compares the results for three credit risk (FICO) groups defined in the box. We test robustness of the results by considering two subsamples. One subsample includes the states that experienced exceptionally rapid house price appreciation during the housing boom. These states include the four so-called sand states of Arizona, California, Florida, and Nevada, as well as Hawaii, Maryland, and Virginia. The other subsample consists of the other 39 states and the District of Columbia.

\subsection{Overall sample}

Table 2 presents results for first-lien mortgages for home purchases for the full sample. All the estimations control for year-fixed effects, ${ }^{15}$ state-fixed effects, and levels of significance are based on robust standard errors clustered on counties. ${ }^{16}$ The results related to non-option

\footnotetext{
${ }^{13}$ The excluded states are Indiana, Kentucky, Mississippi, and Nebraska. The population of the option ARM cells for these states for various months was insufficient to allow for estimations for FICO groups that included year-fixed effects and state-fixed effects.

${ }^{14}$ We view a refinancing decision as different from one to purchase a home. Additional factors, such as the interest rate on the previous loan and the type of previous loan, might be important in mortgage refinance decisions.

${ }^{15}$ The year-fixed effects reflect the propensity to choose ARM financing relative to 2007.

${ }^{16}$ The sample was also filtered to include only loans with original loan-to-value ratios greater than 10 percent.
} 
ARMs versus FRMs for first lien mortgages are presented in the first column of statistics and the results for the option ARMs choice are presented in the second.

In the probit estimation, the loan pricing terms and other interest-rate-related metrics enter on their own and interacted with the house price appreciation in the market (county) over the two years prior to the closing of a mortgage loan. The coefficients without the interaction relate to the effects on probability of choosing an ARM over a FRM when house price appreciation is zero. For those coefficients, the loan pricing variables (FRM and ARM margins) have the expected signs and are highly statistically significant for both non-option and option ARM versus FRM choices. Higher average margins on ARMs lower the probability that borrowers will opt for an ARM, and higher margins on FRMs increase the likelihood of a borrower selecting an adjustable-rate loan to purchase a house.

Likewise, the other variables relating to market interest rates have the expected signs when house price appreciation is zero and are statistically significant. A higher term premium increases the likelihood a borrower will select ARM financing. The results related to expected short-term rates relative to current short-term interest rates and to interest rate volatility are consistent with predictions from Elliehausen and Hwang (2010) in that the two metrics tend to have offsetting effect as $L T V$ increases. Higher expected short-term rates relative to current levels make ARM financing more attractive, with the effect increasing with the loan-to-value ratio of a loan. In the case of interest rate volatility, at high LTVs, higher volatility favors FRM financing.

With regard to the interaction with house price appreciation, the results consistently reject the hypothesis that house price appreciation does not affect the sensitivity of mortgage financing choice to mortgage pricing terms or the other interest-related metrics. In the case of the margins on mortgage interest rates, the interacted terms for the ARM and FRM margins are highly statistically significant and the signs indicate that the sensitivity of borrowers to the two margins declines with increase in house price appreciation. Similar results hold for the interaction with the term premium and expected short-term interest rate, though for the option ARM the coefficient for the interaction with the term premium and house price appreciation is only marginally significant. The exception to the general pattern is the set of results for the interaction of house price appreciation with the measure of interest rate volatility, where the responsiveness increases slightly with the pace of appreciation. 
The magnitude of the effects of the interaction of house price appreciation with the mortgage pricing and the other interest-rate-related metrics can be illustrated through the marginal effects on the probability of choosing ARM versus FRM financing. Marginal effects shown in Figures 5a and 5b are evaluated at sample means. The size of the change in each of the variables considered is equal to one standard deviation (for the entire sample period). Figure 5a shows three elements of the marginal effects for the mortgage pricing margins and the term premium, and Figure 5b shows the results for short-term interest rate term structure and interest rate volatility. The green bars show the marginal effects of the variables when house price appreciation is equal to zero, and the other variables measured at their means. The red bars show the marginal effects (offset) due to the interactions with house price appreciation measured at its mean. The blue bars show the overall effect of changes in the mortgage pricing terms the other interest rate-related metrics when house price appreciation is measured at its mean.

In Figure 5a, all the marginal effects are economically and statistically significant. In the case of the ARM margin ( $\mathrm{arm}$ ), for example, with zero house appreciation, a 0.8 percentage point increase in the margin (one standard deviation) would reduce the probability of choosing ARM financing by 11 percentage points. To put that figure in perspective, in the sample the ARM share of mortgage originations in 2005 was 43 percent. ${ }^{17}$ Measured at its mean for the sample period, the interaction with house price appreciation reduces the marginal effect of a change arm by about one-third. The offset for FRM margin (frm) is also about one-third, relative to when house price appreciation equals zero. For the term premium, the offset is relatively small, though statistically significant. ${ }^{18}$

In Figure 5b, again measured at the variables’ means, for a 1.1 percentage point increase in the short-term interest rate structure, the house price appreciation reduces the impact on the probability of selecting ARM financing by 4 percentage points (about 1/3 of the variable's impact when there is no house price appreciation). As suggested by the results in Table 2, the interaction with house price appreciation increase somewhat the expected negative effect of interest rate volatility on the probability of a borrower choosing ARM financing. Although the effect is statistically significant, the effects of interest rate volatility tend to be small. In the

\footnotetext{
${ }^{17}$ Here, the probability of an individual borrower selecting ARM financing ranges from zero to 100percent.

${ }^{18}$ The results for expected short-term interest rates and interest rate volatility are similar in terms of the interaction of house prices reducing the sensitivity of financing choice to the variables.
} 
figure, a one standard deviation change in the MOVE index has a small effect on mortgage choice. $^{19}$

The magnitudes of the offsets from the interaction between house price appreciation and the loan pricing terms and other interest-rate-related metrics increase with the pace of house price appreciation. This is illustrated in Figure 6 for the loan pricing margins and the term premium. Valuing all the variables at the means for the loans in the sample that fall in the bottom quartile of house price appreciation, there is little or no offset to the marginal effects related to house price appreciation. In contrast, for loans in the top quartile of house price appreciation the offsets are large in size and highly statistically significant. In the top quartile, the largest proportional effect is for the ARM margin. With the offset, the overall marginal effect of a change arm on the probability of a borrower's selecting ARM financing is less than a third of the effect for borrowers with loans in markets with house price in the bottom quartile. In all cases, however, overall marginal effects are statistically significant. That is, even with the effects of house price appreciation, the mortgage rate margins and the term premium have economically and statistically significant effects on mortgage financing choice, even for borrowers with observation in the top quartile of house price appreciation.

Estimating the model with all covariates but fixed effects interacted with house price appreciation (available upon request) did not lead to a different conclusion. Given our focus on the fundamentals and to facilitate interpretation, we chose to present the results with interactions for the fundamentals only.

In addition to the effects through the interaction with the loan pricing and other interest rate metrics, the coefficients on house price appreciation in Table 2 are positive and highly significant. That is, higher house price appreciation, by itself, increases the probability of a borrower choosing ARM financing. Figure 7 shows actual, predicted, and counterfactual shares of ARM financing with observations measured at overall sample means and the means for the lower and upper quartiles by house price appreciation. The actual (red bars) and predicted (blue bars) shares of ARM loans in the sample show the probability of ARM choice increase with house price appreciation. For the counterfactuals (green bars), for each loan, the two-year house price appreciation prior to closure was set 13 percentage points (one standard deviation) higher

\footnotetext{
${ }^{19}$ For the sample the MOVE averaged about 100, with a standard deviation of about 20.
} 
than the actual observed value. ${ }^{20}$ The results of the counterfactual demonstrate that higher expected house price appreciation would lead to a higher likelihood of selecting an ARM. For instance, for the borrowers who experienced relatively low house price appreciation during the sample period (i.e., their house price appreciation fell in the bottom quartile), expectations of extra appreciation would lead to an increase in the ARM share from about 20 percent to 26 percent. For borrowers who experienced a more rapid house price appreciation (top quartile), the jump in probability of choosing an ARM would have been larger (from 45 percent to 56 percent). The difference between the predicted and the counterfactual estimates indicates that the marginal effects in absolute terms rise somewhat, moving from the lower to the upper quartile.

Regarding the other control variables, lower loan LTVs tend to be associated with borrowers’ selecting ARM financing vs. FRM financing-both non-option and option ARMs. The results regarding borrowers with exactly 80 percent down on the first lien (i.e., borrowers who are more likely to have a second mortgage) indicate that such borrowers are more likely to opt for ARM financing.

Borrowers with mortgage amounts meeting the conforming loan limits for the GSEs are more likely to use FRM financing. This is consistent with earlier cited research that finds that rates on fixed-rate mortgages are lower on loans meeting the conforming standards compared with otherwise similar larger fixed-rate loans. To the extent the results for the conforming size variable reflect interest rate differentials, the findings are also consistent with our other results showing mortgage choice is sensitive to mortgage pricing terms frm and $\mathrm{arm}^{21}$

The degree of disclosure and credit rating of borrowers also are related to mortgage financing choice. Borrowers with loans identified in the sample as having full documentation are more likely to use FRM financing than a non-option ARM. The coefficient on the FICO score and the lender identification of a loan being subprime indicate that higher risk loans tend to be associated with ARM financing - both non-option and option ARMs. Finally, higher income in a metropolitan area is associated with a higher probability of a borrower using ARM financing

20 In the probit analysis, house price appreciation is measured as the two-year log change. Converted to percent changes, one standard deviation is 13 percentage points.

${ }^{21}$ As a robustness check, we also estimated the model for conforming and nonconforming (jumbo) rates separately (estimation results available upon request). Although there are differences in the size of coefficients for the two types of loans (the offsets are larger for jumbo loans), our conclusions remain. It is also useful to keep in mind that over 90 percent of loans in our sample are conforming loans (see Table 2). 
and a higher county unemployment rate is associated with a higher probability of borrowers using ARM financing, though the result is only statistically significant in the case of FRM versus option ARMs choice. Relative to 2007, borrowers were less likely to select a non-option ARM in 2000 and 2001, but were somewhat more likely to choose a non-option ARM in the housing boom years 2004 and 2005. For option ARMs, the year effect dummies indicate higher shares for 2004 and 2005, as well as 2002 relative to 2007.

\subsection{Results by Credit Risk Group}

Based on the results in Table 2 as well as in Figures 5 and 6 we can reject the hypothesis that house price appreciation does not affect mortgage financing choice. In particular, the evidence is consistent with higher house price appreciation reducing the sensitivity of borrowers to fundamentals, which previous research finds have been instrumental in mortgage financing choices, during the housing boom. Because the housing boom was associated with a notable increase in the share of higher credit risk borrowers, it is possible that the findings reflect the mix of borrowers. Related to the hypotheses noted earlier, the mix of borrowers could matter if mortgage pricing terms and other interest-related metrics are less relevant to borrowers with lower credit risk ratings or the effects of house price appreciation on mortgage financing choices are more pronounced for borrowers with lower credit risk ratings.

For empirical analysis of the credit risk groups, we separate the sample into high (FICO score at origination of 760 or above), medium (FICO score at origination between 651 and 759), and low (FICO score at origination of 660 or below) groups. ${ }^{22}$ Table 3a presents results for nonoption ARM vs. FRM loans, and the results for option ARM vs. FRM loans are in Table 3b. The first three rows of the two tables show estimation results for each of the three credit groups, and the last two columns show the differences between the high FICO group and the other two groups.

\footnotetext{
${ }^{22}$ Another commonly used cutoff in the literature is a FICO score of 620, as mortgages with borrower FICO scores just below 620 have lower probability of being securitized than scores just above that cutoff (Krainer and Laderman 2013). Thus, borrowers on either side of the cutoff might have been subjected to different screening procedures and faced different loan pricing options. We estimated the model separately for those with FICO scores below 620 and those with scores between 620 and 659 (results available upon request), and the estimation results do not alter our conclusions.
} 
Tables $3 \mathrm{a}$ and $3 \mathrm{~b}$ present the results by credit risk group. The results from the probit estimation indicate that the relation of fundamentals to mortgage financing choice for each of the credit risk groups is statistically significant and their signs are consistent with those for the overall sample. For non-option ARMs in Table 3a, when house prices are flat (house price appreciation is zero), lower FICO groups are found to be more sensitive to the key loan pricing and interest rate terms. On balance, the difference between the coefficients for high FICO and the other two groups are statistically significant (the exceptions are (1) the sensitivity to interest rate volatility, which, for the most part, is not found to be statistically different between the three subgroups, and (2) the ARM margin, where only the difference between low and high FICO groups is statistically significant). For the option ARMs in Table 3b, in the fewer instances in which the coefficients on the loan pricing terms and interest rate metrics (not interacted with house price appreciation) differ significantly between the high FICO and lower FICO groups, the results are consistent with greater sensitivity among the lower FICO groups.

The offsetting effects of house price appreciation on the sensitivity to fundamentals related to loan pricing terms and interest rate metrics are evident across risk ratings. The offsets, however, tend to be larger in magnitude for the lower FICO groups. For non-option ARMs, the coefficients related to the offsets to the ARM margin, term premium, and short-term interest rate term structure are statistically significant and larger in magnitude for the low FICO group compared with the high FICO group. For the medium FICO group, the difference is also significant in the case of the term premium. ${ }^{23}$ For option ARMs, the magnitude of coefficients related to the offsets are significantly larger for the low FICO group compared with the high FICO group in the case of the loan pricing margins. ${ }^{24}$ In no instance is the difference significant and larger in magnitude for the high FICO group.

With respect to house price appreciation itself, only the medium FICO group's response to house price appreciation is found to be significantly higher than that for the high FICO group for the choice between FRM and non-option ARM financing. For house price volatility, the coefficients had the expected sign and were significant for the low FICO group in Table 3a and for the medium and low FICO groups in Table 3b.

\footnotetext{
${ }^{23}$ As for the overall sample, the interaction of house price appreciation and interest rate volatility tends to reinforce, rather than offset, the expected effect of interest rate uncertainty on mortgage financing choice.

${ }^{24}$ The difference in the offset also is significant for the short-term interest rate structure for loans with low LTV ratios.
} 
These results indicate that, on balance, lower FICO groups tend to be more sensitive to loan pricing and other interest-rate-related metrics when house prices are flat, but some of the offsets from the interaction with house price appreciation tend to be more pronounced for low FICO borrowers. On balance, the lower FICO groups tend to be more, or at least as, responsive to fundamentals as borrowers in the high FICO group. This is illustrated in Figures 8a-8c, which shows the overall marginal effects of ARM margin (Figure 8a), FRM margin (Figure 8b), and term premium (Figure 8c) on the probability of choosing an ARM mortgage evaluated at sample means, as well as at the means for the top and bottom quartile of house price appreciation. ${ }^{25}$ The marginal effects for each of the risk groups are statistically significant. The figure also indicates that the marginal effects tend to be larger in magnitude for the low FICO groups compared with the high FICO group. The one exception is the small difference for ARM margins in the top quartile of house price appreciation.

The results, then, are consistent with lower FICO borrowers, on balance, being at least as, if not more, sensitive to key loan pricing and other interest rate metrics compared with high FICO borrowers. At the same time, the unconditional propensity to select ARM financing was higher among low FICO borrowers during the peak of the housing boom, as indicated in Figure 9, which shows monthly average shares of ARMs for high and low FICO groups, as well as the fitted values from our model. As Figure 9 demonstrates, our estimated model captures the dynamics of ARM shares well.

During the housing boom, the higher ARM shares for the low FICO group appear to have been due largely to combined differences in sensitivity to and the values of the borrower credit risk metrics (borrower FICO score and subprime designation). This is illustrated in Figures 10a and 10b. The figures show estimated critical values related the probability of choosing nonoption (Figure 10a) and option (Figure 10b) ARMs in 2005 for high (red bars) and low FICO borrowers (blue bars). The critical values are derived using the estimated coefficients from Table 3 applied to the respective mean values in 2005 for the high FICO and low FICO groups. Given a standard normal distribution, the critical values imply estimated non-option shares of 20 and 40 percent for the high FICO and low FICO groups, respectively. The corresponding sample

\footnotetext{
${ }^{25}$ Note, in Figures 8a-8c we do not show the decomposition of the overall effect into the effect under zero house price appreciation and the offset.
} 
shares are 20 percent and 38 percent. The estimates are the same as the actual shares for option ARMs, 4 percent for the high and 11 percent for the low FICO groups.

In the figures, the green bars show the contributions from the groupings of right-hand side variables to the difference between the two critical values - that is, the green bars sum to 0.59 [(-.23)-(.82)] in Figure 10a and to 0.57 [(-1.23)-(-1.80)] in Figure 10b. The market metrics include the mortgage pricing terms, other interest-rate-related terms, as well as those variables interacted with house price appreciation. The nonprice terms include the LTV metrics, whether loans are conforming, and the degree of documentation. The credit risk metrics include FICO score and the subprime designation. The housing metrics include house price appreciation and the standard deviation of house prices. The income metrics include the median county income and the unemployment rate. The fixed effects include the time effects, the state effects, and the constant term.

In the figures, among the groupings of the variables, the combined effects of market metrics tend to push up the share of ARMs for the low FICO group relative to the high FICO group. For option ARMs the income groups also tend to push up the low FICO share. Also for both ARM choices, the credit risk metrics grouping pushes up ARM share for the low FICO borrowers relative to the high FICO cohort. . For the other groupings, notably fixed effects, the net impact lowers the predicted ARM for the low FICO group (raises it for the high FICO group).

Figures 10a and 10b indicate that credit risk metrics worked to raise the ARM shares of low FICO borrowers compared with high FICO borrowers during the peak of the housing boom. Obviously, the low FICO group has lower average FICO scores and also a higher share of subprime borrowers (Table 7). Figure 11 plots estimated ARM shares for high and low FICO groups along with the ARM share for the low FICO group that would arise under a counterfactual scenario, where all borrowers in the low FICO group are given the average monthly FICO scores and subprime shares of the high FICO group. The results imply that the impact of the credit risk variables is quite powerful, and that the low FICO borrowers would have had ARM shares even below those of the high FICO group if they were given higher FICO scores and fewer of them had loans with subprime designation.

This exercise does not answer the question of why credit risk metrics can explain a large part of the differential in ARM shares between low and high FICO groups. As previously 
discussed, it could be that these metrics proxy for the degree of financial sophistication of borrowers, as opposed to the results reflecting economic decisions related to the effects of risk aversion, credit constraints (affordability), or differences in expectations regarding refinancing horizons among the two groups of borrowers. It is worth noting, however, that our findings that low FICO borrowers are at least as sensitive to the fundamentals related to mortgage pricing and other interest-rate-related metrics as the high FICO group seem more consistent with economic considerations affecting decisions compared with an explanation that relies on a systematic lack of financial sophistication among borrowers in the low FICO group.

\subsection{Robustness Checks: Isolating the States with Rapid House Price Appreciation}

Seven states in our sample (AZ, CA, FL, NV, HI, MD and VA) experienced exceptionally rapid house price appreciation during the housing boom in comparison to the other states in the sample. ${ }^{26}$ To check whether our conclusions are driven by these seven states, we consider two subsamples: one with these seven states and one excluding these seven states (i.e., the other 39 states and the District of Columbia). Estimation results for the two subsamples are presented in Tables 4a and 4b. Mortgage pricing and other interest terms have the expected sign for both sub-samples and are significantly different from zero. Moreover, for the coefficients on loan margins and the other interest-rate-related metrics when house price appreciation is zero, the differences between the coefficients for the non-option ARM vs. FRM choice for the two subsamples tend to be small and generally not statistically significant (Table 4a). For option ARM vs. FRM choice, only the difference in the sensitivity to FRM margin is significant (with high appreciation states showing more sensitivity). For the non-option and the option ARM vs. FRM choice the differences in results for the two subsamples mainly involve the various control variables.

The results for the interactions of loan margins and interest rate metrics for the states in the two subsamples in Tables $4 \mathrm{a}$ and $4 \mathrm{~b}$ are similar, with a few exceptions. The exceptions among the offsets (coefficients on the key explanatory variables interacted with house price appreciation), however, are not systematic. In the case of non-option ARMs, the offset on the

\footnotetext{
${ }^{26}$ The average appreciation during 2003-2005 (housing boom) period was 26percent in AZ, 35percent in CA, 31percent in FL, 36percent in HI, 38percent in NV, 31percent in MD, and 29percent in VA. For comparison, the average appreciation during the same period was 13percent for all other states in the sample.
} 
ARM margin is larger in magnitude for the high appreciation states, but this is the only statistically significant difference in the offsets. For option ARMs, there is only one marginally significant difference in the offsets.

These results regarding the loan margins and other interest rate metrics indicate that the full sample results are not driven by the seven high appreciation states. This is illustrated further in Figure 12, which shows marginal effects for the ARM margin, FRM margin, and term premium for the full sample and the sample that excludes the seven high appreciation states. As before, the marginal effects are shown for three different sets of values for explanatory variables - at the sample means and at the means for the top and bottom quartile of house price appreciation. The total effects for the full sample and the subsample are similar. One difference is the effect of changes in the ARM margin is larger in magnitude for the sample excluding the seven high appreciation states when derived using the average values of the explanatory variables from the observation corresponding to the top quartile of house price appreciation. This reflects the relatively large offsetting effect from the interaction of house price appreciation for non-option ARMs on the ARM margin for the seven high appreciation states. In fact, for those states, separate estimates show that the total marginal effect of the ARM margin is positive and significant when derived for the top quartile of house price appreciation for the sub-sample of high house price appreciation states.

With regard to the coefficients on house price appreciation and house price volatility, the results for the sample excluding the seven high appreciation states have the expected signs and are highly significant, for both non-option and option ARMs. In fact, for the non-option ARM results, the coefficient on house price appreciation is larger in magnitude for the larger subsample (perhaps reflecting more variation in house prices in this subsample compared with the subsample of high appreciation states). In the case of house price volatility, only the sample covering the larger set of states has the expected sign.

The results for the two subsamples for the three credit risk groups also indicate that the full sample effects are not driven by the states that experience especially rapid house price appreciation in the housing boom. For the sample that excludes the seven high appreciation states, estimation results by FICO group are presented in Tables 5a (for non-option ARM vs. FRM mortgage choice) and 5b (for option ARM vs. FRM mortgage choice). The results for the seven high appreciation states are presented in Tables $6 \mathrm{a}$ and $6 \mathrm{~b}$. The results by FICO group for 
the larger sample (Tables 5a and 5b) are very similar to those for the overall sample for the loan margins and other interest rate variables. The coefficients representing the effects for house price appreciation at zero mirror those for the overall sample-that is, with the results showing higher sensitivity for the lower FICO groups. The interaction effects also are similar. The coefficients on house price appreciation in Table 5a are larger than the corresponding metrics for the overall sample, which is consistent with the findings in Table 3.

\section{Conclusion}

During the housing boom in the 2000s, gains in house prices were especially high and far outstripped gains in rental rates. The analysis in this paper presents evidence that in the boom years house price appreciation did impact the influence of fundamentals in mortgage borrowers’ decision making. In particular, we find that house price appreciation weakens the link between mortgage financing choice and fundamentals as measured by mortgage pricing terms and other interest-rate-related metrics.

The housing boom also was marked by greater access to mortgage credit for lower credit rated borrowers. For these borrowers, we find countervailing evidence regarding the role of fundamentals and the effects of house appreciation. In the absence of house price appreciation, the mortgage pricing terms and other interest-related metrics are more relevant to borrowers with lower credit risk ratings. On the other hand, the dampening effects of house price appreciation on the influence of fundamentals are more pronounced for borrowers with lower credit risk ratings. On balance, low credit rated borrowers tend to be at least as responsive to interest rate fundamentals as high risk rated borrowers.

Lower credit rated borrowers in the sample did have higher propensity to choose ARM financing, even taking into account the effects of mortgage pricing terms, other interest-raterelated terms as well as other control variables. Also, among lower credit rated borrowers that propensity appears to be positively related to borrowers' FICO scores. In light of the evidence related to loan pricing terms, other interest rate metrics, and fixed effects, the relation of the credit risk metrics to mortgage financing choice seems more consistent with economic considerations affecting decisions compared with an explanation that relies on a systematic lack of financial sophistication among borrowers in the low FICO group. 
Finally, the findings related to the effects of house price appreciation and credit risk ratings on mortgage financing choices during the housing boom do not appear to be driven by the states that experienced unusually high house price appreciation during the housing boom. 


\section{References}

Alm, James R., and James R. Follain. 1987. “Consumer Demand for Adjustable-Rate Mortgages.” Housing Finance Review, 6 (Spring 1987), 1-6.

Baesel, Jerome B., and Nahum Biger. 1980. "The Allocation of Risk: Some Implications of Fixed vs. Index-Linked Mortgages.” Journal of Financial and Quantitative Analysis 15 (June 1980), pp. 457-68.

Barlevy, Gadi and Jonas D.M. Fisher. 2011. "Mortgage Choices and Housing Speculation.” Federal Reserve Bank of Chicago Working Papers 2010-12.

Brueckner, Jan K. 1986. “The Pricing of Interest Rate Caps and Consumer Choice in the Market for Adjustable Rate Mortgages,” Housing Finance Review 16 (Fall 1986), pp 119-136.

Brueckner, Jan K. and James R. Follian. 1988. "The Rise and Fall of the Arm: An Econometric Analysis of Mortgage Choice.” The Review of Economics and Statistics, Vol. 70, No. 1

(February 1988), pp. 93-102.

Bucks, Brian, and Karen Pence. 2008. "Do Borrowers Know their Mortgage Terms?" Journal of Urban Economics, vol. 64, no. 2, pp. 218-233.

Chomsisengphet, Souphala and Anthony Pennington-Cross. 2006. Federal Reserve Bank of St. Louis Review, January/February 2006, 88(1), pp. 31-56.

Campbell, John Y., and Joao F. Cocco. 2003. "Household Risk Management and Optimal Mortgage Choice.” Quarterly Journal of Economics 118(4), pp. 1,449-1,494.

Coulibaly, Brahima, and Geng Li (2009). "Choice of Mortgage Contracts: Evidence from the Survey of Consumer Finances," Real Estate Economics, vol. 37, no. 4, pp. 659-673.

Demyanyk, Yilia. 2009. “Ten Myths About Subprime Mortgages.” Federal Reserve Bank of Cleveland Economic Commentary July 2009.

Dhillon, Upinder S., James D. Shilling, and C.F. Sirmans. 1987. "Choosing Between Fixed and Adjustable Rate Mortgages: Note.” Journal of Money, Credit and Banking, vol. 19, No. 2, (May, 1987), pp. 260-267.

Doms, Mark and John Krainer. 2007. "Innovations in mortgage markets and increased spending on housing.” FRBSF Working Paper Series, 2007-05.

Elliehausen, Gregory and Min Hwang. 2010. Mortgage Contract Choice in Subprime Mortgage Markets. Federal Reserve Board Finance and Economics Discussion Series 2010-53. 
Foote, Christopher L., Kristopher S. Gerardi, and Paul S. Willen. 2012. "Why Did So Many People Make So Many Ex Post Bad Decisions? The Causes of the Foreclosure Crisis.” Federal Reserve Bank of Boston Working Paper No, 12-2.

Gerardi, Kristopher, Andreas Lehnert, Shane M. Sherlund, and Paul S. Willen. 2008. "Making Sense of the Subprime Crisis.” Brookings Papers on Economic Activity 2: 69-145.

Jones, Steven T. and Norman G. Miller. 1995. "Residential Mortgagee Choice: Does the Supply Side Matter.” Journal of Housing Economics 4, 71-90 (1995).

Krainer, John. 2010. "Mortgage Choice and the Pricing of Fixed-Rate and Adjustable-Rate Mortgages.” FRBSF Economic Letter 2010-03 (February 1).

Krainer, John and Mark Doms. 2007. "Innovations in Mortgage Markets and Increased Spending on Housing.” Federal Reserve Bank of San Francisco. July.

Krainer, John and Elizabeth Laderman. 2013. "Mortgage Loan Securitization and Relative Loan Performance.” Journal of Financial Services Research, February 2013.

Koijen, Ralph, Otto Van Hemert, and Stijn Van Nieuwerburgh. 2009. “Mortgage Timing.” Journal of Financial Economics 93(2, August), pp. 292-324

Moench, Emanuel, James Vickery, and Diego Aragon. 2010. "Why is the Market Share of Adjustable-Rate Mortgages So Low?” Federal Reserve Bank of NY Current Issues, Vol. 16, No. 8, December 2010.

Nothaft, E. Frank and H.K. George Wang. 1992. "Determinants of the ARM Share of National and Regional Lending," Journal of Real Estate Finance and Economics, 5: 219-234.

Passmore, Wayne, Shane M. Sherlund, and Gillian Burgess. 2007. “The Effect of Housing Government-Sponsored Enterprises on Mortgage Rates.”

Smith, Margaret Hwang and Gary Smith. 2006. "Bubble, Bubble, Where's the Housing Bubble.” Brookings Papers on Economic Activity, 2006: 1-50.

Statman, Mehir. 1982. "Fixed or Index-Linked Mortgages from the Borrower's Point of View: A Note.” Journal of Financial and Quantitative Analysis 17 (September 1982), 451-57.

Vickery, James. 2007. “Interest Rates and Consumer Choice in the Residential Mortgage Market.” Federal Reserve Bank of New York Working Paper.

Wheaton, W. C. and G. Nechayev. 2008. "The 1998-2005 Housing 'Bubble' and the Current 'Correction': What's Different this Time?” Journal of Real Estate Research 30(1). 
Figure1. House Price Index and Price/Rent Ratio

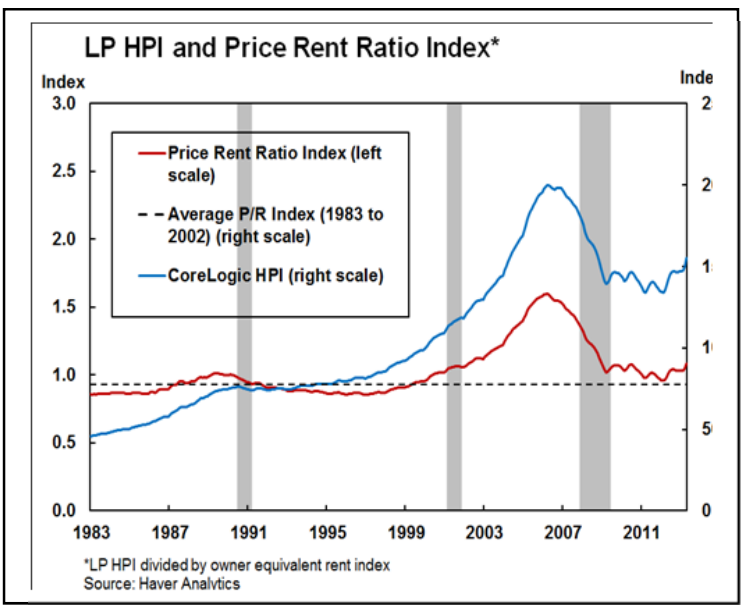

Figure3. ARM Shares: Historical Series

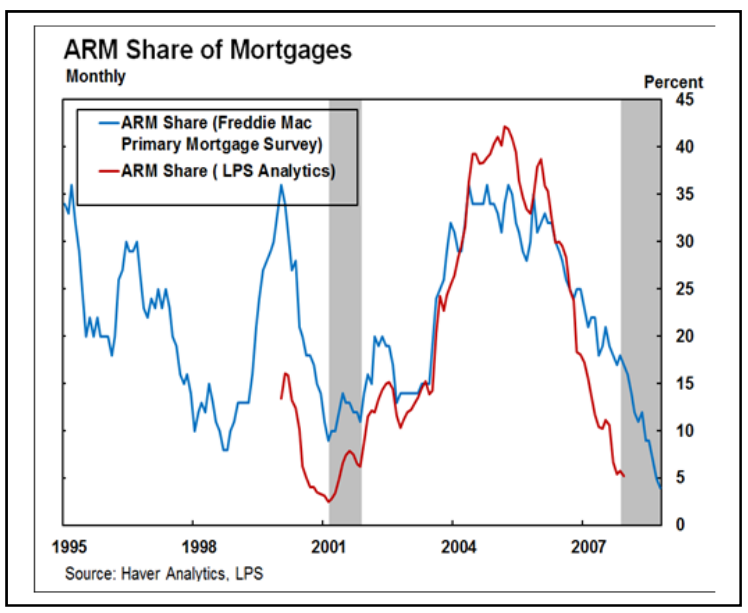

Figure 5a. Marginal Effects At Sample Means

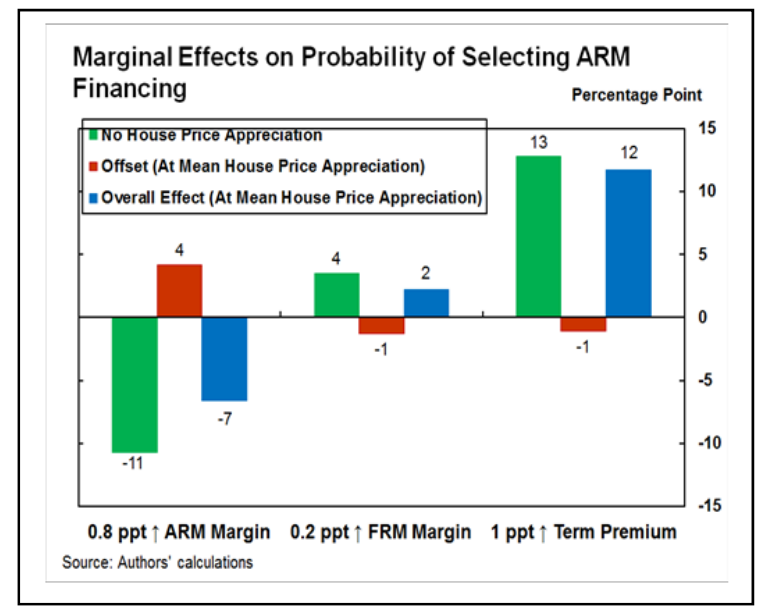

Figure 2. Home Sales and Homeownership

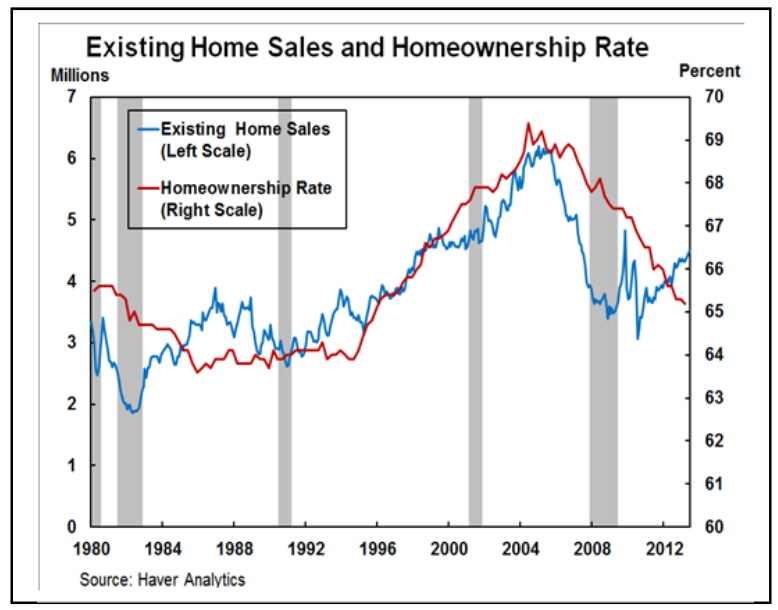

Figure 4. Sample ARM Shares by FICO Group

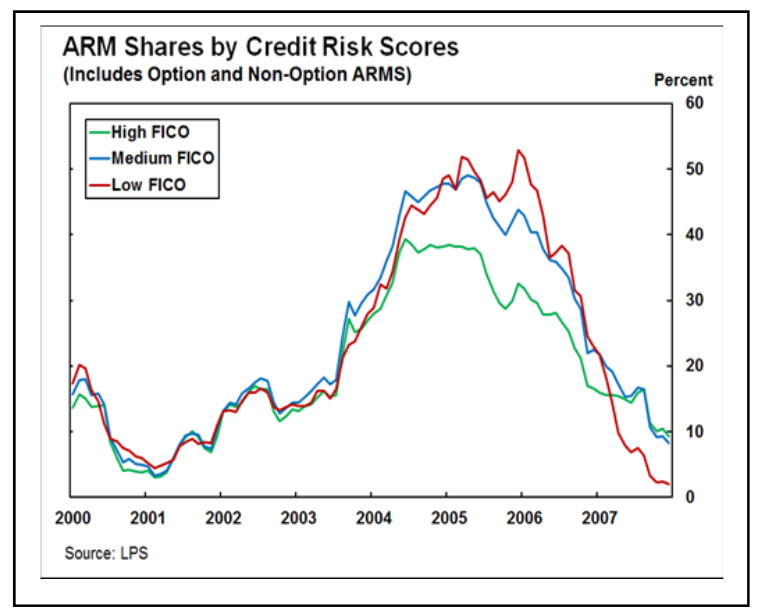

Figure 5b. Marginal Effects At Sample Means

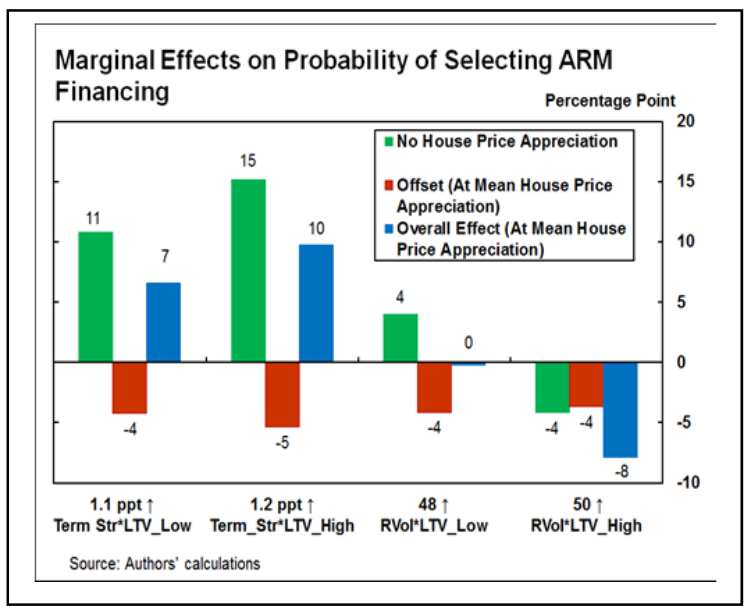


Figure 6. Marginal Effects at Select Values

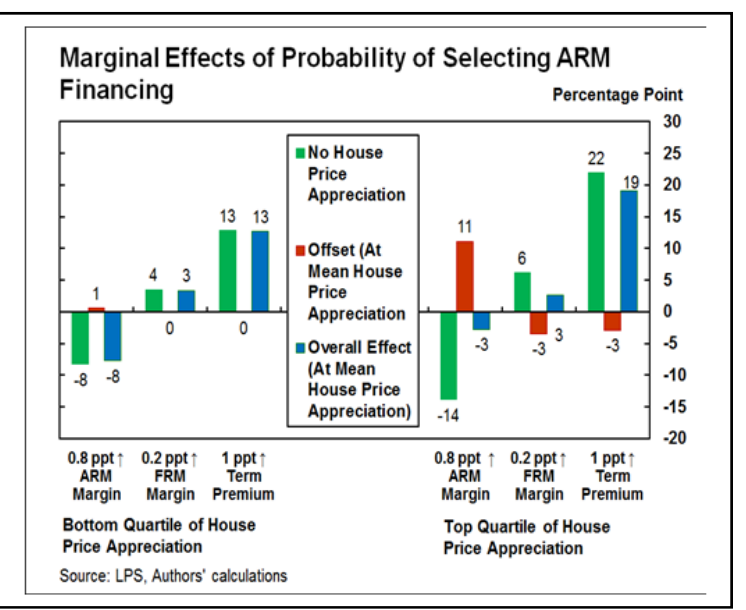

Figure 8a. ARM Margin: Overall Marginal Effect by FICO Group

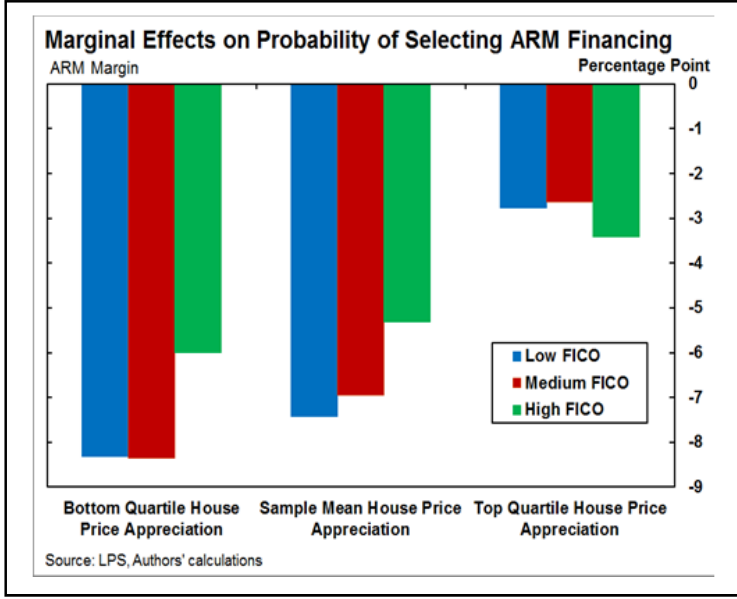

Figure 8c. Term Premium: Overall Marginal Effects by FICO Group

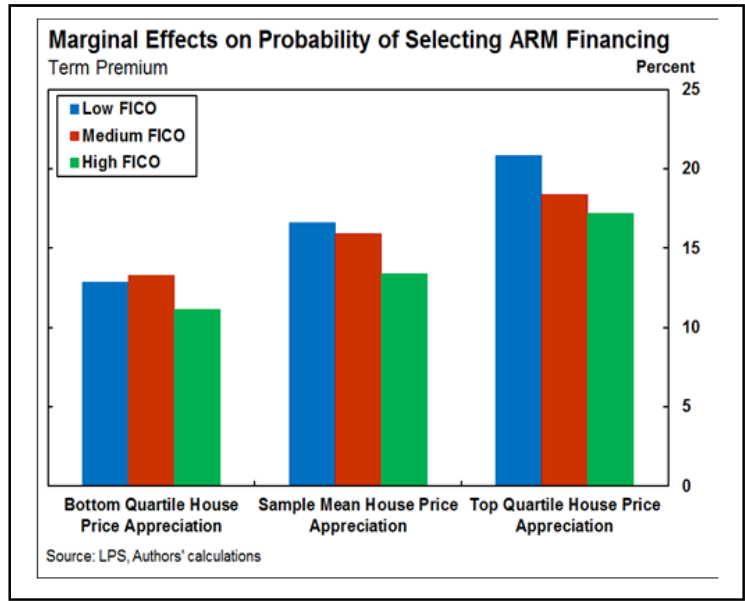

Figure 7. ARM Share by Appreciation Regime

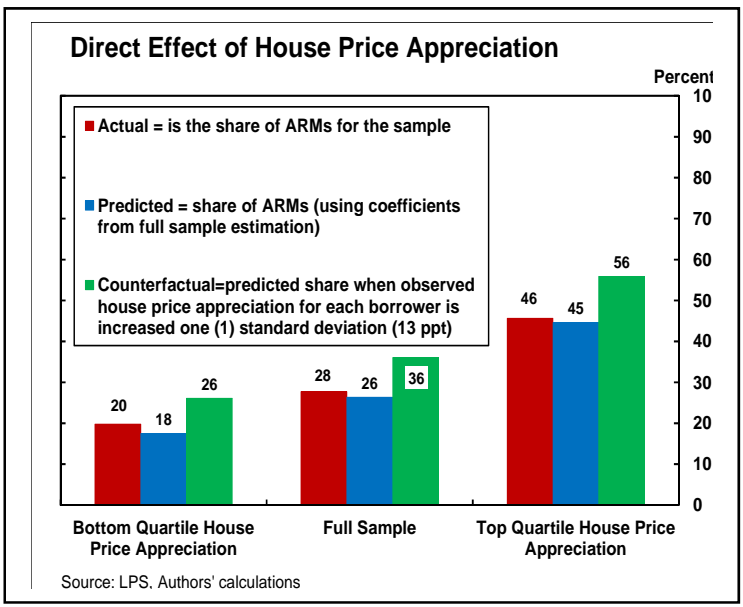

Figure 8b. FRM Margin: Overall Marginal Effects by FICO Group

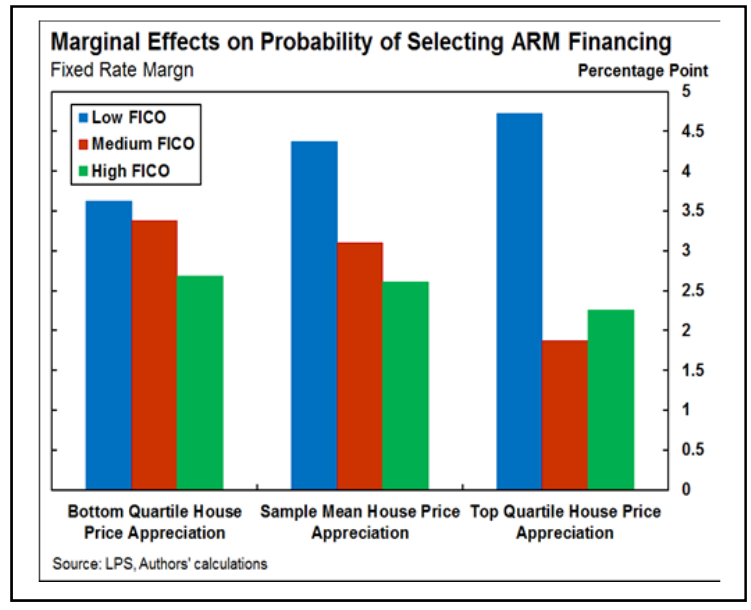

Figure 9. Actual and Fitted ARM Shares by FICO Group

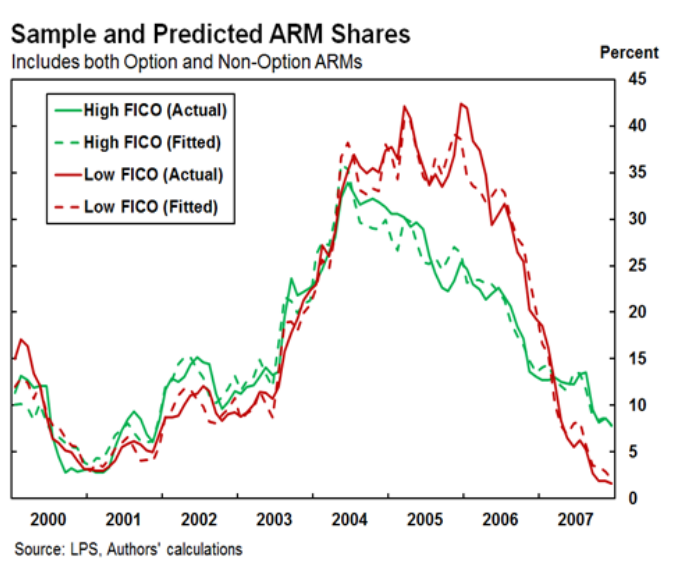


Figure 10a. Contributions to the Difference in Predicted Non-option ARM Shares

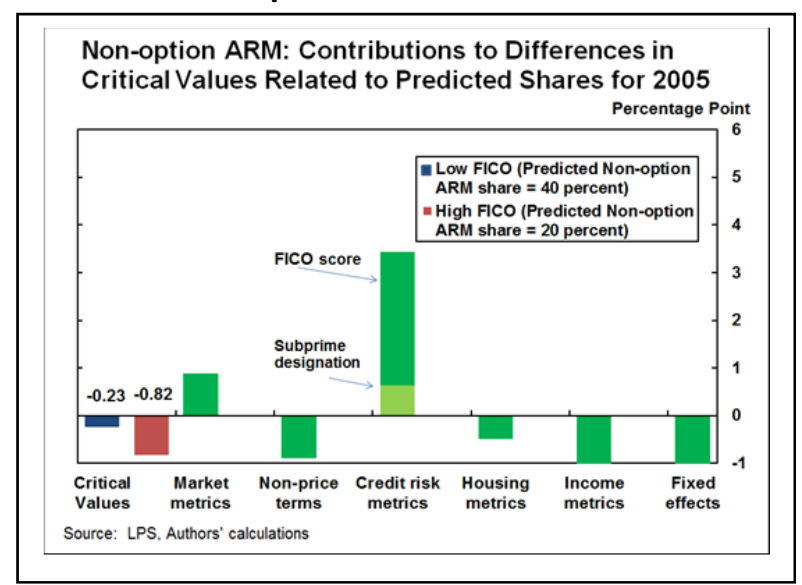

Figure 11. Fitted and Counterfactual ARM Shares by FICO Group

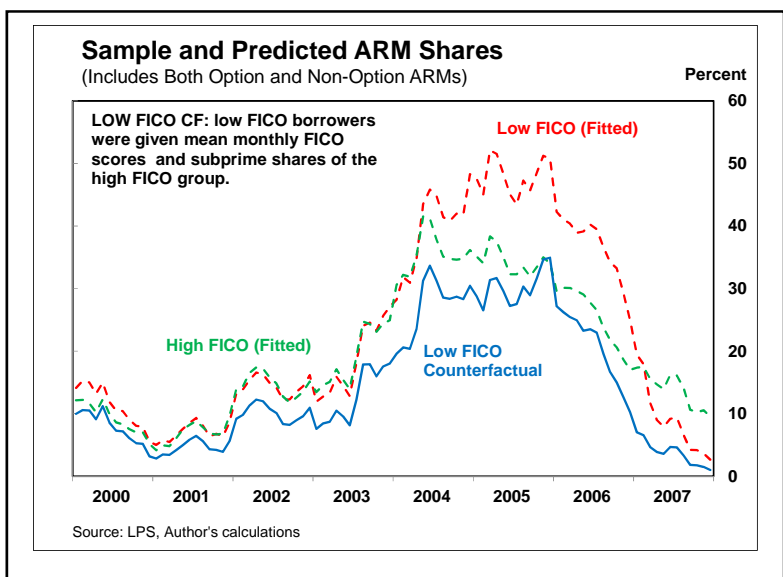

Figure 10b. Contributions to the Difference in Predicted Option ARM Shares

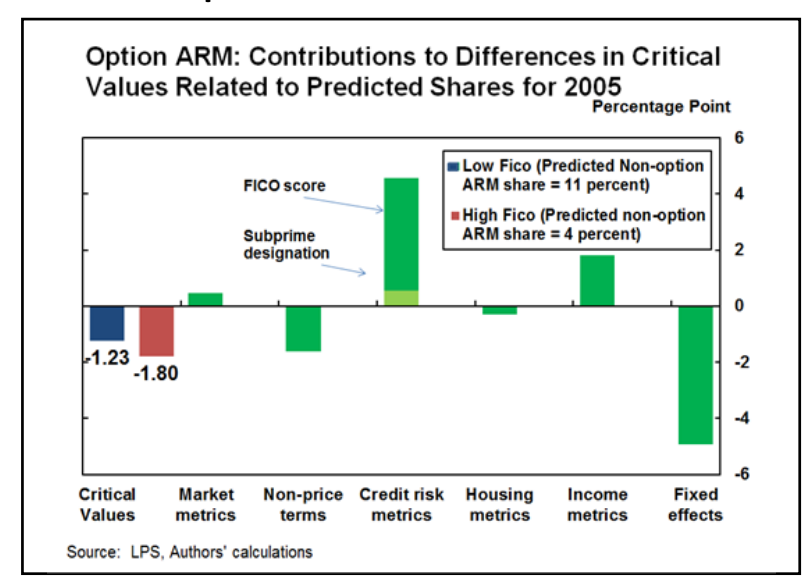

Figure 12. Marginal Effects by Sub-Sample

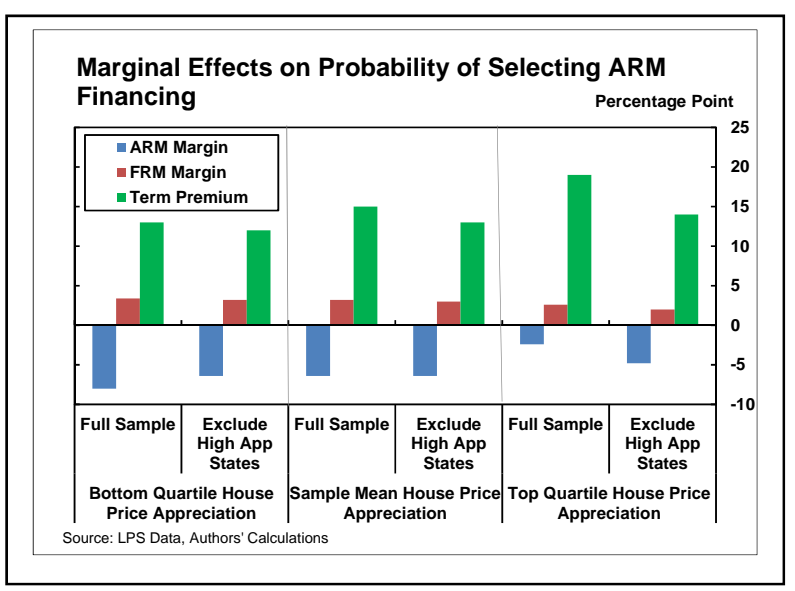




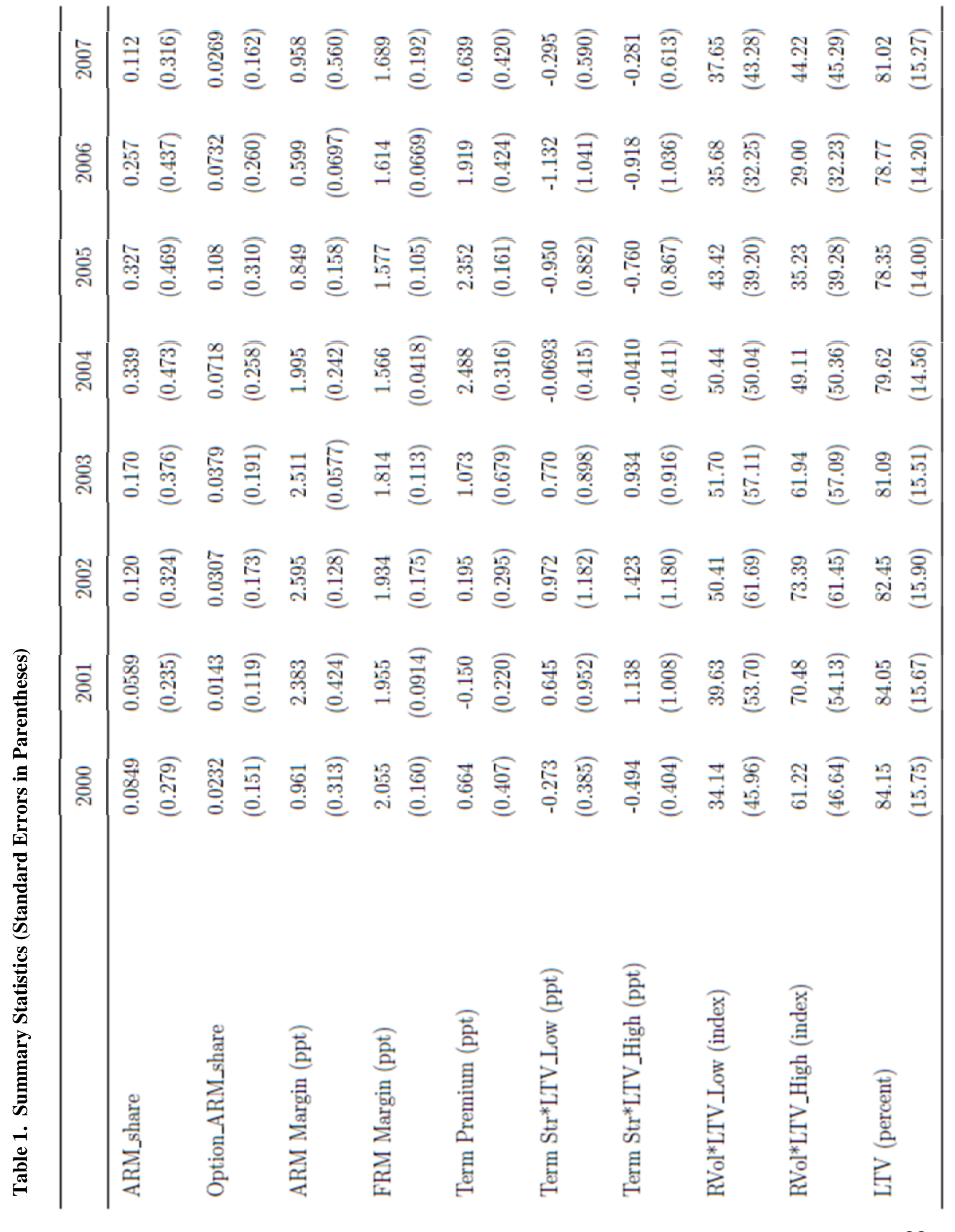




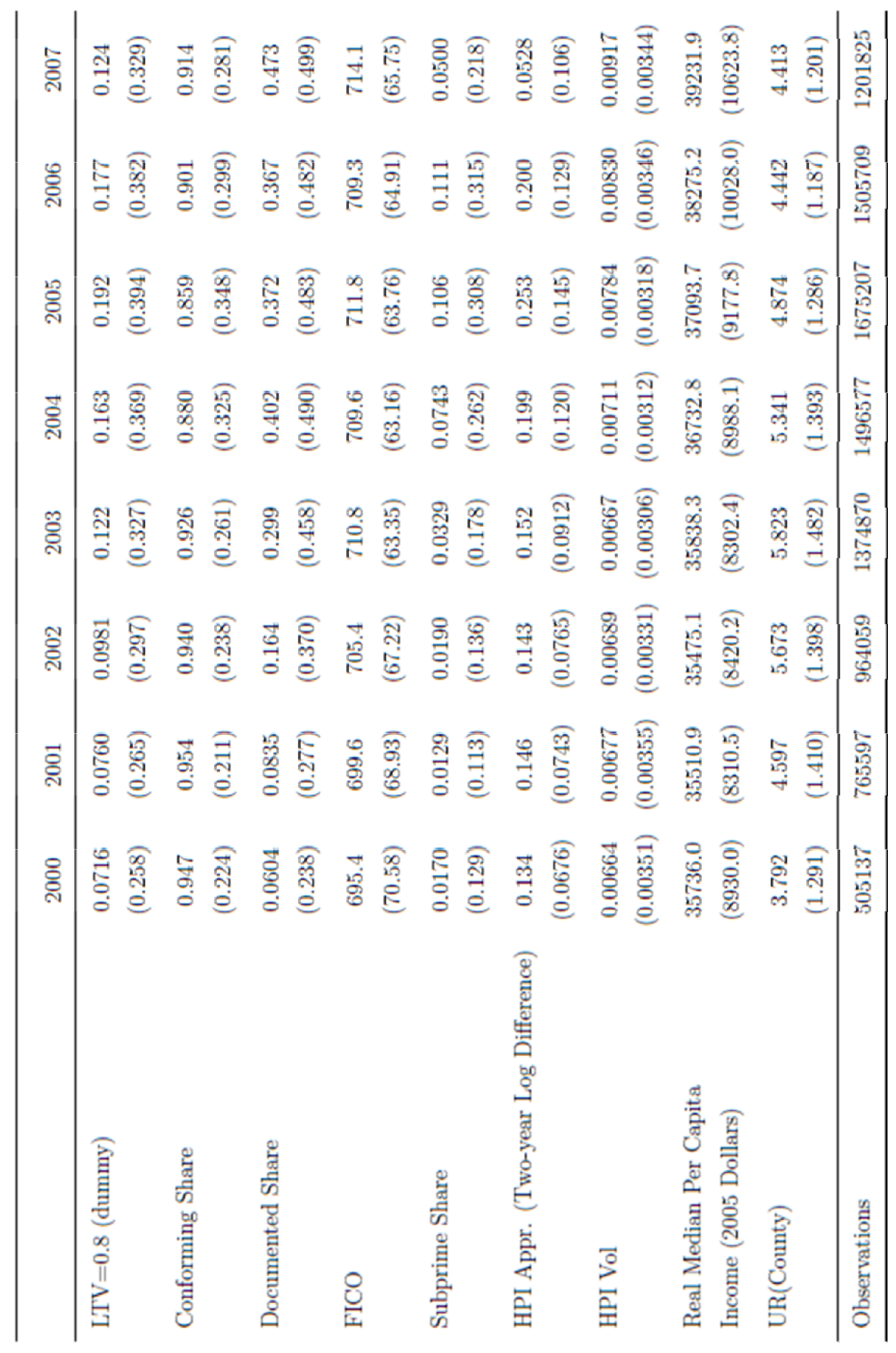


Table 2. Mortgage Choice (Purchases Only; Full Sample)

Robust Standard Errors in Parentheses; *, **, and *** denote significance at 10, 5, and 1 percent levels, respectively.

\begin{tabular}{|c|c|c|}
\hline & ARM & Option_ARM \\
\hline \multirow[t]{2}{*}{ ARM Margin } & $-0.692^{* * *}$ & $-0.288^{* * *}$ \\
\hline & $(0.0276)$ & $(0.0333)$ \\
\hline \multirow[t]{2}{*}{ ARM Margin*HPI } & $1.484^{* * *}$ & $1.027^{* * *}$ \\
\hline & $(0.183)$ & $(0.166)$ \\
\hline \multirow[t]{2}{*}{ FRM Margin } & $1.119^{* * *}$ & $0.780^{* * *}$ \\
\hline & $(0.0452)$ & $(0.0734)$ \\
\hline \multirow[t]{2}{*}{ FRM Margin*HPI } & $-1.672^{* * *}$ & $-1.757^{* * *}$ \\
\hline & $(0.237)$ & $(0.302)$ \\
\hline \multirow[t]{2}{*}{ Term Premium } & $0.835^{* * *}$ & $0.471^{* * *}$ \\
\hline & $(0.0179)$ & $(0.0241)$ \\
\hline \multirow[t]{2}{*}{ Term Premium *HPI } & $-0.309^{* *}$ & -0.219 \\
\hline & $(0.116)$ & $(0.117)$ \\
\hline \multirow[t]{2}{*}{ Term Str*LTV_Low } & $0.511^{* * *}$ & $0.187^{* * *}$ \\
\hline & $(0.0211)$ & $(0.0263)$ \\
\hline \multirow[t]{2}{*}{ Term Str*LTV_Low*HPI } & $-1.048^{* * *}$ & $-0.961^{* * *}$ \\
\hline & $(0.142)$ & $(0.131)$ \\
\hline \multirow[t]{2}{*}{ Term Str*LTV_High } & $0.637^{* * *}$ & $0.324^{* * *}$ \\
\hline & $(0.0237)$ & $(0.0301)$ \\
\hline \multirow[t]{2}{*}{ Term Str*LTV_High*HPI } & $-1.215^{* * *}$ & $-1.149^{* * *}$ \\
\hline & $(0.163)$ & $(0.141)$ \\
\hline \multirow[t]{2}{*}{ RVol*LTV_Low } & $0.00386^{* * *}$ & $0.00327^{* * *}$ \\
\hline & $(0.000431)$ & $(0.000608)$ \\
\hline \multirow[t]{2}{*}{ RVol*LTV_Low*HPI } & $-0.0259^{* * *}$ & $-0.0124^{* * *}$ \\
\hline & $(0.00210)$ & $(0.00275)$ \\
\hline
\end{tabular}




\begin{tabular}{|c|c|c|}
\hline & ARM & Option_ARM \\
\hline RVol*LTV_High & $\begin{array}{c}-0.00348^{* * *} \\
(0.000363)\end{array}$ & $\begin{array}{r}-0.00503^{* * *} \\
(0.000614)\end{array}$ \\
\hline RVol*LTV_High*HPI & $\begin{array}{c}-0.0221^{* * *} \\
(0.00213)\end{array}$ & $\begin{array}{r}-0.0102^{* * *} \\
(0.00288)\end{array}$ \\
\hline LTV & $\begin{array}{l}0.0153^{* * *} \\
(0.000586)\end{array}$ & $\begin{array}{r}0.0107^{* * *} \\
(0.000538)\end{array}$ \\
\hline $\mathrm{LTV}=0.8$ & $\begin{array}{l}0.796^{* * *} \\
(0.0166)\end{array}$ & $\begin{array}{l}0.878^{* * *} \\
(0.0188)\end{array}$ \\
\hline Conforming & $\begin{array}{c}-0.958^{* * *} \\
(0.0312)\end{array}$ & $\begin{array}{r}-1.074^{* * *} \\
(0.0268)\end{array}$ \\
\hline Documented & $\begin{array}{l}-0.117^{* * *} \\
(0.00964)\end{array}$ & $\begin{array}{r}-0.00632 \\
(0.0212)\end{array}$ \\
\hline $\mathrm{FICO}$ & $\begin{array}{c}-0.000670^{* * *} \\
(0.0000665)\end{array}$ & $\begin{array}{r}-0.00278^{* * *} \\
(0.000157)\end{array}$ \\
\hline Subprime & $\begin{array}{l}1.693^{* * *} \\
(0.0248)\end{array}$ & $\begin{array}{l}1.438^{* * *} \\
(0.0556)\end{array}$ \\
\hline HPI Appr.(Two-year Log Difference) & $\begin{array}{c}3.703^{* * *} \\
(0.508)\end{array}$ & $\begin{array}{r}3.633^{* * *} \\
(0.515)\end{array}$ \\
\hline HPI Vol & $\begin{array}{c}0.747 \\
(2.919)\end{array}$ & $\begin{array}{c}-3.854 \\
(3.918)\end{array}$ \\
\hline Log Real Inc. & $\begin{array}{l}0.833^{* * *} \\
(0.0618)\end{array}$ & $\begin{array}{l}0.904^{* * *} \\
(0.0660)\end{array}$ \\
\hline UR(County) & $\begin{array}{l}-0.0133 \\
(0.0130)\end{array}$ & $\begin{array}{c}0.0493^{* *} \\
(0.0170)\end{array}$ \\
\hline year_2000 & $\begin{array}{c}-0.312^{* * *} \\
(0.0377)\end{array}$ & $\begin{array}{l}-0.0972^{*} \\
(0.0478)\end{array}$ \\
\hline
\end{tabular}




\begin{tabular}{lcc}
\hline & ARM & Option_ARM \\
\hline year_2001 & $-0.166^{* * *}$ & -0.0792 \\
& $(0.0409)$ & $(0.0557)$ \\
year_2002 & $0.0871^{*}$ & $0.275^{* * *}$ \\
& $(0.0347)$ & $(0.0464)$ \\
year_2003 & -0.0378 & $0.0921^{*}$ \\
year_2004 & $(0.0311)$ & $(0.0379)$ \\
& $0.191^{* * *}$ & $0.202^{* * *}$ \\
year_2005 & $(0.0286)$ & $(0.0314)$ \\
& $0.117^{* * *}$ & $0.270^{* * *}$ \\
year_2006 & $(0.0230)$ & $(0.0297)$ \\
& $0.0490^{*}$ & $0.0698^{* *}$ \\
Constant & $(0.0203)$ & $(0.0257)$ \\
\hline
\end{tabular}

Standard errors in parentheses

test

${ }^{*} p<0.05, \cdots p<0.01, \cdots p<0.001$ 
Table 3a. Mortgage Choice by FICO Group.

Non-Option ARM vs. FRM Choice. Robust Standard Errors in Parentheses; *, **, and *** denote significance at 10,5 , and 1 percent levels, respectively.

\begin{tabular}{|c|c|c|c|c|c|}
\hline & LOW FICO & MED FICO & HIGH FICO & MED-HIGH & LOW-HIGH \\
\hline \multicolumn{6}{|l|}{ ARM } \\
\hline ARM Margin & $\begin{array}{c}-0.849^{* * *} \\
(0.0417)\end{array}$ & $\begin{array}{c}-0.736^{* * *} \\
(0.0317)\end{array}$ & $\begin{array}{c}-0.542^{* * *} \\
(0.0365)\end{array}$ & $\begin{array}{c}-0.195^{* * *} \\
(0.0305)\end{array}$ & $\begin{array}{c}-0.308^{* * *} \\
(0.0569)\end{array}$ \\
\hline ARM Margin*HPI & $\begin{array}{c}2.016^{* * *} \\
(0.228)\end{array}$ & $\begin{array}{c}1.587^{* * *} \\
(0.215)\end{array}$ & $\begin{array}{c}0.997^{* * *} \\
(0.182)\end{array}$ & $\begin{array}{c}0.590^{* * *} \\
(0.167)\end{array}$ & $\begin{array}{c}1.019^{* * *} \\
(0.269)\end{array}$ \\
\hline FRM Margin & $\begin{array}{l}1.311^{* * *} \\
(0.0679)\end{array}$ & $\begin{array}{l}1.127^{* * *} \\
(0.0525)\end{array}$ & $\begin{array}{l}0.934^{* * *} \\
(0.0574)\end{array}$ & $\begin{array}{l}0.193^{* * *} \\
(0.0471)\end{array}$ & $\begin{array}{l}0.377^{* * *} \\
(0.0787)\end{array}$ \\
\hline FRM Margin*HPI & $\begin{array}{c}-1.168^{* * *} \\
(0.354)\end{array}$ & $\begin{array}{c}-2.084^{* * *} \\
(0.266)\end{array}$ & $\begin{array}{c}-1.301^{* * *} \\
(0.291)\end{array}$ & $\begin{array}{c}-0.784^{* *} \\
(0.245)\end{array}$ & $\begin{array}{c}0.133 \\
(0.406)\end{array}$ \\
\hline Term Premium & $\begin{array}{c}0.959^{* * *} \\
(0.0242)\end{array}$ & $\begin{array}{l}0.859^{* * *} \\
(0.0207)\end{array}$ & $\begin{array}{l}0.755^{* * *} \\
(0.0202)\end{array}$ & $\begin{array}{l}0.104^{* * *} \\
(0.0163)\end{array}$ & $\begin{array}{l}0.204^{* * *} \\
(0.0272)\end{array}$ \\
\hline Term Premium *HPI & $\begin{array}{c}-0.439^{* *} \\
(0.155)\end{array}$ & $\begin{array}{c}-0.446^{* * *} \\
(0.132)\end{array}$ & $\begin{array}{l}-0.198 \\
(0.120)\end{array}$ & $\begin{array}{c}-0.248^{* *} \\
(0.0910)\end{array}$ & $\begin{array}{l}-0.240 \\
(0.171)\end{array}$ \\
\hline Term Str*LTV_Low & $\begin{array}{l}0.469^{* * *} \\
(0.0267)\end{array}$ & $\begin{array}{l}0.545^{* * *} \\
(0.0254)\end{array}$ & $\begin{array}{c}0.504^{* * *} \\
(0.0248)\end{array}$ & $\begin{array}{l}0.0409 * \\
(0.0205)\end{array}$ & $\begin{array}{l}-0.0348 \\
(0.0358)\end{array}$ \\
\hline Term Str*LTV_Low*HPI & $\begin{array}{c}-1.216^{* * *} \\
(0.159)\end{array}$ & $\begin{array}{c}-1.175^{* * *} \\
(0.167)\end{array}$ & $\begin{array}{c}-0.825^{* * *} \\
(0.144)\end{array}$ & $\begin{array}{c}-0.350^{* *} \\
(0.117)\end{array}$ & $\begin{array}{c}-0.390^{*} \\
(0.197)\end{array}$ \\
\hline Term Str*LTV_High & $\begin{array}{c}0.646^{* * *} \\
(0.0311)\end{array}$ & $\begin{array}{c}0.690^{* * *} \\
(0.0265)\end{array}$ & $\begin{array}{c}0.584^{* * *} \\
(0.0256)\end{array}$ & $\begin{array}{l}0.106^{* * *} \\
(0.0202)\end{array}$ & $\begin{array}{c}0.0615 \\
(0.0379)\end{array}$ \\
\hline Term Str*LTV_High*HPI & $\begin{array}{c}-1.413^{* * *} \\
(0.184)\end{array}$ & $\begin{array}{c}-1.374^{* * *} \\
(0.183)\end{array}$ & $\begin{array}{c}-1.020^{* * *} \\
(0.154)\end{array}$ & $\begin{array}{c}-0.354^{* *} \\
(0.112)\end{array}$ & $\begin{array}{c}-0.394^{*} \\
(0.199)\end{array}$ \\
\hline RVol*LTV_Low & $\begin{array}{c}0.00209^{* *} \\
(0.000807)\end{array}$ & $\begin{array}{l}0.00432^{* * *} \\
(0.000451)\end{array}$ & $\begin{array}{c}0.00112^{*} \\
(0.000473)\end{array}$ & $\begin{array}{l}0.00320^{* * *} \\
(0.000428)\end{array}$ & $\begin{array}{c}0.000969 \\
(0.000884)\end{array}$ \\
\hline RVol*LTV_Low*HPI & $\begin{array}{c}-0.0229^{* * *} \\
(0.00394)\end{array}$ & $\begin{array}{c}-0.0267^{* * *} \\
(0.00228)\end{array}$ & $\begin{array}{c}-0.0194^{* * *} \\
(0.00257)\end{array}$ & $\begin{array}{c}-0.00723^{* * *} \\
(0.00201)\end{array}$ & $\begin{array}{l}-0.00346 \\
(0.00468)\end{array}$ \\
\hline
\end{tabular}




\begin{tabular}{|c|c|c|c|c|c|}
\hline & LOW FICO & MED FICO & HIGH FICO & MED-HIGH & LOW-HIGH \\
\hline RVol*LTV_High & $\begin{array}{c}-0.00382^{* * *} \\
(0.000655)\end{array}$ & $\begin{array}{c}-0.00309^{* * *} \\
(0.000392)\end{array}$ & $\begin{array}{c}-0.00347^{* * *} \\
(0.000468)\end{array}$ & $\begin{array}{c}0.000381 \\
(0.000407)\end{array}$ & $\begin{array}{l}-0.000351 \\
(0.000792)\end{array}$ \\
\hline RVol*LTV_High*HPI & $\begin{array}{c}-0.0186^{* * *} \\
(0.00368)\end{array}$ & $\begin{array}{c}-0.0241^{* * *} \\
(0.00237)\end{array}$ & $\begin{array}{c}-0.0148^{* * *} \\
(0.00270)\end{array}$ & $\begin{array}{c}-0.00929^{* * *} \\
(0.00203)\end{array}$ & $\begin{array}{l}-0.00377 \\
(0.00464)\end{array}$ \\
\hline LTV & $\begin{array}{c}0.00338^{* * *} \\
(0.000820)\end{array}$ & $\begin{array}{c}0.0171^{* * *} \\
(0.000634)\end{array}$ & $\begin{array}{c}0.0159^{* * *} \\
(0.000473)\end{array}$ & $\begin{array}{c}0.00117^{* * *} \\
(0.000314)\end{array}$ & $\begin{array}{l}-0.0125^{* * *} \\
(0.000700)\end{array}$ \\
\hline $\mathrm{LTV}=0.8$ & $\begin{array}{c}0.986^{* * *} \\
(0.0167)\end{array}$ & $\begin{array}{c}0.790^{* * *} \\
(0.0174)\end{array}$ & $\begin{array}{l}0.425^{* * *} \\
(0.0207)\end{array}$ & $\begin{array}{c}0.365^{* * *} \\
(0.0102)\end{array}$ & $\begin{array}{c}0.561^{* * *} \\
(0.0240)\end{array}$ \\
\hline Conforming & $\begin{array}{c}-0.940^{* * *} \\
(0.0304)\end{array}$ & $\begin{array}{c}-0.905^{* * *} \\
(0.0325)\end{array}$ & $\begin{array}{c}-1.044^{* * *} \\
(0.0294)\end{array}$ & $\begin{array}{c}0.139^{* * *} \\
(0.00911)\end{array}$ & $\begin{array}{l}0.105^{* * *} \\
(0.0173)\end{array}$ \\
\hline Documented & $\begin{array}{c}-0.283^{* * *} \\
(0.0105)\end{array}$ & $\begin{array}{l}-0.100^{* * *} \\
(0.00960)\end{array}$ & $\begin{array}{c}-0.0310^{*} \\
(0.0137)\end{array}$ & $\begin{array}{c}-0.0692^{* * *} \\
(0.00875)\end{array}$ & $\begin{array}{c}-0.252^{* * *} \\
(0.0151)\end{array}$ \\
\hline FICO & $\begin{array}{c}-0.000692^{* * *} \\
(0.000141)\end{array}$ & $\begin{array}{c}-0.000391^{* * *} \\
(0.0000861)\end{array}$ & $\begin{array}{c}-0.00493^{* * *} \\
(0.000184)\end{array}$ & $\begin{array}{c}0.00454^{* * *} \\
(0.000177)\end{array}$ & $\begin{array}{c}0.00424^{* * *} \\
(0.000279)\end{array}$ \\
\hline Subprime & $\begin{array}{l}1.918^{* * *} \\
(0.0227)\end{array}$ & $\begin{array}{l}1.440^{* * *} \\
(0.0211)\end{array}$ & $\begin{array}{l}1.212^{* * *} \\
(0.0262)\end{array}$ & $\begin{array}{c}0.228^{* * *} \\
(0.0223)\end{array}$ & $\begin{array}{c}0.706^{* * *} \\
(0.0316)\end{array}$ \\
\hline HPI Appr.(Two-year Log Difference) & $\begin{array}{l}1.869^{* *} \\
(0.590)\end{array}$ & $\begin{array}{c}4.542^{* * *} \\
(0.567)\end{array}$ & $\begin{array}{c}3.116^{* * *} \\
(0.588)\end{array}$ & $\begin{array}{c}1.425^{* * *} \\
(0.342)\end{array}$ & $\begin{array}{l}-1.247 \\
(0.642)\end{array}$ \\
\hline HPI Vol & $\begin{array}{c}-8.260^{* *} \\
(3.021)\end{array}$ & $\begin{array}{l}-0.780 \\
(3.043)\end{array}$ & $\begin{array}{l}8.061^{* *} \\
(2.815)\end{array}$ & $\begin{array}{c}-8.841^{* * *} \\
(1.290)\end{array}$ & $\begin{array}{c}-16.32^{* * *} \\
(2.464)\end{array}$ \\
\hline Log Real Inc. & $\begin{array}{l}0.705^{* * *} \\
(0.0549)\end{array}$ & $\begin{array}{c}0.889^{* * *} \\
(0.0668)\end{array}$ & $\begin{array}{l}0.834^{* * *} \\
(0.0675)\end{array}$ & $\begin{array}{l}0.0550^{*} \\
(0.0228)\end{array}$ & $\begin{array}{l}-0.129^{*} \\
(0.0557)\end{array}$ \\
\hline UR(County) & $\begin{array}{l}-0.0129 \\
(0.0112)\end{array}$ & $\begin{array}{l}-0.0166 \\
(0.0142)\end{array}$ & $\begin{array}{r}-0.00928 \\
(0.0136)\end{array}$ & $\begin{array}{l}-0.00729 \\
(0.00435)\end{array}$ & $\begin{array}{r}-0.00362 \\
(0.0101)\end{array}$ \\
\hline year_2000 & $\begin{array}{c}0.0788 \\
(0.0467)\end{array}$ & $\begin{array}{c}-0.405^{* * *} \\
(0.0403)\end{array}$ & $\begin{array}{c}-0.463^{* * *} \\
(0.0318)\end{array}$ & $\begin{array}{c}0.0577^{*} \\
(0.0244)\end{array}$ & $\begin{array}{l}0.542^{* * *} \\
(0.0363)\end{array}$ \\
\hline
\end{tabular}




\begin{tabular}{lccccc}
\hline & LOW FICO & MED FICO & HIGH FICO & MED-HIGH & LOW-HIGH \\
\hline year_2001 & $0.340^{* * *}$ & $-0.255^{* * *}$ & $-0.330^{* * *}$ & $0.0750^{* * *}$ & $0.670^{* * *}$ \\
& $(0.0546)$ & $(0.0420)$ & $(0.0340)$ & $(0.0227)$ & $(0.0425)$ \\
year_2002 & $0.604^{* * *}$ & 0.00327 & $-0.0964^{* *}$ & $0.0997^{* * *}$ & $0.701^{* * *}$ \\
& $(0.0496)$ & $(0.0360)$ & $(0.0319)$ & $(0.0239)$ & $(0.0456)$ \\
year_2003 & $0.347^{* * *}$ & $-0.0872^{* *}$ & $-0.202^{* * *}$ & $0.115^{* * *}$ & $0.549^{* * *}$ \\
& $(0.0427)$ & $(0.0327)$ & $(0.0313)$ & $(0.0226)$ & $(0.0417)$ \\
year_2004 & $0.473^{* * *}$ & $0.174^{* * *}$ & 0.0453 & $0.129^{* * *}$ & $0.428^{* * *}$ \\
& $(0.0379)$ & $(0.0316)$ & $(0.0282)$ & $(0.0224)$ & $(0.0376)$ \\
year_2005 & $0.363^{* * *}$ & $0.0914^{* * *}$ & -0.0264 & $0.118^{* * *}$ & $0.390^{* * *}$ \\
& $(0.0285)$ & $(0.0265)$ & $(0.0234)$ & $(0.0175)$ & $(0.0288)$ \\
year_2006 & $0.265^{* * *}$ & 0.00371 & $-0.0449^{*}$ & $0.0486^{* *}$ & $0.310^{* * *}$ \\
& $(0.0273)$ & $(0.0238)$ & $(0.0193)$ & $(0.0153)$ & $(0.0264)$ \\
\hline Constant & $-10.48^{* * *}$ & $-13.20^{* * *}$ & $-8.518^{* * *}$ & & $(0.767)$ \\
\hline
\end{tabular}

Standard errors in parentheses

$\cdot p<0.05, \cdots p<0.01, \cdots p<0.001$ 
Table 3b. Mortgage Choice (Purchases Only; Full Sample) by FICO Group.

Option ARM vs. FRM

Robust Standard Errors in Parentheses; *, **, and *** denote significance at 10, 5, and 1 percent levels, respectively.

\begin{tabular}{|c|c|c|c|c|c|}
\hline & LOW FICO & MED FICO & HIGH FICO & MED-HIGH & LOW-HIGH \\
\hline \multicolumn{6}{|l|}{ Option_ARM } \\
\hline ARM Margin & $\begin{array}{c}-0.372^{* * *} \\
(0.0645)\end{array}$ & $\begin{array}{c}-0.277^{* * *} \\
(0.0394)\end{array}$ & $\begin{array}{c}-0.299^{* * *} \\
(0.0503)\end{array}$ & $\begin{array}{c}0.0216 \\
(0.0521)\end{array}$ & $\begin{array}{l}-0.0733 \\
(0.0855)\end{array}$ \\
\hline ARM Margin*HPI & $\begin{array}{c}1.597^{* * *} \\
(0.285)\end{array}$ & $\begin{array}{c}0.927^{* * *} \\
(0.199)\end{array}$ & $\begin{array}{c}0.868^{* * *} \\
(0.215)\end{array}$ & $\begin{array}{l}0.0594 \\
(0.217)\end{array}$ & $\begin{array}{l}0.729^{*} \\
(0.349)\end{array}$ \\
\hline FRM Margin & $\begin{array}{c}1.133^{* * *} \\
(0.106)\end{array}$ & $\begin{array}{l}0.707^{* * *} \\
(0.0803)\end{array}$ & $\begin{array}{l}0.639^{* * *} \\
(0.0913)\end{array}$ & $\begin{array}{c}0.0679 \\
(0.0775)\end{array}$ & $\begin{array}{c}0.494^{* * *} \\
(0.106)\end{array}$ \\
\hline FRM Margin*HPI & $\begin{array}{c}-2.207^{* * *} \\
(0.436)\end{array}$ & $\begin{array}{c}-1.680^{* * *} \\
(0.318)\end{array}$ & $\begin{array}{c}-1.443^{* * *} \\
(0.340)\end{array}$ & $\begin{array}{l}-0.237 \\
(0.283)\end{array}$ & $\begin{array}{l}-0.764^{*} \\
(0.382)\end{array}$ \\
\hline Term Premium & $\begin{array}{l}0.564^{* * *} \\
(0.0332)\end{array}$ & $\begin{array}{l}0.465^{* * *} \\
(0.0300)\end{array}$ & $\begin{array}{l}0.483^{* * *} \\
(0.0308)\end{array}$ & $\begin{array}{l}-0.0176 \\
(0.0281)\end{array}$ & $\begin{array}{c}0.0811 \\
(0.0421)\end{array}$ \\
\hline Term Premium *HPI & $\begin{array}{c}-0.526^{* *} \\
(0.171)\end{array}$ & $\begin{array}{l}-0.251 \\
(0.139)\end{array}$ & $\begin{array}{l}-0.194 \\
(0.139)\end{array}$ & $\begin{array}{l}-0.0568 \\
(0.123)\end{array}$ & $\begin{array}{l}-0.332 \\
(0.208)\end{array}$ \\
\hline Term Str*LTV_Low & $\begin{array}{l}0.252^{* * *} \\
(0.0459)\end{array}$ & $\begin{array}{l}0.167^{* * *} \\
(0.0328)\end{array}$ & $\begin{array}{l}0.239^{* * *} \\
(0.0364)\end{array}$ & $\begin{array}{l}-0.0720^{*} \\
(0.0325)\end{array}$ & $\begin{array}{c}0.0137 \\
(0.0619)\end{array}$ \\
\hline Term Str*LTV_Low*HPI & $\begin{array}{c}-1.390^{* * *} \\
(0.207)\end{array}$ & $\begin{array}{c}-0.889^{* * *} \\
(0.159)\end{array}$ & $\begin{array}{c}-0.778^{* * *} \\
(0.174)\end{array}$ & $\begin{array}{l}-0.111 \\
(0.142)\end{array}$ & $\begin{array}{l}-0.612^{*} \\
(0.289)\end{array}$ \\
\hline Term Str*LTV_High & $\begin{array}{l}0.340^{* * *} \\
(0.0507)\end{array}$ & $\begin{array}{l}0.285^{* * *} \\
(0.0345)\end{array}$ & $\begin{array}{l}0.331^{* * *} \\
(0.0379)\end{array}$ & $\begin{array}{l}-0.0465 \\
(0.0342)\end{array}$ & $\begin{array}{l}0.00873 \\
(0.0636)\end{array}$ \\
\hline Term Str*LTV_High*HPI & $\begin{array}{c}-1.357^{* * *} \\
(0.219)\end{array}$ & $\begin{array}{c}-1.103^{* * *} \\
(0.164)\end{array}$ & $\begin{array}{c}-1.020^{* * *} \\
(0.179)\end{array}$ & $\begin{array}{l}-0.0836 \\
(0.153)\end{array}$ & $\begin{array}{l}-0.338 \\
(0.289)\end{array}$ \\
\hline RVol*LTV_Low & $\begin{array}{c}0.00180^{*} \\
(0.000888)\end{array}$ & $\begin{array}{c}0.00363^{* * *} \\
(0.000647)\end{array}$ & $\begin{array}{c}0.00225^{* *} \\
(0.000713)\end{array}$ & $\begin{array}{c}0.00138^{*} \\
(0.000625)\end{array}$ & $\begin{array}{l}-0.000442 \\
(0.000983)\end{array}$ \\
\hline RVol*LTV_Low*HPI & $\begin{array}{c}-0.00795^{*} \\
(0.00399)\end{array}$ & $\begin{array}{c}-0.0145^{* * *} \\
(0.00295)\end{array}$ & $\begin{array}{c}-0.0118^{* * *} \\
(0.00347)\end{array}$ & $\begin{array}{l}-0.00273 \\
(0.00310)\end{array}$ & $\begin{array}{c}0.00383 \\
(0.00457)\end{array}$ \\
\hline
\end{tabular}




\begin{tabular}{|c|c|c|c|c|c|}
\hline & LOW FICO & MED FICO & HIGH FICO & MED-HIGH & LOW-HIGH \\
\hline RVol*LTV_High & $\begin{array}{c}-0.00718^{* * *} \\
(0.000729)\end{array}$ & $\begin{array}{c}-0.00328^{* * *} \\
(0.000687)\end{array}$ & $\begin{array}{c}-0.00311^{* * *} \\
(0.000736)\end{array}$ & $\begin{array}{l}-0.000168 \\
(0.000623)\end{array}$ & $\begin{array}{c}-0.00407^{* * *} \\
(0.000844)\end{array}$ \\
\hline RVol*LTV_High*HPI & $\begin{array}{l}-0.00497 \\
(0.00376)\end{array}$ & $\begin{array}{c}-0.0133^{* * *} \\
(0.00308)\end{array}$ & $\begin{array}{c}-0.00900^{*} \\
(0.00367)\end{array}$ & $\begin{array}{l}-0.00435 \\
(0.00286)\end{array}$ & $\begin{array}{c}0.00403 \\
(0.00452)\end{array}$ \\
\hline LTV & $\begin{array}{c}-0.00199^{*} \\
(0.000962)\end{array}$ & $\begin{array}{l}0.0104^{* * *} \\
(0.000565)\end{array}$ & $\begin{array}{l}0.0152^{* * *} \\
(0.000466)\end{array}$ & $\begin{array}{c}-0.00482^{* * *} \\
(0.000411)\end{array}$ & $\begin{array}{l}-0.0172^{* * *} \\
(0.000917)\end{array}$ \\
\hline $\mathrm{LTV}=0.8$ & $\begin{array}{l}1.201^{* * *} \\
(0.0305)\end{array}$ & $\begin{array}{l}0.714^{* * *} \\
(0.0191)\end{array}$ & $\begin{array}{l}0.485^{* * *} \\
(0.0176)\end{array}$ & $\begin{array}{c}0.229^{* * *} \\
(0.0133)\end{array}$ & $\begin{array}{l}0.716^{* * *} \\
(0.0288)\end{array}$ \\
\hline Conforming & $\begin{array}{c}-1.288^{* * *} \\
(0.0402)\end{array}$ & $\begin{array}{c}-1.070^{* * *} \\
(0.0276)\end{array}$ & $\begin{array}{c}-0.948^{* * *} \\
(0.0237)\end{array}$ & $\begin{array}{c}-0.122^{* * *} \\
(0.0124)\end{array}$ & $\begin{array}{c}-0.340^{* * *} \\
(0.0268)\end{array}$ \\
\hline Documented & $\begin{array}{c}-0.0555^{* *} \\
(0.0209)\end{array}$ & $\begin{array}{l}-0.0314 \\
(0.0218)\end{array}$ & $\begin{array}{c}0.0984^{* * *} \\
(0.0251)\end{array}$ & $\begin{array}{l}-0.130^{* * *} \\
(0.00955)\end{array}$ & $\begin{array}{c}-0.154^{* * *} \\
(0.0206)\end{array}$ \\
\hline FICO & $\begin{array}{c}-0.00173^{* * *} \\
(0.000266)\end{array}$ & $\begin{array}{c}-0.00312^{* * *} \\
(0.000205)\end{array}$ & $\begin{array}{c}-0.00719^{* * *} \\
(0.000190)\end{array}$ & $\begin{array}{c}0.00406^{* * *} \\
(0.000243)\end{array}$ & $\begin{array}{c}0.00545^{* * *} \\
(0.000378)\end{array}$ \\
\hline Subprime & $\begin{array}{l}1.673^{* * *} \\
(0.0494)\end{array}$ & $\begin{array}{l}1.293^{* * *} \\
(0.0663)\end{array}$ & $\begin{array}{l}0.814^{* * *} \\
(0.0684)\end{array}$ & $\begin{array}{l}0.479^{* * *} \\
(0.0305)\end{array}$ & $\begin{array}{l}0.860^{* * *} \\
(0.0442)\end{array}$ \\
\hline HPI Appr.(Two-year Log Difference) & $\begin{array}{c}3.042^{* * *} \\
(0.605)\end{array}$ & $\begin{array}{c}4.079^{* * *} \\
(0.585)\end{array}$ & $\begin{array}{c}3.345^{* * *} \\
(0.629)\end{array}$ & $\begin{array}{c}0.734 \\
(0.469)\end{array}$ & $\begin{array}{l}-0.302 \\
(0.578)\end{array}$ \\
\hline HPI Vol & $\begin{array}{c}-12.75^{* *} \\
(4.340)\end{array}$ & $\begin{array}{l}-4.396 \\
(4.113)\end{array}$ & $\begin{array}{c}4.666 \\
(3.901)\end{array}$ & $\begin{array}{c}-9.062^{* * *} \\
(1.692)\end{array}$ & $\begin{array}{c}-17.41^{* * *} \\
(3.577)\end{array}$ \\
\hline Log Real Inc. & $\begin{array}{l}0.958^{* * *} \\
(0.0760)\end{array}$ & $\begin{array}{l}0.958^{* * *} \\
(0.0680)\end{array}$ & $\begin{array}{l}0.805^{* * *} \\
(0.0664)\end{array}$ & $\begin{array}{l}0.153^{* * *} \\
(0.0291)\end{array}$ & $\begin{array}{c}0.153^{*} \\
(0.0633)\end{array}$ \\
\hline UR(County) & $\begin{array}{c}0.0775^{* * *} \\
(0.0191)\end{array}$ & $\begin{array}{c}0.0462^{* *} \\
(0.0174)\end{array}$ & $\begin{array}{c}0.0296 \\
(0.0160)\end{array}$ & $\begin{array}{l}0.0166^{* *} \\
(0.00646)\end{array}$ & $\begin{array}{c}0.0480^{* * *} \\
(0.0130)\end{array}$ \\
\hline year_2000 & $\begin{array}{l}0.609^{* * *} \\
(0.0718)\end{array}$ & $\begin{array}{c}-0.249^{* * *} \\
(0.0520)\end{array}$ & $\begin{array}{c}-0.312^{* * *} \\
(0.0431)\end{array}$ & $\begin{array}{c}0.0626 \\
(0.0357)\end{array}$ & $\begin{array}{c}0.921^{* * *} \\
(0.0559)\end{array}$ \\
\hline
\end{tabular}




\begin{tabular}{lccccc}
\hline & LOW FICO & MED FICO & HIGH FICO & MED-HIGH & LOW-HIGH \\
\hline year_2001 & $0.899^{* * *}$ & $-0.328^{* * *}$ & $-0.555^{* * *}$ & $0.227^{* * *}$ & $1.454^{* * *}$ \\
& $(0.0868)$ & $(0.0540)$ & $(0.0472)$ & $(0.0400)$ & $(0.0674)$ \\
year_2002 & $1.178^{* * *}$ & $0.116^{*}$ & $-0.127^{* *}$ & $0.243^{* * *}$ & $1.305^{* * *}$ \\
& $(0.0768)$ & $(0.0489)$ & $(0.0441)$ & $(0.0346)$ & $(0.0678)$ \\
year_2003 & $0.823^{* * *}$ & -0.0144 & $-0.206^{* * *}$ & $0.191^{* * *}$ & $1.029^{* * *}$ \\
& $(0.0603)$ & $(0.0423)$ & $(0.0399)$ & $(0.0357)$ & $(0.0581)$ \\
year_2004 & $0.784^{* * *}$ & $0.114^{* * *}$ & -0.00483 & $0.119^{* * *}$ & $0.789^{* * *}$ \\
& $(0.0526)$ & $(0.0345)$ & $(0.0339)$ & $(0.0307)$ & $(0.0489)$ \\
year_2005 & $0.791^{* * *}$ & $0.196^{* * *}$ & $0.0766^{*}$ & $0.119^{* * *}$ & $0.715^{* * *}$ \\
& $(0.0486)$ & $(0.0323)$ & $(0.0320)$ & $(0.0209)$ & $(0.0438)$ \\
year_2006 & $0.435^{* * *}$ & 0.00169 & 0.00555 & -0.00386 & $0.430^{* * *}$ \\
& $(0.0426)$ & $(0.0293)$ & $(0.0264)$ & $(0.0189)$ & $(0.0385)$ \\
Constant & $-13.06^{* * *}$ & $-12.36^{* * *}$ & $-7.697^{* * *}$ & & $(0.777)$ \\
\hline Observations & $(0.917)$ & $(0.784)$ & &
\end{tabular}


Table 4a. Mortgage Choice by House Price Appreciation

Non-Option ARM vs. FRM Choice.

High Appreciation Subsample includes AZ, CA, FL, HI, MD, NV \& CA.

Robust Standard Errors in Parentheses; *, **, and *** denote significance at 10, 5, and 1 percent levels respectively.

\begin{tabular}{|c|c|c|c|c|}
\hline & High Appr. & Low Appr. & Full Sample & Low App.-High App. \\
\hline \multicolumn{5}{|l|}{ ARM } \\
\hline ARM Margin & $\begin{array}{c}-0.712^{* * *} \\
(0.0750)\end{array}$ & $\begin{array}{c}-0.617^{* * *} \\
(0.0286)\end{array}$ & $\begin{array}{c}-0.692^{* * *} \\
(0.0276)\end{array}$ & $\begin{array}{c}0.0954 \\
(0.0802)\end{array}$ \\
\hline ARM Margin*HPI & $\begin{array}{c}2.187^{* * *} \\
(0.312)\end{array}$ & $\begin{array}{c}1.010^{* * *} \\
(0.233)\end{array}$ & $\begin{array}{c}1.484^{* * *} \\
(0.183)\end{array}$ & $\begin{array}{c}-1.177^{* *} \\
(0.388)\end{array}$ \\
\hline FRM Margin & $\begin{array}{c}1.226^{* * *} \\
(0.106)\end{array}$ & $\begin{array}{l}1.240^{* * *} \\
(0.0558)\end{array}$ & $\begin{array}{l}1.119^{* * *} \\
(0.0452)\end{array}$ & $\begin{array}{l}0.0136 \\
(0.119)\end{array}$ \\
\hline FRM Margin*HPI & $\begin{array}{c}-2.042^{* * *} \\
(0.403)\end{array}$ & $\begin{array}{c}-2.790^{* * *} \\
(0.393)\end{array}$ & $\begin{array}{c}-1.672^{* * *} \\
(0.237)\end{array}$ & $\begin{array}{l}-0.748 \\
(0.562)\end{array}$ \\
\hline Term Premium & $\begin{array}{l}0.793^{* * *} \\
(0.0562)\end{array}$ & $\begin{array}{l}0.887^{* * *} \\
(0.0195)\end{array}$ & $\begin{array}{l}0.835^{* * *} \\
(0.0179)\end{array}$ & $\begin{array}{c}0.0942 \\
(0.0594)\end{array}$ \\
\hline Term Premium *HPI & $\begin{array}{l}-0.408 \\
(0.248)\end{array}$ & $\begin{array}{c}-0.794^{* * *} \\
(0.167)\end{array}$ & $\begin{array}{c}-0.309^{* *} \\
(0.116)\end{array}$ & $\begin{array}{l}-0.386 \\
(0.298)\end{array}$ \\
\hline Term Str*LTV_Low & $\begin{array}{l}0.403^{* * *} \\
(0.0693)\end{array}$ & $\begin{array}{l}0.502^{* * *} \\
(0.0192)\end{array}$ & $\begin{array}{l}0.511^{* * *} \\
(0.0211)\end{array}$ & $\begin{array}{c}0.0992 \\
(0.0718)\end{array}$ \\
\hline Term Str*LTV_Low*HPI & $\begin{array}{c}-1.050^{* * *} \\
(0.305)\end{array}$ & $\begin{array}{c}-0.981^{* * *} \\
(0.169)\end{array}$ & $\begin{array}{c}-1.048^{* * *} \\
(0.142)\end{array}$ & $\begin{array}{l}0.0697 \\
(0.348)\end{array}$ \\
\hline Term Str*LTV_High & $\begin{array}{l}0.539^{* * *} \\
(0.0727)\end{array}$ & $\begin{array}{l}0.613^{* * *} \\
(0.0214)\end{array}$ & $\begin{array}{l}0.637^{* * *} \\
(0.0237)\end{array}$ & $\begin{array}{c}0.0738 \\
(0.0757)\end{array}$ \\
\hline Term Str*LTV_High*HPI & $\begin{array}{c}-1.247^{* * *} \\
(0.324)\end{array}$ & $\begin{array}{c}-1.045^{* * *} \\
(0.187)\end{array}$ & $\begin{array}{c}-1.215^{* * *} \\
(0.163)\end{array}$ & $\begin{array}{c}0.202 \\
(0.374)\end{array}$ \\
\hline RVol*LTV_Low & $\begin{array}{l}0.00678^{* * *} \\
(0.000774)\end{array}$ & $\begin{array}{l}0.00175^{* *} \\
(0.000550)\end{array}$ & $\begin{array}{l}0.00386^{* * *} \\
(0.000431)\end{array}$ & $\begin{array}{c}-0.00502^{* * *} \\
(0.000949)\end{array}$ \\
\hline RVol*LTV_Low*HPI & $\begin{array}{c}-0.0264^{* * *} \\
(0.00266)\end{array}$ & $\begin{array}{c}-0.0178^{* * *} \\
(0.00412)\end{array}$ & $\begin{array}{c}-0.0259^{* * *} \\
(0.00210)\end{array}$ & $\begin{array}{c}0.00868 \\
(0.00490)\end{array}$ \\
\hline
\end{tabular}




\begin{tabular}{|c|c|c|c|c|}
\hline & High Appr. & Low Appr. & Full Sample & Low App.-High App. \\
\hline RVol*LTV_High & $\begin{array}{l}-0.00212^{* *} \\
(0.000720)\end{array}$ & $\begin{array}{c}-0.00504^{* * *} \\
(0.000515)\end{array}$ & $\begin{array}{c}-0.00348^{* * *} \\
(0.000363)\end{array}$ & $\begin{array}{c}-0.00292^{* * *} \\
(0.000884)\end{array}$ \\
\hline RVol*LTV_High*HPI & $\begin{array}{c}-0.0224^{* * *} \\
(0.00289)\end{array}$ & $\begin{array}{l}-0.0108^{* *} \\
(0.00402)\end{array}$ & $\begin{array}{c}-0.0221^{* * *} \\
(0.00213)\end{array}$ & $\begin{array}{c}0.0116^{*} \\
(0.00495)\end{array}$ \\
\hline LTV & $\begin{array}{c}0.0196^{* * *} \\
(0.000756)\end{array}$ & $\begin{array}{c}0.0126^{* * *} \\
(0.000675)\end{array}$ & $\begin{array}{c}0.0153^{* * *} \\
(0.000586)\end{array}$ & $\begin{array}{c}-0.00700^{* * *} \\
(0.00101)\end{array}$ \\
\hline $\mathrm{LTV}=0.8$ & $\begin{array}{l}0.902^{* * *} \\
(0.0257)\end{array}$ & $\begin{array}{l}0.729^{* * *} \\
(0.0185)\end{array}$ & $\begin{array}{c}0.796^{* * *} \\
(0.0166)\end{array}$ & $\begin{array}{c}-0.173^{* * *} \\
(0.0316)\end{array}$ \\
\hline Conforming & $\begin{array}{c}-0.826^{* * *} \\
(0.0360)\end{array}$ & $\begin{array}{c}-1.089^{* * *} \\
(0.0330)\end{array}$ & $\begin{array}{c}-0.958^{* * *} \\
(0.0312)\end{array}$ & $\begin{array}{c}-0.263^{* * *} \\
(0.0488)\end{array}$ \\
\hline Documented & $\begin{array}{c}-0.162^{* * *} \\
(0.0139)\end{array}$ & $\begin{array}{c}-0.0922^{* * *} \\
(0.0116)\end{array}$ & $\begin{array}{l}-0.117^{* * *} \\
(0.00964)\end{array}$ & $\begin{array}{c}0.0698^{* * *} \\
(0.0181)\end{array}$ \\
\hline FICO & $\begin{array}{c}-0.000379^{* * *} \\
(0.000114)\end{array}$ & $\begin{array}{c}-0.000776^{* * *} \\
(0.0000851)\end{array}$ & $\begin{array}{c}-0.000670^{* * *} \\
(0.0000665)\end{array}$ & $\begin{array}{c}-0.000397^{* *} \\
(0.000142)\end{array}$ \\
\hline Subprime & $\begin{array}{l}1.390^{* * *} \\
(0.0276)\end{array}$ & $\begin{array}{l}1.840^{* * *} \\
(0.0230)\end{array}$ & $\begin{array}{l}1.693^{* * *} \\
(0.0248)\end{array}$ & $\begin{array}{c}0.449^{* * *} \\
(0.0359)\end{array}$ \\
\hline HPI Appr.(Two-year Log Difference) & $\begin{array}{c}3.446^{* * *} \\
(0.662)\end{array}$ & $\begin{array}{c}6.350^{* * *} \\
(0.771)\end{array}$ & $\begin{array}{c}3.703^{* * *} \\
(0.508)\end{array}$ & $\begin{array}{l}2.905^{* *} \\
(1.015)\end{array}$ \\
\hline HPI Vol & $\begin{array}{c}3.291 \\
(5.707)\end{array}$ & $\begin{array}{c}-8.969^{* *} \\
(3.194)\end{array}$ & $\begin{array}{c}0.747 \\
(2.919)\end{array}$ & $\begin{array}{l}-12.26 \\
(6.529)\end{array}$ \\
\hline Log Real Inc. & $\begin{array}{c}0.632^{* * *} \\
(0.109)\end{array}$ & $\begin{array}{c}0.914^{* * *} \\
(0.0589)\end{array}$ & $\begin{array}{l}0.833^{* * *} \\
(0.0618)\end{array}$ & $\begin{array}{l}0.282^{*} \\
(0.123)\end{array}$ \\
\hline UR(County) & $\begin{array}{c}-0.0507^{* *} \\
(0.0189)\end{array}$ & $\begin{array}{l}0.0295^{*} \\
(0.0127)\end{array}$ & $\begin{array}{l}-0.0133 \\
(0.0130)\end{array}$ & $\begin{array}{c}0.0802^{* * *} \\
(0.0227)\end{array}$ \\
\hline year_2000 & $\begin{array}{c}-0.777^{* * *} \\
(0.0572)\end{array}$ & $\begin{array}{c}-0.0755^{*} \\
(0.0361)\end{array}$ & $\begin{array}{c}-0.312^{* * *} \\
(0.0377)\end{array}$ & $\begin{array}{l}0.701^{* * *} \\
(0.0676)\end{array}$ \\
\hline
\end{tabular}




\begin{tabular}{lcccc}
\hline & High Appr. & Low Appr. & Full Sample & Low App.-High App. \\
\hline year_2001 & $-0.577^{* * *}$ & 0.0263 & $-0.166^{* * *}$ & $0.603^{* * *}$ \\
& $(0.0623)$ & $(0.0353)$ & $(0.0409)$ & $(0.0715)$ \\
year_2002 & $-0.176^{* *}$ & $0.213^{* * *}$ & $0.0871^{*}$ & $0.389^{* * *}$ \\
& $(0.0621)$ & $(0.0338)$ & $(0.0347)$ & $(0.0705)$ \\
year_2003 & $-0.218^{* * *}$ & 0.0252 & -0.0378 & $0.243^{* * *}$ \\
& $(0.0570)$ & $(0.0321)$ & $(0.0311)$ & $(0.0653)$ \\
year_2004 & -0.0000700 & $0.263^{* * *}$ & $0.191^{* * *}$ & $0.263^{* * *}$ \\
& $(0.0544)$ & $(0.0282)$ & $(0.0286)$ & $(0.0612)$ \\
year_2005 & 0.0752 & $0.178^{* * *}$ & $0.117^{* * *}$ & $0.102^{*}$ \\
& $(0.0432)$ & $(0.0235)$ & $(0.0230)$ & $(0.0491)$ \\
year_2006 & 0.00482 & $0.0934^{* * *}$ & $0.0490^{*}$ & $0.0885^{*}$ \\
& $(0.0338)$ & $(0.0181)$ & $(0.0203)$ & $(0.0383)$ \\
Constant & $-10.36^{* * *}$ & $-13.15^{* * *}$ & $-12.34^{* * *}$ & \\
& $(1.298)$ & $(0.689)$ & $(0.725)$ & \\
\hline Observations & 3286017 & 6202964 & 9488981 & \\
\hline
\end{tabular}

Standard errors in parentheses

${ }^{-} p<0.05, \cdots p<0.01, \cdots p<0.001$ 
Table 4b. Mortgage Choice by House Price Appreciation (Option ARM vs. FRM)

High Appreciation Subsample includes AZ, CA, FL, HI, MD, NV \& CA. Robust Standard Errors in Parentheses; *, **, and $* * *$ denote significance at 10,5 , and 1 percent levels, respectively.

\begin{tabular}{|c|c|c|c|c|}
\hline & High Appr. & Low Appr. & Full Sample & Low App.-High App. \\
\hline \multicolumn{5}{|l|}{ Option_ARM } \\
\hline ARM Margin & $\begin{array}{c}-0.287^{* * *} \\
(0.0661)\end{array}$ & $\begin{array}{c}-0.268^{* * *} \\
(0.0440)\end{array}$ & $\begin{array}{c}-0.288^{* * *} \\
(0.0333)\end{array}$ & $\begin{array}{c}0.0192 \\
(0.0793)\end{array}$ \\
\hline ARM Margin*HPI & $\begin{array}{c}1.373^{* * *} \\
(0.196)\end{array}$ & $\begin{array}{c}1.178^{* * *} \\
(0.315)\end{array}$ & $\begin{array}{c}1.027^{* * *} \\
(0.166)\end{array}$ & $\begin{array}{l}-0.195 \\
(0.371)\end{array}$ \\
\hline FRM Margin & $\begin{array}{c}1.308^{* * *} \\
(0.151)\end{array}$ & $\begin{array}{l}0.826^{* * *} \\
(0.0748)\end{array}$ & $\begin{array}{c}0.780^{* * *} \\
(0.0734)\end{array}$ & $\begin{array}{c}-0.482^{* *} \\
(0.168)\end{array}$ \\
\hline FRM Margin*HPI & $\begin{array}{c}-3.149^{* * *} \\
(0.479)\end{array}$ & $\begin{array}{c}-3.004^{* * *} \\
(0.459)\end{array}$ & $\begin{array}{c}-1.757^{* * *} \\
(0.302)\end{array}$ & $\begin{array}{c}0.144 \\
(0.662)\end{array}$ \\
\hline Term Premium & $\begin{array}{l}0.514^{* * *} \\
(0.0552)\end{array}$ & $\begin{array}{l}0.467^{* * *} \\
(0.0260)\end{array}$ & $\begin{array}{l}0.471^{* * *} \\
(0.0241)\end{array}$ & $\begin{array}{l}-0.0476 \\
(0.0609)\end{array}$ \\
\hline Term Premium *HPI & $\begin{array}{l}-0.519^{*} \\
(0.215)\end{array}$ & $\begin{array}{l}-0.438^{*} \\
(0.185)\end{array}$ & $\begin{array}{l}-0.219 \\
(0.117)\end{array}$ & $\begin{array}{l}0.0808 \\
(0.283)\end{array}$ \\
\hline Term Str*LTV_Low & $\begin{array}{c}0.0528 \\
(0.0542)\end{array}$ & $\begin{array}{l}0.177^{* * *} \\
(0.0275)\end{array}$ & $\begin{array}{l}0.187^{* * *} \\
(0.0263)\end{array}$ & $\begin{array}{c}0.124^{*} \\
(0.0607)\end{array}$ \\
\hline Term Str*LTV_Low*HPI & $\begin{array}{c}-0.808^{* * *} \\
(0.197)\end{array}$ & $\begin{array}{c}-0.937^{* * *} \\
(0.188)\end{array}$ & $\begin{array}{c}-0.961^{* * *} \\
(0.131)\end{array}$ & $\begin{array}{l}-0.129 \\
(0.272)\end{array}$ \\
\hline Term Str*LTV_High & $\begin{array}{l}0.231^{* * *} \\
(0.0605)\end{array}$ & $\begin{array}{l}0.293^{* * *} \\
(0.0351)\end{array}$ & $\begin{array}{l}0.324^{* * *} \\
(0.0301)\end{array}$ & $\begin{array}{c}0.0616 \\
(0.0699)\end{array}$ \\
\hline Term Str*LTV_High*HPI & $\begin{array}{c}-1.071^{* * *} \\
(0.215)\end{array}$ & $\begin{array}{c}-1.018^{* * *} \\
(0.227)\end{array}$ & $\begin{array}{c}-1.149^{* * *} \\
(0.141)\end{array}$ & $\begin{array}{l}0.0527 \\
(0.313)\end{array}$ \\
\hline RVol*LTV_Low & $\begin{array}{l}0.00471^{* * *} \\
(0.000907)\end{array}$ & $\begin{array}{c}0.00149^{*} \\
(0.000703)\end{array}$ & $\begin{array}{l}0.00327^{* * *} \\
(0.000608)\end{array}$ & $\begin{array}{c}-0.00322^{* *} \\
(0.00115)\end{array}$ \\
\hline RVol*LTV_Low*HPI & $\begin{array}{c}-0.0133^{* * *} \\
(0.00290)\end{array}$ & $\begin{array}{l}-0.00199 \\
(0.00428)\end{array}$ & $\begin{array}{c}-0.0124^{* * *} \\
(0.00275)\end{array}$ & $\begin{array}{c}0.0113^{*} \\
(0.00517)\end{array}$ \\
\hline
\end{tabular}




\begin{tabular}{|c|c|c|c|c|}
\hline & High Appr. & Low Appr. & Full Sample & Low App.-High App. \\
\hline RVol*LTV_High & $\begin{array}{c}-0.00634^{* * *} \\
(0.000961)\end{array}$ & $\begin{array}{c}-0.00522^{* * *} \\
(0.000608)\end{array}$ & $\begin{array}{c}-0.00503^{* * *} \\
(0.000614)\end{array}$ & $\begin{array}{c}0.00113 \\
(0.00114)\end{array}$ \\
\hline RVol*LTV_High*HPI & $\begin{array}{c}-0.00731^{*} \\
(0.00306)\end{array}$ & $\begin{array}{l}-0.00221 \\
(0.00423)\end{array}$ & $\begin{array}{c}-0.0102^{* * *} \\
(0.00288)\end{array}$ & $\begin{array}{c}0.00511 \\
(0.00522)\end{array}$ \\
\hline LTV & $\begin{array}{c}0.0156^{* * *} \\
(0.000551)\end{array}$ & $\begin{array}{c}0.00670^{* * *} \\
(0.000633)\end{array}$ & $\begin{array}{c}0.0107^{* * *} \\
(0.000538)\end{array}$ & $\begin{array}{c}-0.00894^{* * *} \\
(0.000838)\end{array}$ \\
\hline $\mathrm{LTV}=0.8$ & $\begin{array}{l}1.007^{* * *} \\
(0.0308)\end{array}$ & $\begin{array}{l}0.781^{* * *} \\
(0.0221)\end{array}$ & $\begin{array}{c}0.878^{* * *} \\
(0.0188)\end{array}$ & $\begin{array}{c}-0.226^{* * *} \\
(0.0378)\end{array}$ \\
\hline Conforming & $\begin{array}{c}-0.961^{* * *} \\
(0.0343)\end{array}$ & $\begin{array}{c}-1.145^{* * *} \\
(0.0268)\end{array}$ & $\begin{array}{c}-1.074^{* * *} \\
(0.0268)\end{array}$ & $\begin{array}{c}-0.184^{* * *} \\
(0.0435)\end{array}$ \\
\hline Documented & $\begin{array}{c}-0.169^{* * *} \\
(0.0192)\end{array}$ & $\begin{array}{c}0.149^{* * *} \\
(0.0162)\end{array}$ & $\begin{array}{r}-0.00632 \\
(0.0212)\end{array}$ & $\begin{array}{l}0.319^{* * *} \\
(0.0251)\end{array}$ \\
\hline FICO & $\begin{array}{c}-0.00271^{* * *} \\
(0.000313)\end{array}$ & $\begin{array}{l}-0.00261^{* * *} \\
(0.0001000)\end{array}$ & $\begin{array}{c}-0.00278^{* * *} \\
(0.000157)\end{array}$ & $\begin{array}{c}0.000101 \\
(0.000328)\end{array}$ \\
\hline Subprime & $\begin{array}{l}1.036^{* * *} \\
(0.0773)\end{array}$ & $\begin{array}{l}1.691^{* * *} \\
(0.0302)\end{array}$ & $\begin{array}{l}1.438^{* * *} \\
(0.0556)\end{array}$ & $\begin{array}{c}0.655^{* * *} \\
(0.0829)\end{array}$ \\
\hline HPI Appr.(Two-year Log Difference) & $\begin{array}{c}5.883^{* * *} \\
(0.762)\end{array}$ & $\begin{array}{c}5.545^{* * *} \\
(0.732)\end{array}$ & $\begin{array}{c}3.633^{* * *} \\
(0.515)\end{array}$ & $\begin{array}{l}-0.338 \\
(1.055)\end{array}$ \\
\hline HPI Vol & $\begin{array}{l}-10.39 \\
(8.047)\end{array}$ & $\begin{array}{l}-9.795^{*} \\
(4.069)\end{array}$ & $\begin{array}{l}-3.854 \\
(3.918)\end{array}$ & $\begin{array}{c}0.599 \\
(9.003)\end{array}$ \\
\hline Log Real Inc. & $\begin{array}{c}0.848^{* * *} \\
(0.123)\end{array}$ & $\begin{array}{c}0.915^{* * *} \\
(0.0650)\end{array}$ & $\begin{array}{c}0.904^{* * *} \\
(0.0660)\end{array}$ & $\begin{array}{l}0.0675 \\
(0.139)\end{array}$ \\
\hline UR(County) & $\begin{array}{c}0.0183 \\
(0.0227)\end{array}$ & $\begin{array}{l}0.111^{* * *} \\
(0.0161)\end{array}$ & $\begin{array}{c}0.0493^{* *} \\
(0.0170)\end{array}$ & $\begin{array}{c}0.0927^{* * *} \\
(0.0277)\end{array}$ \\
\hline year_2000 & $\begin{array}{c}-0.565^{* * *} \\
(0.0932)\end{array}$ & $\begin{array}{c}0.176^{* * *} \\
(0.0405)\end{array}$ & $\begin{array}{l}-0.0972^{*} \\
(0.0478)\end{array}$ & $\begin{array}{c}0.741^{* * *} \\
(0.101)\end{array}$ \\
\hline
\end{tabular}




\begin{tabular}{lcccc}
\hline & High Appr. & Low Appr. & Full Sample & Low App.-High App. \\
\hline year_2001 & $-0.519^{* * *}$ & $0.171^{* * *}$ & -0.0792 & $0.690^{* * *}$ \\
& $(0.105)$ & $(0.0504)$ & $(0.0557)$ & $(0.116)$ \\
year_2002 & 0.00437 & $0.410^{* * *}$ & $0.275^{* * *}$ & $0.406^{* * *}$ \\
& $(0.0995)$ & $(0.0394)$ & $(0.0464)$ & $(0.107)$ \\
year_2003 & -0.0752 & $0.121^{* * *}$ & $0.0921^{*}$ & $0.196^{*}$ \\
& $(0.0857)$ & $(0.0343)$ & $(0.0379)$ & $(0.0921)$ \\
year_2004 & 0.0110 & $0.255^{* * *}$ & $0.202^{* * *}$ & $0.244^{* *}$ \\
& $(0.0702)$ & $(0.0296)$ & $(0.0314)$ & $(0.0761)$ \\
year_2005 & $0.174^{*}$ & $0.317^{* * *}$ & $0.270^{* * *}$ & $0.144^{*}$ \\
& $(0.0690)$ & $(0.0234)$ & $(0.0297)$ & $(0.0727)$ \\
year_2006 & -0.0421 & $0.114^{* * *}$ & $0.0698^{* *}$ & $0.156^{* *}$ \\
& $(0.0523)$ & $(0.0183)$ & $(0.0257)$ & $(0.0553)$ \\
Constant & $-12.09^{* * *}$ & $-12.38^{* * *}$ & $-12.17^{* * *}$ & \\
\hline Observations & $(1.387)$ & $(0.772)$ & $(0.764)$ & \\
\hline
\end{tabular}

Standard errors in parentheses

${ }^{*} p<0.05, \cdots p<0.01, \cdots p<0.001$ 
Table 5a. Mortgage Choice for Sample Excluding AZ, CA, FL, HI, MD, NV \& CA by FICO Non-Option ARM vs. FRM Choice.

Robust Standard Errors in Parentheses; *, **, and *** denote significance at 10, 5, and 1 percent levels, respectively.

\begin{tabular}{|c|c|c|c|c|c|}
\hline & LOW FICO & MED FICO & HIGH FICO & MED-HIGH & LOW-HIGH \\
\hline \multicolumn{6}{|l|}{ ARM } \\
\hline ARM Margin & $\begin{array}{c}-0.799^{* * *} \\
(0.0507)\end{array}$ & $\begin{array}{c}-0.684^{* * *} \\
(0.0318)\end{array}$ & $\begin{array}{c}-0.430^{* * *} \\
(0.0375)\end{array}$ & $\begin{array}{c}-0.253^{* * *} \\
(0.0405)\end{array}$ & $\begin{array}{c}-0.368^{* * *} \\
(0.0588)\end{array}$ \\
\hline ARM Margin*HPI & $\begin{array}{c}1.724^{* * *} \\
(0.342)\end{array}$ & $\begin{array}{c}1.260^{* * *} \\
(0.254)\end{array}$ & $\begin{array}{c}0.187 \\
(0.264)\end{array}$ & $\begin{array}{c}1.072^{* * *} \\
(0.232)\end{array}$ & $\begin{array}{c}1.537^{* * *} \\
(0.362)\end{array}$ \\
\hline FRM Margin & $\begin{array}{l}1.535^{* * *} \\
(0.0826)\end{array}$ & $\begin{array}{l}1.184^{* * *} \\
(0.0684)\end{array}$ & $\begin{array}{l}0.923^{* * *} \\
(0.0685)\end{array}$ & $\begin{array}{l}0.261^{* * *} \\
(0.0656)\end{array}$ & $\begin{array}{c}0.612^{* * *} \\
(0.0843)\end{array}$ \\
\hline FRM Margin*HPI & $\begin{array}{c}-2.889^{* * *} \\
(0.563)\end{array}$ & $\begin{array}{c}-2.878^{* * *} \\
(0.437)\end{array}$ & $\begin{array}{c}-1.465^{* *} \\
(0.483)\end{array}$ & $\begin{array}{c}-1.413^{* * *} \\
(0.387)\end{array}$ & $\begin{array}{l}-1.424^{*} \\
(0.600)\end{array}$ \\
\hline Term Premium & $\begin{array}{l}1.037^{* * *} \\
(0.0272)\end{array}$ & $\begin{array}{l}0.902^{* * *} \\
(0.0229)\end{array}$ & $\begin{array}{l}0.765^{* * *} \\
(0.0232)\end{array}$ & $\begin{array}{l}0.137^{* * *} \\
(0.0222)\end{array}$ & $\begin{array}{l}0.272^{* * *} \\
(0.0300)\end{array}$ \\
\hline Term Premium *HPI & $\begin{array}{c}-1.051^{* * *} \\
(0.214)\end{array}$ & $\begin{array}{c}-0.935^{* * *} \\
(0.177)\end{array}$ & $\begin{array}{l}-0.293 \\
(0.185)\end{array}$ & $\begin{array}{c}-0.642^{* * *} \\
(0.129)\end{array}$ & $\begin{array}{c}-0.757^{* * *} \\
(0.220)\end{array}$ \\
\hline Term Str*LTV_Low & $\begin{array}{l}0.462^{* * *} \\
(0.0325)\end{array}$ & $\begin{array}{l}0.554^{* * *} \\
(0.0219)\end{array}$ & $\begin{array}{c}0.469^{* * *} \\
(0.0250)\end{array}$ & $\begin{array}{c}0.0849^{* *} \\
(0.0265)\end{array}$ & $\begin{array}{r}-0.00646 \\
(0.0396)\end{array}$ \\
\hline Term Str*LTV_Low*HPI & $\begin{array}{c}-1.317^{* * *} \\
(0.241)\end{array}$ & $\begin{array}{c}-1.235^{* * *} \\
(0.180)\end{array}$ & $\begin{array}{l}-0.418^{*} \\
(0.189)\end{array}$ & $\begin{array}{c}-0.817^{* * *} \\
(0.156)\end{array}$ & $\begin{array}{c}-0.900^{* * *} \\
(0.260)\end{array}$ \\
\hline Term Str*LTV_High & $\begin{array}{c}0.638^{* * *} \\
(0.0355)\end{array}$ & $\begin{array}{l}0.681^{* * *} \\
(0.0231)\end{array}$ & $\begin{array}{l}0.542^{* * *} \\
(0.0249)\end{array}$ & $\begin{array}{l}0.139^{* * *} \\
(0.0273)\end{array}$ & $\begin{array}{l}0.0961^{*} \\
(0.0411)\end{array}$ \\
\hline Term Str*LTV_High*HPI & $\begin{array}{c}-1.506^{* * *} \\
(0.248)\end{array}$ & $\begin{array}{c}-1.297^{* * *} \\
(0.200)\end{array}$ & $\begin{array}{c}-0.560^{* *} \\
(0.200)\end{array}$ & $\begin{array}{c}-0.737^{* * *} \\
(0.163)\end{array}$ & $\begin{array}{c}-0.946^{* * *} \\
(0.261)\end{array}$ \\
\hline RVol*LTV_Low & $\begin{array}{l}-0.00203^{*} \\
(0.000912)\end{array}$ & $\begin{array}{l}0.00234^{* * *} \\
(0.000582)\end{array}$ & $\begin{array}{c}0.000517 \\
(0.000566)\end{array}$ & $\begin{array}{c}0.00182^{* *} \\
(0.000589)\end{array}$ & $\begin{array}{l}-0.00255^{* *} \\
(0.000959)\end{array}$ \\
\hline RVol*LTV_Low*HPI & $\begin{array}{c}-0.00324 \\
(0.00638)\end{array}$ & $\begin{array}{c}-0.0191^{* * *} \\
(0.00398)\end{array}$ & $\begin{array}{c}-0.0214^{* * *} \\
(0.00409)\end{array}$ & $\begin{array}{c}0.00230 \\
(0.00379)\end{array}$ & $\begin{array}{l}0.0181^{* *} \\
(0.00648)\end{array}$ \\
\hline
\end{tabular}




\begin{tabular}{|c|c|c|c|c|c|}
\hline & LOW FICO & MED FICO & HIGH FICO & MED-HIGH & LOW-HIGH \\
\hline RVol*LTV_High & $\begin{array}{c}-0.00736^{* * *} \\
(0.000806)\end{array}$ & $\begin{array}{c}-0.00449^{* * *} \\
(0.000545)\end{array}$ & $\begin{array}{c}-0.00349^{* * *} \\
(0.000538)\end{array}$ & $\begin{array}{c}-0.00100 \\
(0.000562)\end{array}$ & $\begin{array}{c}-0.00387^{* * *} \\
(0.000838)\end{array}$ \\
\hline RVol*LTV_High*HPI & $\begin{array}{c}0.00586 \\
(0.00603)\end{array}$ & $\begin{array}{c}-0.0135^{* * *} \\
(0.00380)\end{array}$ & $\begin{array}{c}-0.0168^{* * *} \\
(0.00398)\end{array}$ & $\begin{array}{c}0.00326 \\
(0.00358)\end{array}$ & $\begin{array}{l}0.0227^{* * *} \\
(0.00600)\end{array}$ \\
\hline LTV & $\begin{array}{c}-0.0000559 \\
(0.000793)\end{array}$ & $\begin{array}{l}0.0144^{* * *} \\
(0.000751)\end{array}$ & $\begin{array}{c}0.0140^{* * *} \\
(0.000582)\end{array}$ & $\begin{array}{c}0.000366 \\
(0.000344)\end{array}$ & $\begin{array}{l}-0.0141^{* * *} \\
(0.000789)\end{array}$ \\
\hline $\mathrm{LTV}=0.8$ & $\begin{array}{c}0.934^{* * *} \\
(0.0154)\end{array}$ & $\begin{array}{l}0.706^{* * *} \\
(0.0195)\end{array}$ & $\begin{array}{l}0.386^{* * *} \\
(0.0244)\end{array}$ & $\begin{array}{c}0.320^{* * *} \\
(0.0113)\end{array}$ & $\begin{array}{c}0.547^{* * *} \\
(0.0268)\end{array}$ \\
\hline Conforming & $\begin{array}{c}-1.048^{* * *} \\
(0.0376)\end{array}$ & $\begin{array}{c}-1.046^{* * *} \\
(0.0338)\end{array}$ & $\begin{array}{c}-1.160^{* * *} \\
(0.0329)\end{array}$ & $\begin{array}{l}0.114^{* * *} \\
(0.0123)\end{array}$ & $\begin{array}{l}0.112^{* * *} \\
(0.0305)\end{array}$ \\
\hline Documented & $\begin{array}{c}-0.286^{* * *} \\
(0.0141)\end{array}$ & $\begin{array}{c}-0.0712^{* * *} \\
(0.0122)\end{array}$ & $\begin{array}{c}0.0168 \\
(0.0145)\end{array}$ & $\begin{array}{c}-0.0880^{* * *} \\
(0.00866)\end{array}$ & $\begin{array}{c}-0.303^{* * *} \\
(0.0172)\end{array}$ \\
\hline FICO & $\begin{array}{c}-0.00114^{* * *} \\
(0.000156)\end{array}$ & $\begin{array}{c}-0.000445^{* * *} \\
(0.000115)\end{array}$ & $\begin{array}{c}-0.00435^{* * *} \\
(0.000244)\end{array}$ & $\begin{array}{c}0.00390^{* * *} \\
(0.000245)\end{array}$ & $\begin{array}{c}0.00321^{* * *} \\
(0.000336)\end{array}$ \\
\hline Subprime & $\begin{array}{l}2.035^{* * *} \\
(0.0234)\end{array}$ & $\begin{array}{l}1.560^{* * *} \\
(0.0222)\end{array}$ & $\begin{array}{l}1.276^{* * *} \\
(0.0318)\end{array}$ & $\begin{array}{l}0.284^{* * *} \\
(0.0299)\end{array}$ & $\begin{array}{l}0.759^{* * *} \\
(0.0393)\end{array}$ \\
\hline HPI Appr.(Two-year Log Difference) & $\begin{array}{c}3.643^{* * *} \\
(0.921)\end{array}$ & $\begin{array}{c}6.529^{* * *} \\
(0.898)\end{array}$ & $\begin{array}{c}5.497^{* * *} \\
(0.893)\end{array}$ & $\begin{array}{c}1.031 \\
(0.600)\end{array}$ & $\begin{array}{c}-1.854^{*} \\
(0.927)\end{array}$ \\
\hline HPI Vol & $\begin{array}{c}-17.23^{* * *} \\
(3.114)\end{array}$ & $\begin{array}{c}-12.98^{* * *} \\
(3.347)\end{array}$ & $\begin{array}{c}2.118 \\
(3.420)\end{array}$ & $\begin{array}{c}-15.10^{* * *} \\
(1.449)\end{array}$ & $\begin{array}{c}-19.35^{* * *} \\
(3.208)\end{array}$ \\
\hline Log Real Inc. & $\begin{array}{l}0.687^{* * *} \\
(0.0573)\end{array}$ & $\begin{array}{l}0.990^{* * *} \\
(0.0620)\end{array}$ & $\begin{array}{l}0.966^{* * *} \\
(0.0587)\end{array}$ & $\begin{array}{c}0.0239 \\
(0.0223)\end{array}$ & $\begin{array}{c}-0.279^{* * *} \\
(0.0528)\end{array}$ \\
\hline UR(County) & $\begin{array}{l}0.0202^{*} \\
(0.0103)\end{array}$ & $\begin{array}{l}0.0305^{*} \\
(0.0141)\end{array}$ & $\begin{array}{c}0.0317^{*} \\
(0.0145)\end{array}$ & $\begin{array}{l}-0.00118 \\
(0.00414)\end{array}$ & $\begin{array}{l}-0.0115 \\
(0.0119)\end{array}$ \\
\hline year_2000 & $\begin{array}{l}0.353^{* * *} \\
(0.0396)\end{array}$ & $\begin{array}{c}-0.164^{* * *} \\
(0.0412)\end{array}$ & $\begin{array}{c}-0.277^{* * *} \\
(0.0321)\end{array}$ & $\begin{array}{l}0.113^{* * *} \\
(0.0251)\end{array}$ & $\begin{array}{c}0.630^{* * *} \\
(0.0324)\end{array}$ \\
\hline
\end{tabular}




\begin{tabular}{lccccc}
\hline & LOW FICO & MED FICO & HIGH FICO & MED-HIGH & LOW-HIGH \\
\hline year_2001 & $0.647^{* * *}$ & -0.0663 & $-0.209^{* * *}$ & $0.142^{* * *}$ & $0.855^{* * *}$ \\
& $(0.0400)$ & $(0.0396)$ & $(0.0329)$ & $(0.0263)$ & $(0.0396)$ \\
year_2002 & $0.855^{* * *}$ & $0.117^{* *}$ & -0.0294 & $0.146^{* * *}$ & $0.885^{* * *}$ \\
& $(0.0389)$ & $(0.0372)$ & $(0.0346)$ & $(0.0271)$ & $(0.0395)$ \\
year_2003 & $0.516^{* * *}$ & -0.0307 & $-0.190^{* * *}$ & $0.159^{* * *}$ & $0.706^{* * *}$ \\
& $(0.0374)$ & $(0.0360)$ & $(0.0326)$ & $(0.0269)$ & $(0.0359)$ \\
year_2004 & $0.618^{* * *}$ & $0.250^{* * *}$ & $0.0737^{* *}$ & $0.176^{* * *}$ & $0.545^{* * *}$ \\
& $(0.0327)$ & $(0.0331)$ & $(0.0284)$ & $(0.0274)$ & $(0.0331)$ \\
year_2005 & $0.468^{* * *}$ & $0.162^{* * *}$ & -0.00352 & $0.166^{* * *}$ & $0.472^{* * *}$ \\
& $(0.0251)$ & $(0.0281)$ & $(0.0242)$ & $(0.0191)$ & $(0.0232)$ \\
year_2006 & $0.370^{* * *}$ & 0.0383 & -0.0337 & $0.0720^{* * *}$ & $0.404^{* * *}$ \\
& $(0.0200)$ & $(0.0214)$ & $(0.0193)$ & $(0.0166)$ & $(0.0209)$ \\
Constant & $-10.01^{* * *}$ & $-14.09^{* * *}$ & $-10.40^{* * *}$ & & \\
\hline Observations & $(0.658)$ & $(0.737)$ & $(0.649)$ & & \\
\hline
\end{tabular}

Standard errors in parentheses

${ }^{*} p<0.05, \cdots p<0.01, \cdots p<0.001$ 
Table 5b. Mortgage Choice for Sample Excluding AZ, CA, FL, HI, MD, NV \& CA by FICO Option ARM vs. FRM Choice.

Robust Standard Errors in Parentheses; *, **, and *** denote significance at 10, 5, and 1 percent levels, respectively.

\begin{tabular}{|c|c|c|c|c|c|}
\hline & LOW FICO & MED FICO & HIGH FICO & MED-HIGH & LOW-HIGH \\
\hline \multicolumn{6}{|l|}{ Option_ARM } \\
\hline ARM Margin & $\begin{array}{c}-0.214^{* *} \\
(0.0759)\end{array}$ & $\begin{array}{c}-0.344^{* * *} \\
(0.0469)\end{array}$ & $\begin{array}{c}-0.277^{* * *} \\
(0.0607)\end{array}$ & $\begin{array}{c}-0.0672 \\
(0.0636)\end{array}$ & $\begin{array}{c}0.0631 \\
(0.0910)\end{array}$ \\
\hline ARM Margin*HPI & $\begin{array}{c}0.794 \\
(0.512)\end{array}$ & $\begin{array}{c}1.348^{* * *} \\
(0.345)\end{array}$ & $\begin{array}{c}1.181^{* * *} \\
(0.350)\end{array}$ & $\begin{array}{c}0.166 \\
(0.387)\end{array}$ & $\begin{array}{l}-0.387 \\
(0.569)\end{array}$ \\
\hline FRM Margin & $\begin{array}{c}1.173^{* * *} \\
(0.105)\end{array}$ & $\begin{array}{c}0.621^{* * *} \\
(0.0839)\end{array}$ & $\begin{array}{c}0.577^{* * *} \\
(0.117)\end{array}$ & $\begin{array}{l}0.0438 \\
(0.112)\end{array}$ & $\begin{array}{c}0.596^{* * *} \\
(0.141)\end{array}$ \\
\hline FRM Margin*HPI & $\begin{array}{c}-3.087^{* * *} \\
(0.671)\end{array}$ & $\begin{array}{c}-2.075^{* * *} \\
(0.545)\end{array}$ & $\begin{array}{c}-2.256^{* * *} \\
(0.550)\end{array}$ & $\begin{array}{c}0.181 \\
(0.574)\end{array}$ & $\begin{array}{l}-0.831 \\
(0.794)\end{array}$ \\
\hline Term Premium & $\begin{array}{l}0.541^{* * *} \\
(0.0346)\end{array}$ & $\begin{array}{c}0.433^{* * *} \\
(0.0321)\end{array}$ & $\begin{array}{l}0.446^{* * *} \\
(0.0448)\end{array}$ & $\begin{array}{l}-0.0135 \\
(0.0408)\end{array}$ & $\begin{array}{c}0.0941 \\
(0.0538)\end{array}$ \\
\hline Term Premium *HPI & $\begin{array}{l}-0.387 \\
(0.240)\end{array}$ & $\begin{array}{l}-0.307 \\
(0.228)\end{array}$ & $\begin{array}{l}-0.354 \\
(0.244)\end{array}$ & $\begin{array}{l}0.0473 \\
(0.223)\end{array}$ & $\begin{array}{l}-0.0331 \\
(0.327)\end{array}$ \\
\hline Term Str*LTV_Low & $\begin{array}{c}0.185^{* * *} \\
(0.0490)\end{array}$ & $\begin{array}{c}0.186^{* * *} \\
(0.0318)\end{array}$ & $\begin{array}{c}0.208^{* * *} \\
(0.0435)\end{array}$ & $\begin{array}{l}-0.0221 \\
(0.0437)\end{array}$ & $\begin{array}{l}-0.0231 \\
(0.0657)\end{array}$ \\
\hline Term Str*LTV_Low*HPI & $\begin{array}{c}-1.094^{* * *} \\
(0.324)\end{array}$ & $\begin{array}{c}-0.890^{* * *} \\
(0.213)\end{array}$ & $\begin{array}{c}-0.672^{* *} \\
(0.222)\end{array}$ & $\begin{array}{l}-0.218 \\
(0.242)\end{array}$ & $\begin{array}{l}-0.422 \\
(0.384)\end{array}$ \\
\hline Term Str*LTV_High & $\begin{array}{c}0.230^{* * *} \\
(0.0586)\end{array}$ & $\begin{array}{c}0.279^{* * *} \\
(0.0368)\end{array}$ & $\begin{array}{c}0.289^{* * *} \\
(0.0463)\end{array}$ & $\begin{array}{c}-0.00925 \\
(0.0471)\end{array}$ & $\begin{array}{l}-0.0587 \\
(0.0723)\end{array}$ \\
\hline Term Str*LTV_High*HPI & $\begin{array}{l}-0.828^{*} \\
(0.360)\end{array}$ & $\begin{array}{c}-0.982^{* * *} \\
(0.250)\end{array}$ & $\begin{array}{c}-0.871^{* * *} \\
(0.247)\end{array}$ & $\begin{array}{l}-0.111 \\
(0.264)\end{array}$ & $\begin{array}{l}0.0432 \\
(0.413)\end{array}$ \\
\hline RVol*LTV_Low & $\begin{array}{c}-0.00223^{*} \\
(0.00113)\end{array}$ & $\begin{array}{l}0.00240^{* *} \\
(0.000778)\end{array}$ & $\begin{array}{c}0.00191^{*} \\
(0.000831)\end{array}$ & $\begin{array}{c}0.000488 \\
(0.000857)\end{array}$ & $\begin{array}{c}-0.00414^{* * *} \\
(0.00124)\end{array}$ \\
\hline RVol*LTV_Low*HPI & $\begin{array}{c}0.0102 \\
(0.00779)\end{array}$ & $\begin{array}{l}-0.00519 \\
(0.00461)\end{array}$ & $\begin{array}{c}-0.00858 \\
(0.00458)\end{array}$ & $\begin{array}{c}0.00339 \\
(0.00518)\end{array}$ & $\begin{array}{c}0.0188^{*} \\
(0.00814)\end{array}$ \\
\hline
\end{tabular}




\begin{tabular}{|c|c|c|c|c|c|}
\hline & LOW FICO & MED FICO & HIGH FICO & MED-HIGH & LOW-HIGH \\
\hline RVol*LTV_High & $\begin{array}{c}-0.00938^{* * *} \\
(0.000960)\end{array}$ & $\begin{array}{c}-0.00268^{* * *} \\
(0.000726)\end{array}$ & $\begin{array}{l}-0.00184^{*} \\
(0.000804)\end{array}$ & $\begin{array}{l}-0.000845 \\
(0.000910)\end{array}$ & $\begin{array}{c}-0.00754^{* * *} \\
(0.00116)\end{array}$ \\
\hline RVol*LTV_High*HPI & $\begin{array}{c}0.0110 \\
(0.00761)\end{array}$ & $\begin{array}{l}-0.00779 \\
(0.00470)\end{array}$ & $\begin{array}{l}-0.00938^{*} \\
(0.00452)\end{array}$ & $\begin{array}{c}0.00159 \\
(0.00534)\end{array}$ & $\begin{array}{c}0.0204^{*} \\
(0.00816)\end{array}$ \\
\hline LTV & $\begin{array}{c}-0.00673^{* * *} \\
(0.00118)\end{array}$ & $\begin{array}{c}0.00638^{* * *} \\
(0.000683)\end{array}$ & $\begin{array}{l}0.0122^{* * *} \\
(0.000551)\end{array}$ & $\begin{array}{c}-0.00585^{* * *} \\
(0.000570)\end{array}$ & $\begin{array}{c}-0.0190^{* * *} \\
(0.00129)\end{array}$ \\
\hline $\mathrm{LTV}=0.8$ & $\begin{array}{l}1.062^{* * *} \\
(0.0409)\end{array}$ & $\begin{array}{c}0.604^{* * *} \\
(0.0203)\end{array}$ & $\begin{array}{c}0.410^{* * *} \\
(0.0195)\end{array}$ & $\begin{array}{c}0.193^{* * *} \\
(0.0199)\end{array}$ & $\begin{array}{c}0.652^{* * *} \\
(0.0409)\end{array}$ \\
\hline Conforming & $\begin{array}{c}-1.398^{* * *} \\
(0.0331)\end{array}$ & $\begin{array}{c}-1.144^{* * *} \\
(0.0273)\end{array}$ & $\begin{array}{c}-1.019^{* * *} \\
(0.0280)\end{array}$ & $\begin{array}{c}-0.125^{* * *} \\
(0.0177)\end{array}$ & $\begin{array}{c}-0.379^{* * *} \\
(0.0337)\end{array}$ \\
\hline Documented & $\begin{array}{c}0.0745^{* *} \\
(0.0229)\end{array}$ & $\begin{array}{l}0.130^{* * *} \\
(0.0170)\end{array}$ & $\begin{array}{c}0.265^{* * *} \\
(0.0170)\end{array}$ & $\begin{array}{c}-0.134^{* * *} \\
(0.0105)\end{array}$ & $\begin{array}{c}-0.190^{* * *} \\
(0.0236)\end{array}$ \\
\hline FICO & $\begin{array}{c}-0.00279^{* * *} \\
(0.000338)\end{array}$ & $\begin{array}{c}-0.00234^{* * *} \\
(0.000143)\end{array}$ & $\begin{array}{c}-0.00654^{* * *} \\
(0.000280)\end{array}$ & $\begin{array}{l}0.00420^{* * *} \\
(0.000297)\end{array}$ & $\begin{array}{l}0.00375^{* * *} \\
(0.000504)\end{array}$ \\
\hline Subprime & $\begin{array}{l}1.852^{* * *} \\
(0.0273)\end{array}$ & $\begin{array}{l}1.626^{* * *} \\
(0.0376)\end{array}$ & $\begin{array}{l}1.146^{* * *} \\
(0.0603)\end{array}$ & $\begin{array}{c}0.480^{* * *} \\
(0.0370)\end{array}$ & $\begin{array}{l}0.706^{* * *} \\
(0.0483)\end{array}$ \\
\hline HPI Appr.(Two-year Log Difference) & $\begin{array}{c}4.182^{* * *} \\
(0.925)\end{array}$ & $\begin{array}{c}4.141^{* * *} \\
(0.958)\end{array}$ & $\begin{array}{c}5.118^{* * *} \\
(0.857)\end{array}$ & $\begin{array}{l}-0.977 \\
(0.827)\end{array}$ & $\begin{array}{l}-0.936 \\
(1.082)\end{array}$ \\
\hline HPI Vol & $\begin{array}{c}-17.92^{* * *} \\
(4.484)\end{array}$ & $\begin{array}{c}-12.04^{* *} \\
(4.297)\end{array}$ & $\begin{array}{c}2.377 \\
(4.664)\end{array}$ & $\begin{array}{c}-14.41^{* * *} \\
(2.063)\end{array}$ & $\begin{array}{c}-20.30^{* * *} \\
(4.439)\end{array}$ \\
\hline Log Real Inc. & $\begin{array}{l}0.877^{* * *} \\
(0.0742)\end{array}$ & $\begin{array}{l}0.961^{* * *} \\
(0.0691)\end{array}$ & $\begin{array}{l}0.866^{* * *} \\
(0.0678)\end{array}$ & $\begin{array}{c}0.0951^{* * *} \\
(0.0246)\end{array}$ & $\begin{array}{c}0.0109 \\
(0.0598)\end{array}$ \\
\hline UR(County) & $\begin{array}{c}0.133^{* * *} \\
(0.0161)\end{array}$ & $\begin{array}{l}0.112^{* * *} \\
(0.0177)\end{array}$ & $\begin{array}{c}0.0803^{* * *} \\
(0.0180)\end{array}$ & $\begin{array}{c}0.0320^{* * *} \\
(0.00863)\end{array}$ & $\begin{array}{c}0.0523^{* * *} \\
(0.0151)\end{array}$ \\
\hline year_2000 & $\begin{array}{l}1.021^{* * *} \\
(0.0462)\end{array}$ & $\begin{array}{l}-0.0146 \\
(0.0467)\end{array}$ & $\begin{array}{l}-0.102^{*} \\
(0.0454)\end{array}$ & $\begin{array}{l}0.0871^{*} \\
(0.0363)\end{array}$ & $\begin{array}{l}1.122^{* * *} \\
(0.0521)\end{array}$ \\
\hline
\end{tabular}




\begin{tabular}{lccccc}
\hline & LOW FICO & MED FICO & HIGH FICO & MED-HIGH & LOW-HIGH \\
\hline year_2001 & $1.359^{* * *}$ & $-0.132^{* *}$ & $-0.392^{* * *}$ & $0.259^{* * *}$ & $1.751^{* * *}$ \\
& $(0.0552)$ & $(0.0504)$ & $(0.0522)$ & $(0.0435)$ & $(0.0576)$ \\
year_2002 & $1.538^{* * *}$ & $0.189^{* * *}$ & -0.0276 & $0.217^{* * *}$ & $1.565^{* * *}$ \\
& $(0.0502)$ & $(0.0403)$ & $(0.0462)$ & $(0.0448)$ & $(0.0627)$ \\
year_2003 & $1.025^{* * *}$ & -0.00953 & $-0.199^{* * *}$ & $0.189^{* * *}$ & $1.224^{* * *}$ \\
& $(0.0415)$ & $(0.0366)$ & $(0.0459)$ & $(0.0445)$ & $(0.0586)$ \\
year_2004 & $0.960^{* * *}$ & $0.166^{* * *}$ & 0.0397 & $0.126^{* *}$ & $0.920^{* * *}$ \\
& $(0.0404)$ & $(0.0319)$ & $(0.0370)$ & $(0.0388)$ & $(0.0529)$ \\
year_2005 & $0.950^{* * *}$ & $0.234^{* * *}$ & $0.123^{* * *}$ & $0.110^{* * *}$ & $0.826^{* * *}$ \\
& $(0.0327)$ & $(0.0252)$ & $(0.0262)$ & $(0.0262)$ & $(0.0374)$ \\
year_2006 & $0.577^{* * *}$ & $0.0543^{* *}$ & $0.0488^{*}$ & 0.00546 & $0.528^{* * *}$ \\
& $(0.0292)$ & $(0.0202)$ & $(0.0200)$ & $(0.0208)$ & $(0.0333)$ \\
Constant & $-11.59^{* * *}$ & $-12.53^{* * *}$ & $-8.755^{* * *}$ & & $(0.780)$ \\
\hline Observations & $(0.939)$ & $(0.809)$ & &
\end{tabular}


Table 6a. Mortgage Choice for AZ, CA, FL, HI, MD, NV \& CA by FICO Non-Option ARM vs. FRM Choice.

Robust Standard Errors in Parentheses; *, **, and *** denote significance at 10, 5, and 1 percent levels, respectively.

\begin{tabular}{|c|c|c|c|c|c|}
\hline & LOW FICO & MED FICO & HIGH FICO & MED-HIGH & LOW-HIGH \\
\hline \multicolumn{6}{|l|}{ ARM } \\
\hline ARM Margin & $\begin{array}{c}-1.157^{* * *} \\
(0.131)\end{array}$ & $\begin{array}{c}-0.619^{* * *} \\
(0.0733)\end{array}$ & $\begin{array}{c}-0.507^{* * *} \\
(0.0673)\end{array}$ & $\begin{array}{l}-0.112^{*} \\
(0.0525)\end{array}$ & $\begin{array}{c}-0.650^{* * *} \\
(0.133)\end{array}$ \\
\hline ARM Margin*HPI & $\begin{array}{c}3.707^{* * *} \\
(0.559)\end{array}$ & $\begin{array}{c}1.811^{* * *} \\
(0.327)\end{array}$ & $\begin{array}{c}1.685^{* * *} \\
(0.203)\end{array}$ & $\begin{array}{c}0.126 \\
(0.264)\end{array}$ & $\begin{array}{c}2.022^{* * *} \\
(0.539)\end{array}$ \\
\hline FRM Margin & $\begin{array}{c}1.053^{* * *} \\
(0.148)\end{array}$ & $\begin{array}{c}1.359^{* * *} \\
(0.109)\end{array}$ & $\begin{array}{c}1.181^{* * *} \\
(0.114)\end{array}$ & $\begin{array}{c}0.178^{*} \\
(0.0906)\end{array}$ & $\begin{array}{l}-0.128 \\
(0.153)\end{array}$ \\
\hline FRM Margin*HPI & $\begin{array}{l}-0.953 \\
(0.558)\end{array}$ & $\begin{array}{c}-2.602^{* * *} \\
(0.446)\end{array}$ & $\begin{array}{c}-2.130^{* * *} \\
(0.411)\end{array}$ & $\begin{array}{l}-0.472 \\
(0.386)\end{array}$ & $\begin{array}{l}1.176^{*} \\
(0.600)\end{array}$ \\
\hline Term Premium & $\begin{array}{c}0.936^{* * *} \\
(0.0643)\end{array}$ & $\begin{array}{l}0.808^{* * *} \\
(0.0614)\end{array}$ & $\begin{array}{l}0.701^{* * *} \\
(0.0503)\end{array}$ & $\begin{array}{l}0.107^{* * *} \\
(0.0313)\end{array}$ & $\begin{array}{l}0.235^{* * *} \\
(0.0556)\end{array}$ \\
\hline Term Premium *HPI & $\begin{array}{c}-0.819^{* *} \\
(0.289)\end{array}$ & $\begin{array}{l}-0.422 \\
(0.269)\end{array}$ & $\begin{array}{l}-0.311 \\
(0.218)\end{array}$ & $\begin{array}{l}-0.111 \\
(0.141)\end{array}$ & $\begin{array}{l}-0.508^{*} \\
(0.245)\end{array}$ \\
\hline Term Str*LTV_Low & $\begin{array}{l}0.603^{* * *} \\
(0.0962)\end{array}$ & $\begin{array}{l}0.339^{* * *} \\
(0.0733)\end{array}$ & $\begin{array}{l}0.347^{* * *} \\
(0.0567)\end{array}$ & $\begin{array}{c}-0.00779 \\
(0.0423)\end{array}$ & $\begin{array}{l}0.256^{* *} \\
(0.0852)\end{array}$ \\
\hline Term Str*LTV_Low*HPI & $\begin{array}{c}-1.907^{* * *} \\
(0.399)\end{array}$ & $\begin{array}{l}-0.839^{*} \\
(0.329)\end{array}$ & $\begin{array}{c}-0.828^{* * *} \\
(0.221)\end{array}$ & $\begin{array}{l}-0.0113 \\
(0.189)\end{array}$ & $\begin{array}{c}-1.079^{* * *} \\
(0.322)\end{array}$ \\
\hline Term Str*LTV_High & $\begin{array}{c}0.777^{* * *} \\
(0.0981)\end{array}$ & $\begin{array}{c}0.473^{* * *} \\
(0.0749)\end{array}$ & $\begin{array}{l}0.401^{* * *} \\
(0.0603)\end{array}$ & $\begin{array}{c}0.0721 \\
(0.0397)\end{array}$ & $\begin{array}{c}0.376^{* * *} \\
(0.0863)\end{array}$ \\
\hline Term Str*LTV_High*HPI & $\begin{array}{c}-2.086^{* * *} \\
(0.426)\end{array}$ & $\begin{array}{c}-1.011^{* *} \\
(0.339)\end{array}$ & $\begin{array}{c}-0.945^{* * *} \\
(0.245)\end{array}$ & $\begin{array}{l}-0.0668 \\
(0.180)\end{array}$ & $\begin{array}{c}-1.141^{* * *} \\
(0.346)\end{array}$ \\
\hline RVol*LTV_Low & $\begin{array}{l}0.0111^{* * *} \\
(0.00122)\end{array}$ & $\begin{array}{c}0.00618^{* * *} \\
(0.000783)\end{array}$ & $\begin{array}{c}0.00183^{*} \\
(0.000828)\end{array}$ & $\begin{array}{c}0.00435^{* * *} \\
(0.000663)\end{array}$ & $\begin{array}{c}0.00928^{* * *} \\
(0.00116)\end{array}$ \\
\hline RVol*LTV_Low*HPI & $\begin{array}{c}-0.0402^{* * *} \\
(0.00500)\end{array}$ & $\begin{array}{c}-0.0253^{* * *} \\
(0.00266)\end{array}$ & $\begin{array}{c}-0.0138^{* * *} \\
(0.00270)\end{array}$ & $\begin{array}{c}-0.0115^{* * *} \\
(0.00233)\end{array}$ & $\begin{array}{c}-0.0264^{* * *} \\
(0.00530)\end{array}$ \\
\hline
\end{tabular}




\begin{tabular}{|c|c|c|c|c|c|}
\hline & LOW FICO & MED FICO & HIGH FICO & MED-HIGH & LOW-HIGH \\
\hline RVol*LTV_High & $\begin{array}{l}0.00251^{*} \\
(0.00115)\end{array}$ & $\begin{array}{l}-0.00235^{* *} \\
(0.000717)\end{array}$ & $\begin{array}{c}-0.00334^{* * *} \\
(0.000787)\end{array}$ & $\begin{array}{c}0.000988 \\
(0.000673)\end{array}$ & $\begin{array}{c}0.00585^{* * *} \\
(0.00112)\end{array}$ \\
\hline RVol*LTV_High*HPI & $\begin{array}{c}-0.0337^{* * *} \\
(0.00487)\end{array}$ & $\begin{array}{c}-0.0236^{* * *} \\
(0.00307)\end{array}$ & $\begin{array}{c}-0.00990^{* * *} \\
(0.00276)\end{array}$ & $\begin{array}{c}-0.0137^{* * *} \\
(0.00246)\end{array}$ & $\begin{array}{c}-0.0238^{* * *} \\
(0.00538)\end{array}$ \\
\hline LTV & $\begin{array}{l}0.0102^{* * *} \\
(0.00118)\end{array}$ & $\begin{array}{c}0.0209^{* * *} \\
(0.000831)\end{array}$ & $\begin{array}{c}0.0189^{* * *} \\
(0.000637)\end{array}$ & $\begin{array}{c}0.00202^{* * *} \\
(0.000531)\end{array}$ & $\begin{array}{c}-0.00870^{* * *} \\
(0.00106)\end{array}$ \\
\hline $\mathrm{LTV}=0.8$ & $\begin{array}{l}1.075^{* * *} \\
(0.0324)\end{array}$ & $\begin{array}{c}0.908^{* * *} \\
(0.0253)\end{array}$ & $\begin{array}{l}0.484^{* * *} \\
(0.0355)\end{array}$ & $\begin{array}{l}0.424^{* * *} \\
(0.0186)\end{array}$ & $\begin{array}{l}0.591^{* * *} \\
(0.0450)\end{array}$ \\
\hline Conforming & $\begin{array}{c}-0.815^{* * *} \\
(0.0364)\end{array}$ & $\begin{array}{c}-0.779^{* * *} \\
(0.0357)\end{array}$ & $\begin{array}{c}-0.922^{* * *} \\
(0.0346)\end{array}$ & $\begin{array}{l}0.143^{* * *} \\
(0.0108)\end{array}$ & $\begin{array}{l}0.107^{* * *} \\
(0.0201)\end{array}$ \\
\hline Documented & $\begin{array}{c}-0.291^{\text {*** }} \\
(0.0135)\end{array}$ & $\begin{array}{c}-0.145^{* * *} \\
(0.0128)\end{array}$ & $\begin{array}{c}-0.101^{* * *} \\
(0.0227)\end{array}$ & $\begin{array}{c}-0.0438^{* *} \\
(0.0161)\end{array}$ & $\begin{array}{c}-0.189^{* * *} \\
(0.0228)\end{array}$ \\
\hline FICO & $\begin{array}{l}0.000488^{*} \\
(0.000191)\end{array}$ & $\begin{array}{c}-0.000281^{*} \\
(0.000140)\end{array}$ & $\begin{array}{c}-0.00564^{* * *} \\
(0.000234)\end{array}$ & $\begin{array}{l}0.00536^{* * *} \\
(0.000227)\end{array}$ & $\begin{array}{c}0.00613^{* * *} \\
(0.000349)\end{array}$ \\
\hline Subprime & $\begin{array}{l}1.646^{* * *} \\
(0.0312)\end{array}$ & $\begin{array}{l}1.238^{* * *} \\
(0.0223)\end{array}$ & $\begin{array}{l}1.098^{* * *} \\
(0.0365)\end{array}$ & $\begin{array}{l}0.140^{* * *} \\
(0.0274)\end{array}$ & $\begin{array}{l}0.548^{* * *} \\
(0.0458)\end{array}$ \\
\hline HPI Appr.(Two-year Log Difference) & $\begin{array}{c}1.375 \\
(0.786)\end{array}$ & $\begin{array}{c}4.939^{* * *} \\
(0.740)\end{array}$ & $\begin{array}{c}2.889^{* * *} \\
(0.659)\end{array}$ & $\begin{array}{c}2.051^{* * *} \\
(0.464)\end{array}$ & $\begin{array}{l}-1.513 \\
(0.873)\end{array}$ \\
\hline HPI Vol & $\begin{array}{l}-12.32^{*} \\
(5.574)\end{array}$ & $\begin{array}{c}4.481 \\
(6.041)\end{array}$ & $\begin{array}{l}10.78^{*} \\
(5.001)\end{array}$ & $\begin{array}{c}-6.295^{* *} \\
(2.034)\end{array}$ & $\begin{array}{c}-23.09^{* * *} \\
(3.254)\end{array}$ \\
\hline Log Real Inc. & $\begin{array}{c}0.642^{* * *} \\
(0.111)\end{array}$ & $\begin{array}{c}0.661^{* * *} \\
(0.116)\end{array}$ & $\begin{array}{c}0.610^{* * *} \\
(0.107)\end{array}$ & $\begin{array}{c}0.0508 \\
(0.0389)\end{array}$ & $\begin{array}{c}0.0318 \\
(0.0791)\end{array}$ \\
\hline UR(County) & $\begin{array}{c}-0.0503^{* *} \\
(0.0184)\end{array}$ & $\begin{array}{c}-0.0544^{* *} \\
(0.0200)\end{array}$ & $\begin{array}{c}-0.0438^{*} \\
(0.0194)\end{array}$ & $\begin{array}{c}-0.0106 \\
(0.00740)\end{array}$ & $\begin{array}{l}-0.00645 \\
(0.0147)\end{array}$ \\
\hline year_2000 & $\begin{array}{c}-0.553^{* * *} \\
(0.0725)\end{array}$ & $\begin{array}{c}-0.860^{* * *} \\
(0.0648)\end{array}$ & $\begin{array}{c}-0.803^{* * *} \\
(0.0454)\end{array}$ & $\begin{array}{l}-0.0567 \\
(0.0452)\end{array}$ & $\begin{array}{l}0.251^{* * *} \\
(0.0569)\end{array}$ \\
\hline
\end{tabular}




\begin{tabular}{lccccc}
\hline & LOW FICO & MED FICO & HIGH FICO & MED-HIGH & LOW-HIGH \\
\hline year_2001 & $-0.478^{* * *}$ & $-0.602^{* * *}$ & $-0.555^{* * *}$ & -0.0469 & 0.0772 \\
& $(0.0828)$ & $(0.0602)$ & $(0.0578)$ & $(0.0391)$ & $(0.0676)$ \\
year_2002 & -0.123 & $-0.170^{* *}$ & $-0.175^{* *}$ & 0.00521 & 0.0525 \\
& $(0.0811)$ & $(0.0609)$ & $(0.0641)$ & $(0.0426)$ & $(0.0791)$ \\
year_2003 & $-0.210^{* *}$ & $-0.213^{* * *}$ & $-0.222^{* * *}$ & 0.00860 & 0.0119 \\
& $(0.0763)$ & $(0.0549)$ & $(0.0621)$ & $(0.0418)$ & $(0.0752)$ \\
year_2004 & 0.00269 & 0.00613 & -0.0120 & 0.0182 & 0.0147 \\
& $(0.0737)$ & $(0.0541)$ & $(0.0539)$ & $(0.0384)$ & $(0.0707)$ \\
year_2005 & 0.0710 & 0.0719 & 0.0779 & -0.00599 & -0.00686 \\
& $(0.0480)$ & $(0.0448)$ & $(0.0491)$ & $(0.0297)$ & $(0.0517)$ \\
year_2006 & -0.0263 & -0.0157 & 0.0124 & -0.0281 & -0.0387 \\
& $(0.0510)$ & $(0.0369)$ & $(0.0330)$ & $(0.0281)$ & $(0.0525)$ \\
Constant & $-9.938^{* * *}$ & $-11.14^{* * *}$ & $-5.668^{* * *}$ & & $(1.228)$ \\
\hline Observations & $(1.352)$ & $(1.394)$ & & \\
\hline
\end{tabular}

Standard errors in parentheses

${ }^{*} p<0.05, \cdots p<0.01, \cdots p<0.001$ 
Table 6b. Mortgage Choice for AZ, CA, FL, HI, MD, NV \& CA by FICO.

Option ARM vs. FRM Choice. Robust Standard Errors in Parentheses; *, **, and *** denote significance at 10,5 , and 1 percent levels, respectively.

\begin{tabular}{|c|c|c|c|c|c|}
\hline & LOW FICO & MED FICO & HIGH FICO & MED-HIGH & LOW-HIGH \\
\hline \multicolumn{6}{|l|}{ Option_ARM } \\
\hline ARM Margin & $\begin{array}{c}-0.775^{* * *} \\
(0.166)\end{array}$ & $\begin{array}{c}-0.161^{* *} \\
(0.0601)\end{array}$ & $\begin{array}{l}-0.278^{* *} \\
(0.0921)\end{array}$ & $\begin{array}{c}0.117 \\
(0.0920)\end{array}$ & $\begin{array}{c}-0.497^{* *} \\
(0.183)\end{array}$ \\
\hline ARM Margin*HPI & $\begin{array}{c}3.049^{* * *} \\
(0.541)\end{array}$ & $\begin{array}{c}1.043^{* * *} \\
(0.218)\end{array}$ & $\begin{array}{c}1.118^{* * *} \\
(0.290)\end{array}$ & $\begin{array}{l}-0.0749 \\
(0.316)\end{array}$ & $\begin{array}{c}1.931^{* * *} \\
(0.540)\end{array}$ \\
\hline FRM Margin & $\begin{array}{c}1.643^{* * *} \\
(0.271)\end{array}$ & $\begin{array}{c}1.380^{* * *} \\
(0.133)\end{array}$ & $\begin{array}{c}1.176^{* * *} \\
(0.141)\end{array}$ & $\begin{array}{c}0.203 \\
(0.111)\end{array}$ & $\begin{array}{l}0.467^{*} \\
(0.221)\end{array}$ \\
\hline FRM Margin*HPI & $\begin{array}{c}-4.140^{* * *} \\
(0.834)\end{array}$ & $\begin{array}{c}-3.455^{* * *} \\
(0.446)\end{array}$ & $\begin{array}{c}-2.721^{* * *} \\
(0.479)\end{array}$ & $\begin{array}{l}-0.734 \\
(0.394)\end{array}$ & $\begin{array}{r}-1.420^{*} \\
(0.635)\end{array}$ \\
\hline Term Premium & $\begin{array}{c}0.687^{* * *} \\
(0.0864)\end{array}$ & $\begin{array}{l}0.531^{* * *} \\
(0.0613)\end{array}$ & $\begin{array}{l}0.515^{* * *} \\
(0.0543)\end{array}$ & $\begin{array}{c}0.0153 \\
(0.0477)\end{array}$ & $\begin{array}{c}0.171^{*} \\
(0.0754)\end{array}$ \\
\hline Term Premium *HPI & $\begin{array}{c}-1.275^{* * *} \\
(0.312)\end{array}$ & $\begin{array}{l}-0.571^{*} \\
(0.243)\end{array}$ & $\begin{array}{l}-0.351 \\
(0.212)\end{array}$ & $\begin{array}{l}-0.220 \\
(0.181)\end{array}$ & $\begin{array}{c}-0.924^{* * *} \\
(0.257)\end{array}$ \\
\hline Term Str*LTV_Low & $\begin{array}{c}0.480^{* * *} \\
(0.118)\end{array}$ & $\begin{array}{l}-0.0335 \\
(0.0584)\end{array}$ & $\begin{array}{c}0.0973 \\
(0.0722)\end{array}$ & $\begin{array}{l}-0.131^{*} \\
(0.0565)\end{array}$ & $\begin{array}{c}0.383^{* *} \\
(0.121)\end{array}$ \\
\hline Term Str*LTV_Low*HPI & $\begin{array}{c}-2.267^{* * *} \\
(0.413)\end{array}$ & $\begin{array}{c}-0.595^{*} \\
(0.235)\end{array}$ & $\begin{array}{c}-0.584^{*} \\
(0.237)\end{array}$ & $\begin{array}{l}-0.0108 \\
(0.201)\end{array}$ & $\begin{array}{c}-1.683^{* * *} \\
(0.390)\end{array}$ \\
\hline Term Str*LTV_High & $\begin{array}{c}0.642^{* * *} \\
(0.113)\end{array}$ & $\begin{array}{c}0.108 \\
(0.0673)\end{array}$ & $\begin{array}{l}0.194^{* *} \\
(0.0741)\end{array}$ & $\begin{array}{l}-0.0857 \\
(0.0547)\end{array}$ & $\begin{array}{c}0.448^{* * *} \\
(0.112)\end{array}$ \\
\hline Term Str*LTV_High*HPI & $\begin{array}{c}-2.386^{* * *} \\
(0.392)\end{array}$ & $\begin{array}{c}-0.832^{* *} \\
(0.259)\end{array}$ & $\begin{array}{c}-0.790^{* *} \\
(0.244)\end{array}$ & $\begin{array}{l}-0.0421 \\
(0.207)\end{array}$ & $\begin{array}{c}-1.596^{* * *} \\
(0.348)\end{array}$ \\
\hline RVol*LTV_Low & $\begin{array}{c}0.00540^{* * *} \\
(0.00135)\end{array}$ & $\begin{array}{l}0.00450^{* * *} \\
(0.000888)\end{array}$ & $\begin{array}{l}0.00230^{*} \\
(0.00104)\end{array}$ & $\begin{array}{l}0.00220^{*} \\
(0.00102)\end{array}$ & $\begin{array}{l}0.00311^{* *} \\
(0.00105)\end{array}$ \\
\hline RVol*LTV_Low*HPI & $\begin{array}{l}-0.00712 \\
(0.00524)\end{array}$ & $\begin{array}{c}-0.0167^{* * *} \\
(0.00330)\end{array}$ & $\begin{array}{l}-0.0108^{* *} \\
(0.00374)\end{array}$ & $\begin{array}{l}-0.00583 \\
(0.00433)\end{array}$ & $\begin{array}{c}0.00371 \\
(0.00486)\end{array}$ \\
\hline
\end{tabular}




\begin{tabular}{|c|c|c|c|c|c|}
\hline & LOW FICO & MED FICO & HIGH FICO & MED-HIGH & LOW-HIGH \\
\hline RVol*LTV_High & $\begin{array}{c}-0.00768^{* * *} \\
(0.00150)\end{array}$ & $\begin{array}{c}-0.00486^{* * *} \\
(0.00100)\end{array}$ & $\begin{array}{c}-0.00504^{* * *} \\
(0.000997)\end{array}$ & $\begin{array}{l}0.000184 \\
(0.00102)\end{array}$ & $\begin{array}{l}-0.00263^{*} \\
(0.00117)\end{array}$ \\
\hline RVol*LTV_High*HPI & $\begin{array}{c}0.00160 \\
(0.00552)\end{array}$ & $\begin{array}{c}-0.0122^{* * *} \\
(0.00343)\end{array}$ & $\begin{array}{l}-0.00540 \\
(0.00378)\end{array}$ & $\begin{array}{l}-0.00684 \\
(0.00376)\end{array}$ & $\begin{array}{c}0.00700 \\
(0.00505)\end{array}$ \\
\hline LTV & $\begin{array}{l}0.00578^{* * *} \\
(0.000925)\end{array}$ & $\begin{array}{l}0.0147^{* * *} \\
(0.000647)\end{array}$ & $\begin{array}{c}0.0185^{* * *} \\
(0.000492)\end{array}$ & $\begin{array}{c}-0.00376^{* * *} \\
(0.000614)\end{array}$ & $\begin{array}{l}-0.0127^{* * *} \\
(0.000892)\end{array}$ \\
\hline $\mathrm{LTV}=0.8$ & $\begin{array}{l}1.375^{* * *} \\
(0.0375)\end{array}$ & $\begin{array}{l}0.852^{* * *} \\
(0.0332)\end{array}$ & $\begin{array}{l}0.586^{* * *} \\
(0.0286)\end{array}$ & $\begin{array}{l}0.266^{* * *} \\
(0.0179)\end{array}$ & $\begin{array}{l}0.789^{* * *} \\
(0.0319)\end{array}$ \\
\hline Conforming & $\begin{array}{c}-1.133^{* * *} \\
(0.0507)\end{array}$ & $\begin{array}{c}-0.965^{* * *} \\
(0.0346)\end{array}$ & $\begin{array}{c}-0.855^{* * *} \\
(0.0282)\end{array}$ & $\begin{array}{c}-0.111^{* * *} \\
(0.0167)\end{array}$ & $\begin{array}{c}-0.279^{* * *} \\
(0.0337)\end{array}$ \\
\hline Documented & $\begin{array}{c}-0.240^{* * *} \\
(0.0256)\end{array}$ & $\begin{array}{c}-0.181^{* * *} \\
(0.0199)\end{array}$ & $\begin{array}{l}-0.0610^{*} \\
(0.0298)\end{array}$ & $\begin{array}{c}-0.120^{* * *} \\
(0.0163)\end{array}$ & $\begin{array}{c}-0.179^{* * *} \\
(0.0389)\end{array}$ \\
\hline $\mathrm{FICO}$ & $\begin{array}{l}0.000598 * \\
(0.000274)\end{array}$ & $\begin{array}{c}-0.00366^{* * *} \\
(0.000318)\end{array}$ & $\begin{array}{c}-0.00781^{* * *} \\
(0.000233)\end{array}$ & $\begin{array}{l}0.00415^{* * *} \\
(0.000369)\end{array}$ & $\begin{array}{c}0.00841^{* * *} \\
(0.000380)\end{array}$ \\
\hline Subprime & $\begin{array}{l}1.357^{* * *} \\
(0.0919)\end{array}$ & $\begin{array}{l}0.937^{* * *} \\
(0.0724)\end{array}$ & $\begin{array}{l}0.532^{* * *} \\
(0.0665)\end{array}$ & $\begin{array}{l}0.405^{* * *} \\
(0.0448)\end{array}$ & $\begin{array}{l}0.825^{* * *} \\
(0.0774)\end{array}$ \\
\hline HPI Appr.(Two-year Log Difference) & $\begin{array}{c}5.059^{* * *} \\
(0.911)\end{array}$ & $\begin{array}{c}7.398^{* * *} \\
(0.794)\end{array}$ & $\begin{array}{c}5.046^{* * *} \\
(0.914)\end{array}$ & $\begin{array}{c}2.352^{* * *} \\
(0.607)\end{array}$ & $\begin{array}{l}0.0127 \\
(0.936)\end{array}$ \\
\hline HPI Vol & $\begin{array}{c}-26.70^{* *} \\
(9.290)\end{array}$ & $\begin{array}{l}-7.769 \\
(8.268)\end{array}$ & $\begin{array}{l}-0.603 \\
(6.918)\end{array}$ & $\begin{array}{c}-7.166^{* *} \\
(2.452)\end{array}$ & $\begin{array}{c}-26.10^{* * *} \\
(5.145)\end{array}$ \\
\hline Log Real Inc. & $\begin{array}{c}1.084^{* * *} \\
(0.146)\end{array}$ & $\begin{array}{c}0.890^{* * *} \\
(0.126)\end{array}$ & $\begin{array}{c}0.717^{* * *} \\
(0.114)\end{array}$ & $\begin{array}{l}0.173^{* * *} \\
(0.0467)\end{array}$ & $\begin{array}{c}0.367^{* * *} \\
(0.106)\end{array}$ \\
\hline UR(County) & $\begin{array}{c}0.0436 \\
(0.0264)\end{array}$ & $\begin{array}{c}0.0143 \\
(0.0225)\end{array}$ & $\begin{array}{l}0.00380 \\
(0.0215)\end{array}$ & $\begin{array}{c}0.0105 \\
(0.00700)\end{array}$ & $\begin{array}{l}0.0398^{*} \\
(0.0164)\end{array}$ \\
\hline year_2000 & $\begin{array}{l}-0.121 \\
(0.112)\end{array}$ & $\begin{array}{c}-0.663^{* * *} \\
(0.112)\end{array}$ & $\begin{array}{c}-0.640^{* * *} \\
(0.0725)\end{array}$ & $\begin{array}{l}-0.0228 \\
(0.0691)\end{array}$ & $\begin{array}{l}0.519^{* * *} \\
(0.0820)\end{array}$ \\
\hline
\end{tabular}




\begin{tabular}{lccccc}
\hline & LOW FICO & MED FICO & HIGH FICO & MED-HIGH & LOW-HIGH \\
\hline year_2001 & -0.0255 & $-0.650^{* * *}$ & $-0.799^{* * *}$ & 0.149 & $0.773^{* * *}$ \\
& $(0.138)$ & $(0.113)$ & $(0.0840)$ & $(0.0790)$ & $(0.108)$ \\
year_2002 & $0.358^{* *}$ & -0.0335 & $-0.244^{* *}$ & $0.211^{* * *}$ & $0.602^{* * *}$ \\
& $(0.121)$ & $(0.109)$ & $(0.0875)$ & $(0.0552)$ & $(0.100)$ \\
year_2003 & $0.264^{*}$ & -0.123 & $-0.247^{* *}$ & $0.124^{*}$ & $0.511^{* * *}$ \\
& $(0.108)$ & $(0.0959)$ & $(0.0765)$ & $(0.0619)$ & $(0.0913)$ \\
year_2004 & $0.325^{* * *}$ & -0.0506 & -0.101 & 0.0505 & $0.426^{* * *}$ \\
& $(0.0907)$ & $(0.0775)$ & $(0.0681)$ & $(0.0509)$ & $(0.0794)$ \\
year_2005 & $0.363^{* * *}$ & 0.133 & 0.0812 & 0.0520 & $0.282^{* * *}$ \\
& $(0.0748)$ & $(0.0758)$ & $(0.0763)$ & $(0.0365)$ & $(0.0734)$ \\
year_2006 & 0.0676 & -0.108 & -0.0308 & $-0.0774^{*}$ & 0.0984 \\
& $(0.0702)$ & $(0.0603)$ & $(0.0571)$ & $(0.0346)$ & $(0.0704)$ \\
Constant & $-16.04^{* * *}$ & $-12.05^{* * *}$ & $-6.603^{* * *}$ & & \\
& $(1.698)$ & $(1.412)$ & $(1.334)$ & & \\
\hline Observations & 656999 & 1745512 & 883506 & & \\
\hline
\end{tabular}

Standard errors in parentheses

${ }^{*} p<0.05, \cdots p<0.01, \cdots p<0.001$ 
Table 7. Summary Statistics by FICO Group in 2005.

\begin{tabular}{|c|c|c|}
\hline & High FICO & Low FICO \\
\hline \multirow[t]{2}{*}{ ARM_share } & 0.270 & 0.376 \\
\hline & $(0.444)$ & $(0.484)$ \\
\hline \multirow[t]{2}{*}{ Option_ARM_share } & 0.0772 & 0.115 \\
\hline & $(0.267)$ & $(0.320)$ \\
\hline \multirow[t]{2}{*}{ ARM Margin (ppt) } & 0.845 & 0.856 \\
\hline & $(0.156)$ & $(0.160)$ \\
\hline \multirow[t]{2}{*}{ FRM Margin (ppt) } & 1.576 & 1.576 \\
\hline & $(0.103)$ & $(0.108)$ \\
\hline \multirow[t]{2}{*}{ Term Premium (ppt) } & 2.348 & 2.360 \\
\hline & $(0.158)$ & $(0.164)$ \\
\hline \multirow[t]{2}{*}{ Term Str*LTV_Low (ppt) } & -1.190 & -0.575 \\
\hline & $(0.829)$ & $(0.830)$ \\
\hline \multirow[t]{2}{*}{ Term Str*LTV_High (ppt) } & -0.522 & -1.129 \\
\hline & $(0.801)$ & $(0.837)$ \\
\hline \multirow[t]{2}{*}{ RVol*LTV_Low (index) } & 54.43 & 26.29 \\
\hline & $(36.41)$ & $(37.19)$ \\
\hline \multirow[t]{2}{*}{ RVol*LTV_High (index) } & 24.16 & 52.48 \\
\hline & $(36.39)$ & $(37.40)$ \\
\hline \multirow[t]{2}{*}{ LTV (percent) } & 72.84 & 84.92 \\
\hline & $(15.55)$ & $(12.52)$ \\
\hline \multirow[t]{2}{*}{$\mathrm{LTV}=0.8$ (dummy) } & 0.179 & 0.169 \\
\hline & $(0.384)$ & $(0.375)$ \\
\hline \multirow[t]{2}{*}{ Conforming Share } & 0.842 & 0.927 \\
\hline & $(0.365)$ & $(0.260)$ \\
\hline
\end{tabular}




\section{High FICO Low FICO}

\begin{tabular}{lcc}
\hline Documented Share & 0.375 & 0.453 \\
FICO & $(0.484)$ & $(0.498)$ \\
& 783.6 & 617.1 \\
Subprime Share & $(14.96)$ & $(35.79)$ \\
& 0.00896 & 0.345 \\
HPI Appr. (Two-year Log Difference) & 0.252 & 0.225 \\
& $(0.141)$ & $(0.145)$ \\
HPI Vol & 0.00789 & 0.00768 \\
& $(0.00319)$ & $(0.00323)$ \\
Log(Real Income) MSA & 10.52 & 10.46 \\
& $(0.237)$ & $(0.213)$ \\
Real Income (2005 Dollars) & 37990.5 & 35586.8 \\
& $(9860.2)$ & $(7968.9)$ \\
UR(County) & 4.781 & 5.057 \\
\hline Observations & $(1.235)$ & $(1.315)$ \\
\hline
\end{tabular}

